Montana State Library

30864100348609 


\title{
An integrated stream restoration and native fish conservation strategy for the Blackfoot River Basin
}

\author{
A report to \\ the stakeholders of the \\ Blackfoot River Fisheries Restoration Initiative
}

By

Ron Pierce, Ryen Aasheim and Craig Podner Montana Fish, Wildlife and Parks

3201 Spurgim Road

Missoula, Montana 59804

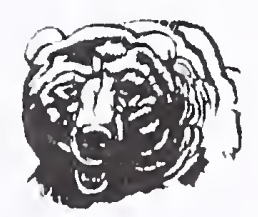

April 2005 



\section{ACKNOWLEDGEMENTS}

This restoration and conservation strategy was prepared in cooperation with the Blackfoot Challenge with funding from the Chutney Foundation and the Renewable Resource Program of the Montana Department of Natural Resource and Conservation. We extend special thanks to Tina Burnd-Cohen, Brian McDonald and Bob Anderson with the Blackfoot Challenge for assisting in the outline and development of the plan. For their review and comments, we also thank Don Peters and Fred Lurie with the Big Blackfoot Chapter of Trout Unlimited, Greg Neudecker with the U. S. Fish and Wildlife Service, Laura Burns with the U.S. Forest Service, Ladd Knotek, Pat Saffel, Brad Shepard, Glenn Phillips and Bob Snyder with the Montana Fish, Wildlife and Parks. 
Digitized by the Internet Archive in 2015 
ACKNOWLEDGEMENTS.................................................... 2

TABLE OF CONTENTS .................................................. 3

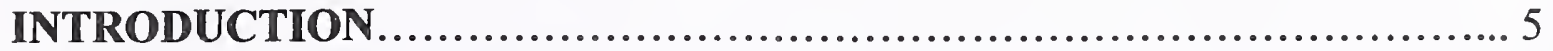

STUDY AREA......................................................... 6

RESTORATION CONCEPTS............................................ 6

FISHES OF THE BLACKFOOT WATERSHED..................................... 9

Recreational (non-mative) salmonids of the Blackfoot Watershed..... 9

Brown trout ................................................... 10

Rainbow trout ................................................ 10

Brook trout ................................................... 10

NATIVE TROUT CONSERVATION AND RECOVERY.................. 12

Bull trout recovery areas - core areas and proposed critical habitat.... 12

Bull trout recovery/recreational conflict areas............................ 13

Westslope cutthroat trout conservation..................................14

Native species management areas...................................... 16

Native species conservation areas...............................16

Native species management areas................................. 17

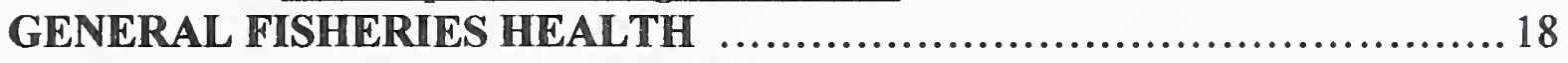

Fisheries impairments of the Blackfoot River........................ 18

Tributary impairments..............................................21

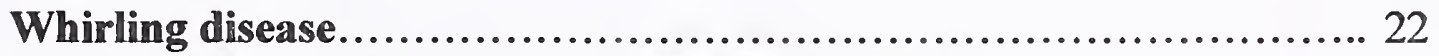

PROCEDURES: RESTORATION PRIORITIZATION .....................24

Prioritization strategy .............................................. 24

Prioritization shortcomings......................................... 26

Drought prioritization.............................................. 27

RESULTS PART I: SUMMARY ........................................ 28

High priority streams.............................................. 29

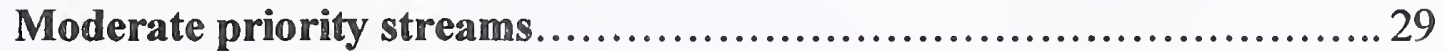

Low priority streams........................................... 31

RESULTS PART II: TRIBUTARY DESCRIPTIONS......................33

High priority streams ............................................... 33

Moderate priority streams........................................... 70

Low priority streams.............................................. 102

RESTORATION MONITORING PROTOCALS.......................... 134

APPENDICES ............................................................ 138 


\section{TABLE OF CONTENTS (cont.)}

\section{List of Figures}

Figure 1. Landownership of the Blackfoot Watershed...........................6 6

Figure 2. Distribution of five salmonid species................................. 11

Figure 3. Bull trout core areas watershed (excluding the

Clearwater River watershed) and proposed critical habitat.................. 12

Figure 4. Bull trout recovery/recreational conflict areas........................... 14

Figure 5. Westslope cutthroat trout genetic maps with sample locations and percent genetic composition....................................... 15

Figure 6. Native species management areas for the Blackfoot River Watershed.... 17

Figure 7. Percent trout species composition for five reaches of the Blackfoot River....................................................20

Figure 8. General whirling disease distribution map.............................23

Figure 9. Histograms and cumulative percentage curves used to develop prioritization categories............................................... 25

Figure 10. Dewatered streams of the Blackfoot River Watershed..................26

Figure 11 . High priority streams.............................................. 28

Figure 12. Moderate priority streams.........................................3

Figure 13. Low priority stream.............................................. 31

\section{List of Tables}

Table 1. Anthropogenic fisheries impairments for 108 water bodies............... 22

Table 2. Forty-one streams on the 303(d) list prioritized by total biological rank...27

Table 3. Types and methods of monitoring..................................... 136

Table 4. Restoration categories, the type of monitoring appropriate to the category and methods of conducting restoration monitoring on fisheries projects........................................................ 136

Table 5. Prioritization matrix.................................................. 141

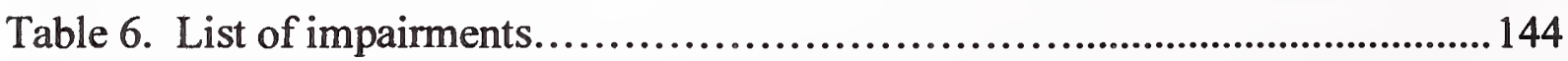

Table 7. Water bodies sorted by total restoration priorities..........................149

Table 8. Water bodies sorted by biological priorities............................. 149

Table 9. Water bodies sorted by native species priorities........................ 150

Table 10. Dewatered streams sorted by biological priority....................... 151

Table 11. Dewatered stream list for the Blackfoot River Watershed............... 152 


\section{INTRODUCTION}

The Blackfoot Watershed encompasses 2,320 square miles of biologically rich and diverse lands in western Montana. The Blackfoot River system provides important habitat for a number of fish species, including imperiled native fish, critical riparian habitats for wildlife and high quality public recreational opportunities.

Through the cooperation of public agencies, conservation groups and private individuals, the Blackfoot Watershed has become a regional leader in field of fisheries restoration. Since the fisheries restoration initiative began in 1990, projects have become more inclusive of native fish, water quality, instream flows, landscape protection and many other watershed-level concerns. As a result, the need for a more clearly defined comprehensive watershed-wide restoration strategy has increased. This need originates from 1) an expanded number (and scope) of watershed interest groups, 2) a cadre of recent federal, state and regional fisheries management directives, 3) the development of total maximum daily load (TMDL) plans, and 4) the initiation of a watershed-level longterm drought planning process. While undertaking these various programs, it became increasingly apparent that consolidating stream restoration, native fish recovery and other supporting activities was necessary. Our rationale for generating this report was that by integrating all fisheries-related restoration programs into a single guiding strategy, the Blackfoot Cooperators could better meet a common suite of conservation goals.

The purpose of this planning document is develop a cohesive restoration strategy that directs stakeholder involvement to common priorities involving the needs of native and recreational fisheries, improvements to water quality and instream flow. To this end, the plan provides a comprehensive, native fisheries-based, priority-driven template for restoration projects and expands upon the gains of the existing Blackfoot River Restoration Program. Specific objectives of this report are to:

1. Provide a planning strategy to guide restoration activities of the Blackfoot Challenge, Montana Fish, Wildlife and Parks, US Fish and Wildlife Service, Big Blackfoot Chapter of Trout Unlimited and other restoration partners.

2. Integrate the TMDL program, and the Blackfoot River water conservation and in-stream flow plans into the framework of a restoration strategy with emphasis on the recovery and conservation of native fishes.

3. Expand on an existing fisheries-based stream restoration prioritization ranking system (FWP 2002).

4. Re-prioritize and describe all FWP currently inventoried streams based on the expanded ranking system.

5. Outline monitoring strategies and protocols to promote consistent and adequate monitoring for planning and assessing restoration project effectiveness.

Within a context of fisheries conservation, this report addresses three primary categories of restoration: 1) FWP identified stream restoration issues; 2) stream dewatering; and 3) restoration opportunities identified through the Montana Department of Environmental Quality TMDL program. Strategies describe herein will in turn be used to help direct restoration efforts, secure implementation funding and coordinate stakeholder involvement. 


\section{STUDY AREA}

The Blackfoot River, located in west central Montana, begins at the junction of Beartrap and Anaconda Creeks, and flows west 132 miles from its headwaters near the Continental Divide to its confluence with the Clark Fork River in Bonner, Montana (Figure 5). Mean annual discharge is 1,596 cubic-feet-per-second (cfs).

The Blackfoot River is one of twelve renowned "blue-ribbon" trout rivers in Montana with a 1972 appropriated "Murphy" in-stream flow water right of $700 \mathrm{cfs}$ at the USGS Bonner gauging station. Montana Fish, Wildlife and Parks manages fisheries of the Blackfoot River and tributaries for a diversity of self-sustaining "wild trout" populations.

This river system drains a 2,320 square mile watershed through a 3,700-mile stream network, of which 1,900 miles are perennial streams capable of supporting fishes. The physical geography of the watershed ranges from high-elevation glaciated alpine meadows, timbered forests at the mid-elevations, to prairie pothole topography on the valley floor. Glacial landforms, moraine and outwash, glacial lake sediments and erratic boulders cover the floor of the entire Blackfoot River valley and exert a controlling influence on the habitat features of the Blackfoot River and the lower reaches of most

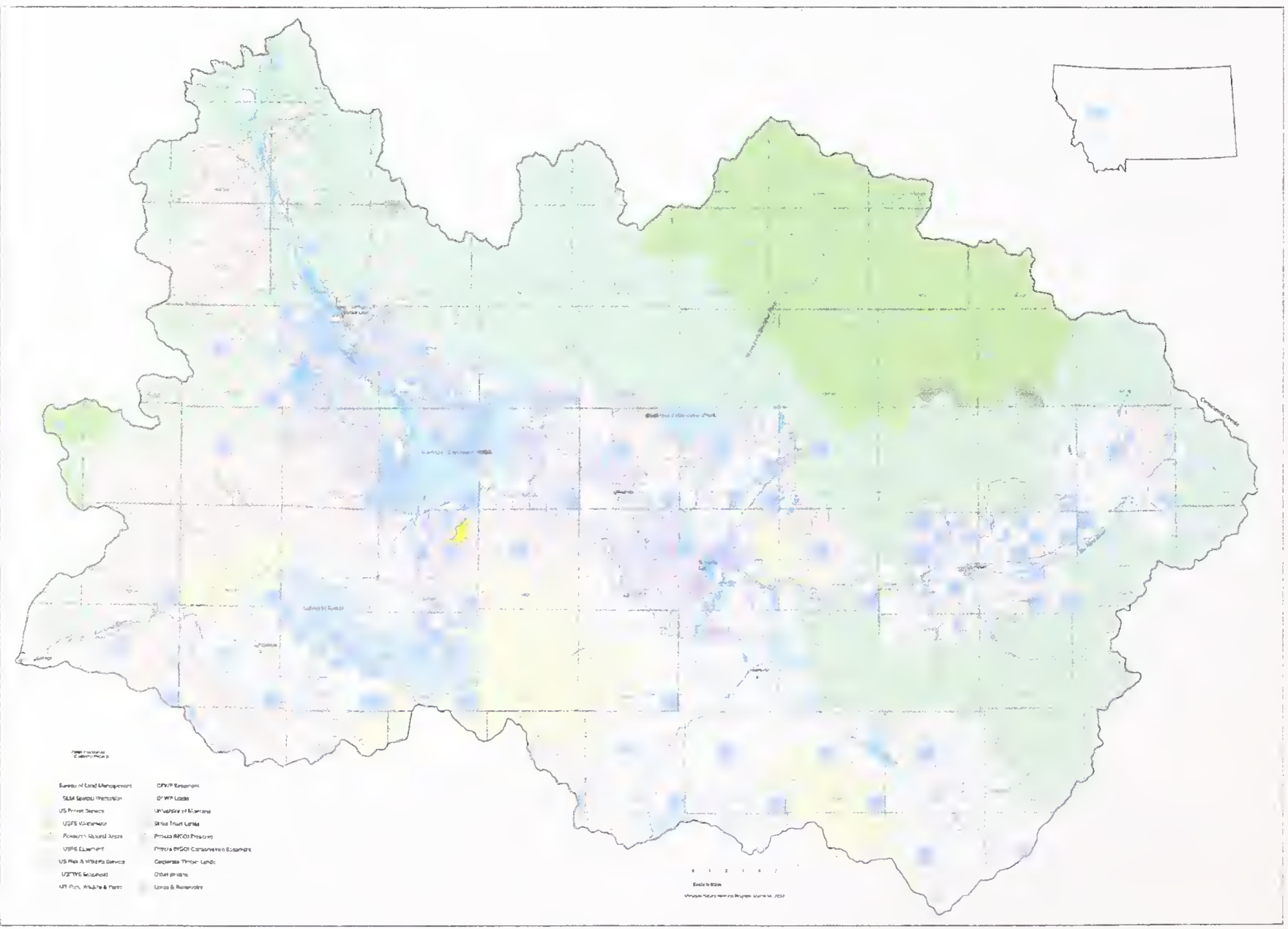

Figure 1. Landownership map for the Blackfoot River Watershed. 
tributaries. The Blackfoot River is a free flowing river to its confluence with the Clark Fork River where Milltown dam, a run-of-the-river hydroelectric facility, has blocked upstream fish passage since 1907.

Current land ownership in the Blackfoot watershed is $42 \%$ National Forest, $25 \%$ private ownership, 19\% Plum Creek Timber Company, 7\% State of Montana, and 6\% Bureau of Land Management. In general, public lands and large tracts of Plum Creek Timber Company properties comprise large forested tracts in mountainous areas of the watershed, while private lands occupy the foothills and lower valley areas. Traditional land-use in the basin includes mining, timber harvest, agriculture and recreation activities, all of which have contributed to habitat degradation or fish population declines. Of 108-inventoried water bodies, over 90 have been variously altered, degraded or otherwise identified as fisheries-impaired since inventories began in 1989. Restoration has been directed to 43 of these streams. The majority of habitat degradation occurs on the valley floor and foothills of the Blackfoot watershed and largely on private agricultural ranchlands. However, problems also extend to industrial forests, mining districts, and state and federal public lands.

\section{RESTORATION CONCEPTS}

The Blackfoot River watershed possesses a variety of wild trout, as well as cooland warm-water fishes. Within the watershed, the distribution of fishes is longitudinal - a pattern in which species richness increases in the downstream direction and with increasing stream size. In contrast to this general distribution, imperiled native fish (fluvial bull trout and fluvial westslope cutthroat trout) occupy large areas of the watershed. These fish spawn often in discrete areas and rear in small streams high in the watershed before moving down to the larger, more productive streams where they grow to maturity. These broad areas of native fish use overlap at the low elevations with over 20 other species, including important non-native sport fish such as rainbow trout and brown trout.

With few exceptions, the life histories of wild trout of the Blackfoot River involve tributaries. Based on these inter-relationships, community richness and population densities of fishes in the mainstem Blackfoot River closely reflect the number and quality of nearby tributaries. Biotic relationships between the Blackfoot River and tributary system also vary by river reach. Some reaches of the Blackfoot River support naturally (and seasonally) harsh environments, while others support few (if any) functional tributaries. The subtle adaptations native fish possess (including whirling disease resistance) conform to the (spatial and temporal) environmental variability (and natural extremes) of the Blackfoot River/tributary system. However, the extensive use of the watershed and specialized adaptations also make imperiled native fish of the Blackfoot River highly vulnerable to adverse (human-related) alterations to aquatic (e.g. tributary) ecosystems.

Since hatchery stocking of rainbow trout ceased in 1979, Montana Fish, Wildlife and Parks (FWP) has managed stream-dwelling salmonids of the Blackfoot River under the wild trout philosophy - a management philosophy that relies upon natural reproduction of wild fish. Attaining quality habitat and stream connectivity provide the basis of this management philosophy. Quality stream habitat is defined as a stream 
possessing water of sufficient quantity and quality where an arrangement of physical channel features provides food, cover (security) and space in an environment that allows a population to thrive. Stream connectivity provides the mechanism for fish to move among streams or stream reaches and to complete their life cycle and use a variety of habitats. When attempting to correct fisheries-impairment (e.g. habitat) on streams, properly identifying and correcting habitat-related limiting factors is essential to successfully restoring stream-dwelling wild trout. Limiting factors are defined as any factor that inhibits or limits the population below its full potential. This concept of managing for wild trout, focusing on native fish, restoring and connecting habitats, and correcting other human-induced limiting factors forms the general foundation of the Blackfoot River fisheries restoration initiative. These methods, where properly implemented, have consistently led to expanded wild trout populations (including native fish) in waters of the Blackfoot River.

Restoration planning, at a basic level, involves the biogeography of fishes, an understanding of fisheries (e.g. habitat) impairment, and the role that stakeholders (e.g. private landowners and the angling public) play in restoration outcomes. At a secondary level, the methods and outcomes of restoration must further consider 1) stream potential, 2) the relationships of project scale (i.e. stream-reach, stream and watershed) to the problem, 3) a recognition of tradeoffs, 4) indirect and/or downstream benefits of restoration actions, and 5) uncertainty (i.e. risk) of restoration outcomes.

Reducing uncertainty of outcomes, above all, requires firm commitment of cooperating parties to success. Generating sufficient project information on which to base restoration decisions is also essential. Project information involves recognizing not only the sources of impairment, but also reasonable assessments of biological (i.e. fisheries) outcomes. Obtaining this information usually involves: 1) establishing a thorough pre-project (habitat and fish populations) baseline; 2) understanding life-history, habitat associations and limiting factors related to target and, in some cases, non-target species; 3) identifying clear and attainable restoration goals and objectives; 4) developing realistic time-frames necessary for project and species recovery; 5) recognizing an ability to correct up-and downstream limiting factors; and 6) developing post-project monitoring protocols through recovery phases to ensure the projects meet their objectives. A willingness to modify restoration methods based on monitoring results is also important.

Restoration practices must also conform to the "trust" responsibilities of several local, state, and federal natural resource and permitting agencies. Considerations of offsite concerns may be germane to restoration outcomes and may involve downstream beneficial uses including improved water quality and quantity, and/or recruitment of recreational species to the Blackfoot River. Less predictable outcomes may result from the influences of exotic fishes, diseases and perhaps climate change on some projects.

As final outcomes, restoration projects must be consistent with ecologically sound and sustainable practices, contribute to conservation of high quality aquatic habitat and protect native aquatic species. As outlined below, several restoration-related plans can help guide restoration practices and the recovery and conservation of native fishes. The intent of these plans has been integrated into the framework of this strategy.

- Restoration plan for bull trout in the Clark Fork River Basin and Kootenai River Basin Montana (MBTRT 2000), 
- Draft Recovery Plan for the Bull Trout and Proposed Critical Habitat (USFWS 2002).

- A Hierarchical Strategy for Prioritizing the Restoration of 83 Impaired Tributaries of the Big Blackfoot River (Pierce et al 2002b).

- Westslope Cutthroat Trout Status Review (Shepard et al. 2003).

- Region 2 Native Salmonid Management Guidelines, Montana Fish, Wildlife and Parks, Missoula

Several additional research projects and FWP restoration-related studies completed in the Blackfoot River watershed (Appendix A and literature-cited sections) also provide relevant information.

\section{FISHES OF THE BLACKFOOT WATERSHED}

There are currently 12 native fish species and 13 known non-native fish species in the Blackfoot Watershed, as well as several hybrid salmonids. Native species of the Blackfoot Watershed are bull trout (Salvelinus confluentus), westslope cutthroat trout (Oncorhynchus clarki lewisi), mountain whitefish (Prosopium williamsoni), pigmy whitefish ( $P$. coulteri), longnose sucker (Catostomus catostomus), largescale sucker $(C$. macrocheilus), northern pikeminnow (Ptychocheilus oregonensis), peamouth (Mylocheilus caurinus), redside shiner (Richardsonius balteatus), longnose dace (Rhinichthys cataractae) slimy sculpin (Cottus cognatus) and mottled sculpin (C. bairdi). Non-native species include rainbow trout $(O$. mykiss), kokanee $(O$. nerka), Yellowstone cutthroat trout $(O$. clarki bouvieri), brown trout (Salmo trutta), brook trout (Salvelinus fontinalis), arctic grayling (Thymallus arcticus), white sucker (C. commersoni), fathead minnow (Pimephales pomelas), northern pike (Esox lucius), brook stickleback (Culaea inconstans), pumpkinseed (Lepomis gibbosus), largemouth bass (Micropterus salmoides) and yellow perch (Perca flavescens).

Compared with other families of fishes, stream-dwelling salmonids of the Blackfoot River receive management emphasis. Emphasis on salmonids relates to their "sensitive" status and popular sport fisheries value. As a family of fishes, salmonids (and native trout specifically) can also be compared to the "canary in the coal mine," meaning they are very sensitive to changes in water quality, especially increases in sediment and water temperature. As indicators of cold and clean water, measures to restore natural conditions suitable to salmonids also provide benefits to sympatric non-salmonids - those species that receive less management emphasis but that require similar natural environments.

Most salmonids in the Blackfoot River (rainbow trout, brown trout, westslope cutthroat trout, bull trout and mountain whitefish) exhibit fluvial (or migratory) lifehistories, whereas tributaries support both migratory and stream-resident populations. Migratory fish are hatched in tributaries where they rear before migrating to a river where they grow to maturity before returning to natal tributaries to spawn. Migratory fish require connectivity. Stream resident fish exhibit less movement and spend their entire life in small streams. Enhancing and maintaining migratory forms is desirable because more and variable habitats are needed, thus allowing more fish in a population and greater resistance and resilience to stochastic events. Connectivity and migratory forms 
also increase the likelihood of and provide a source of naturally refounding extirpated populations. This increases probability of long-term survival of the species.

\section{Recreational (non-native) salmonids of the Blackfoot Watershed}

Several introduced fishes (e.g. brown trout, rainbow trout and brook trout) of the Blackfoot River environment are managed as sport fisheries, while also providing harvest opportunities.

Brown trout: European brown trout, introduced to North America in the $1880 \mathrm{~s}$, include a diversity of life-history forms. The mixing of various European stocks brought the basis of genetic diversity and potential for rapid naturalization of self-sustaining populations of brown trout across the continent. Brown trout rapidly became established and quickly replaced native trout in large rivers of the West. Brown trout now support popular sport fisheries in many rivers including the Blackfoot River. In the Blackfoot watershed, brown trout tend to dominate medium-sized, low-elevation tributaries that provide undercut banks and abundant cover. Brown trout co-exist with other salmonids in the larger river reaches where sufficient habitat complexity creates a diversity of niches. Brown trout inhabit $\sim 15 \%$ of the perennial stream system with a distribution that extends from the Landers Fork down the length of the Blackfoot River and into the lower foothills of the tributary system tributaries (see distribution map on Figure 2). As a species, brown trout co-evolved with the parasite Myxobolus cerebralis. As a result, brown trout possess a higher level of natural resistant to whirling disease than other salmonids.

Rainbow trout: Rainbow trout, a renowned sportfish, has been introduced into cold-water habitats worldwide. In western Montana, rainbow trout were brought inland from coastal and other areas of western North America beginning in the late 1800s. Since the implementation of wild trout management, the distribution of rainbow trout in the Blackfoot watershed has diminished, with the species no longer present in the upper Blackfoot River. Stream-dwelling rainbow trout currently inhabit the lower mainstem Blackfoot River and reproduce in the lower portions of the larger tributaries. Rainbow trout occupy $\sim 10-15 \%$ of the perennial streams at the lower elevation of the Blackfoot watershed (see distribution map on Figure 2). They dominate the lower river reaches but also are established in some lakes, reservoirs and private ponds. Rainbow trout are highly susceptible to whirling disease, which is expanding within the range of streamdwelling rainbow trout in the Blackfoot Watershed. This escalation of whirling disease corresponds with a trend of declining densities for wild rainbow trout in the mainstem Blackfoot River.

Brook trout: Brook trout, like all charr in the genus Salvelinus (including bull trout), are known for their adaptation to cold water. However, unlike other charr, brook trout are also tolerant of warmer waters. Unlike bull trout, brook trout are also more tolerant of higher sediment levels and are thus better able to reproduce in streams of impaired condition. Brook trout can maintain populations in isolation, while bull trout generally require stream connectivity. Brook trout were brought to the inland American West from northeastern 

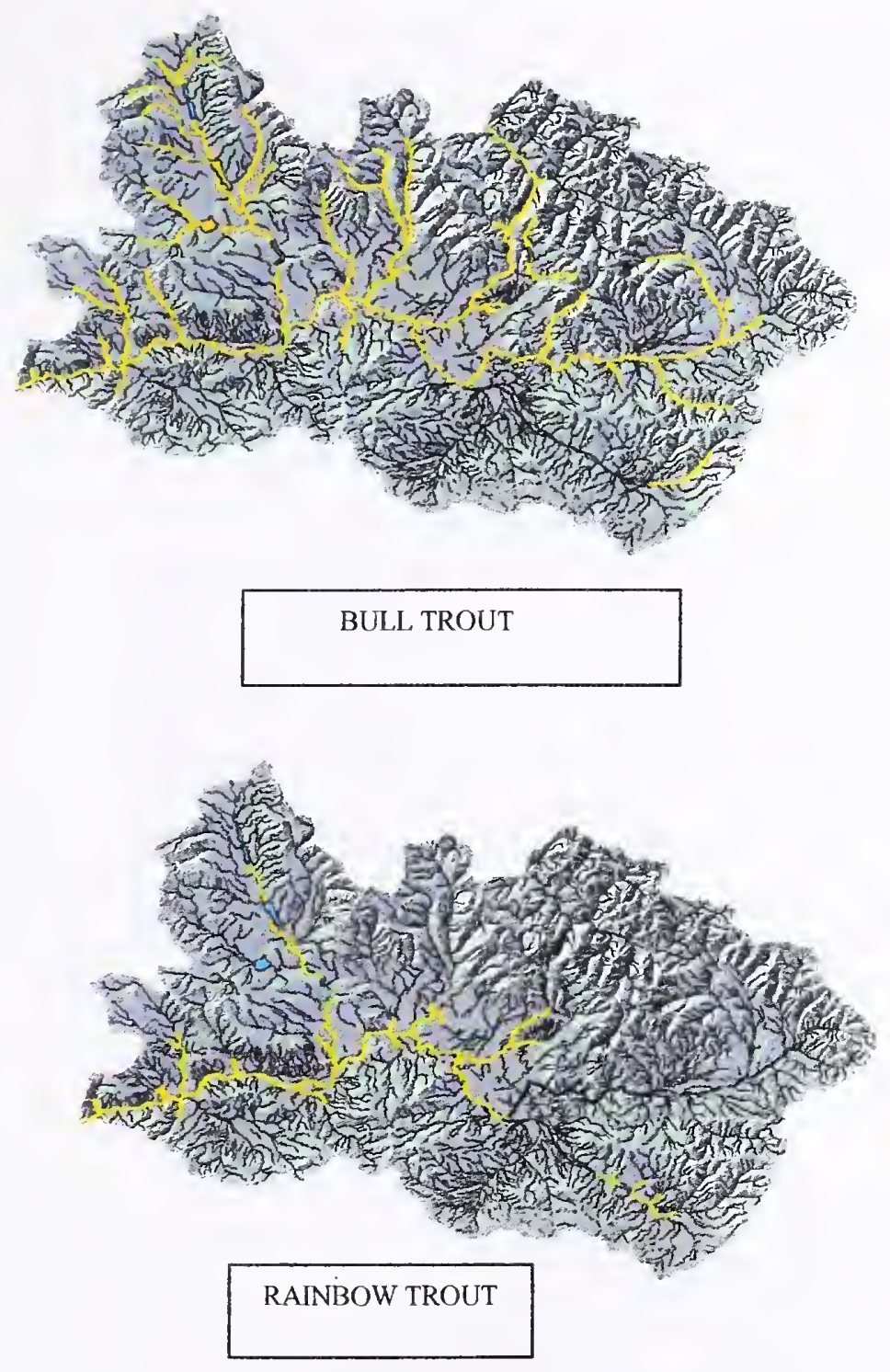

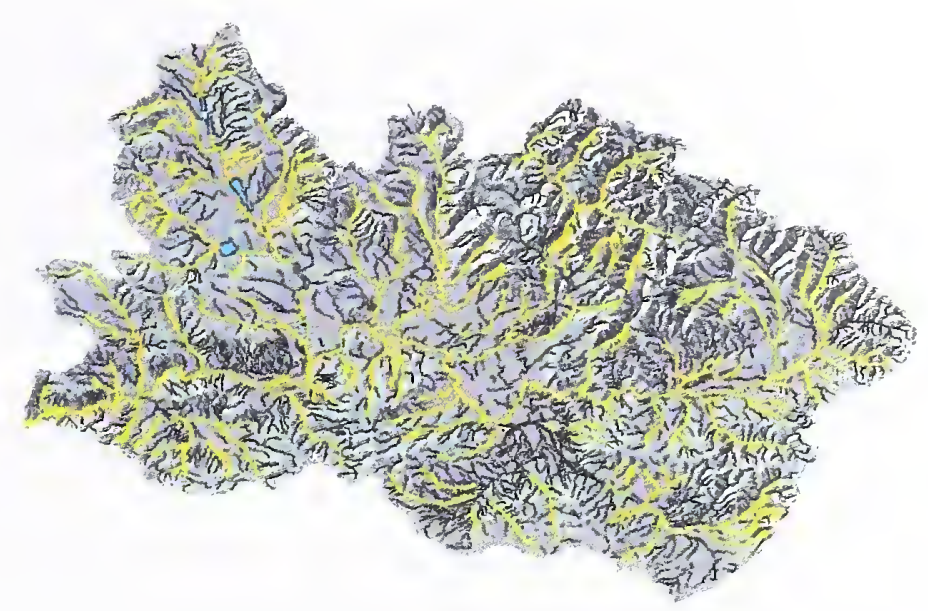

WESTSLOPE CUTTHROAT TROUT

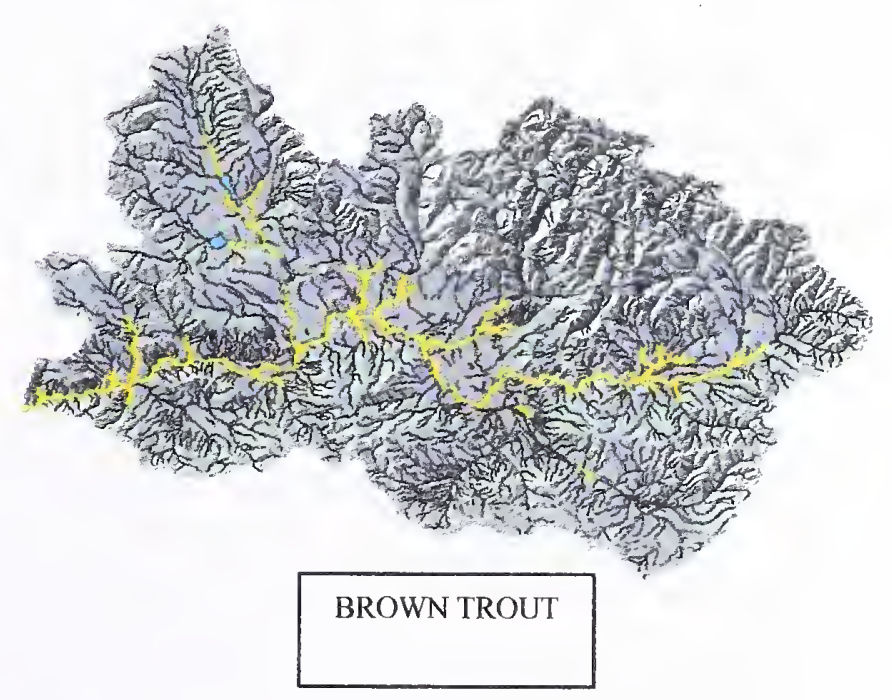

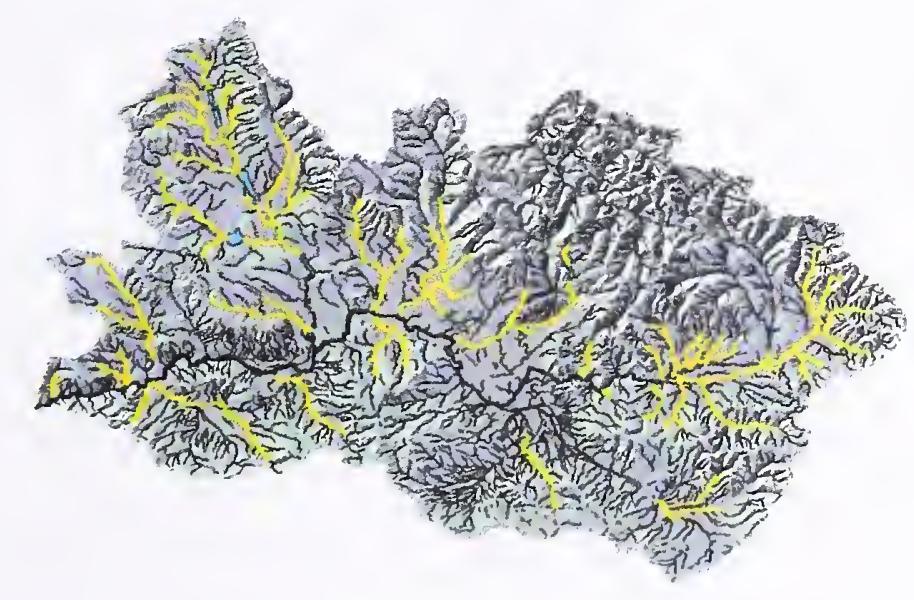

BROOK TROUT

Figure 2. Distribution map of five salmonid species in the Blackfoot River basin. 
North America for sportfishing and subsistence between 1920 and 1950. Brook trout have vastly increased their distribution and abundance and now pose a threat to native westslope cutthroat trout and bull trout and have replaced populations of both species in certain waters. Resident brook trout are widely distributed in tributaries of the Blackfoot Watershed, but are rare in the mainstem Blackfoot River below the Landers Fork tributaries (see distribution map on Figure 2). Brook trout are considered vulnerable to whirling disease.

\section{NATIVE TROUT CONSERVATION AND RECOVERY}

\section{Bull trout recovery areas - core areas and proposed critical habitat}

Bull trout is a Montana species of special concern and threatened under the Endangered Species Act (ESA). The recovery of bull trout is a fisheries priority under both State FWP and Federal USFWS programs in the Blackfoot Watershed. Bull trout inhabit $\sim 125$ miles of the Blackfoot River main stem. Bull trout are especially vulnerable to increased water temperatures and sediment loads, changes in flow regimes, blocked migration routes and non-native trout like brook trout. Densities of bull trout are very low in the upper Blackfoot River, but increase downstream of the North Fork at river mile (rm) 54 . Outside of the Clearwater River drainage, bull trout occupy $\sim 25 \%$ of the drainage or $\sim 355$ miles of stream (see distribution map on Figure 2). Most bull trout

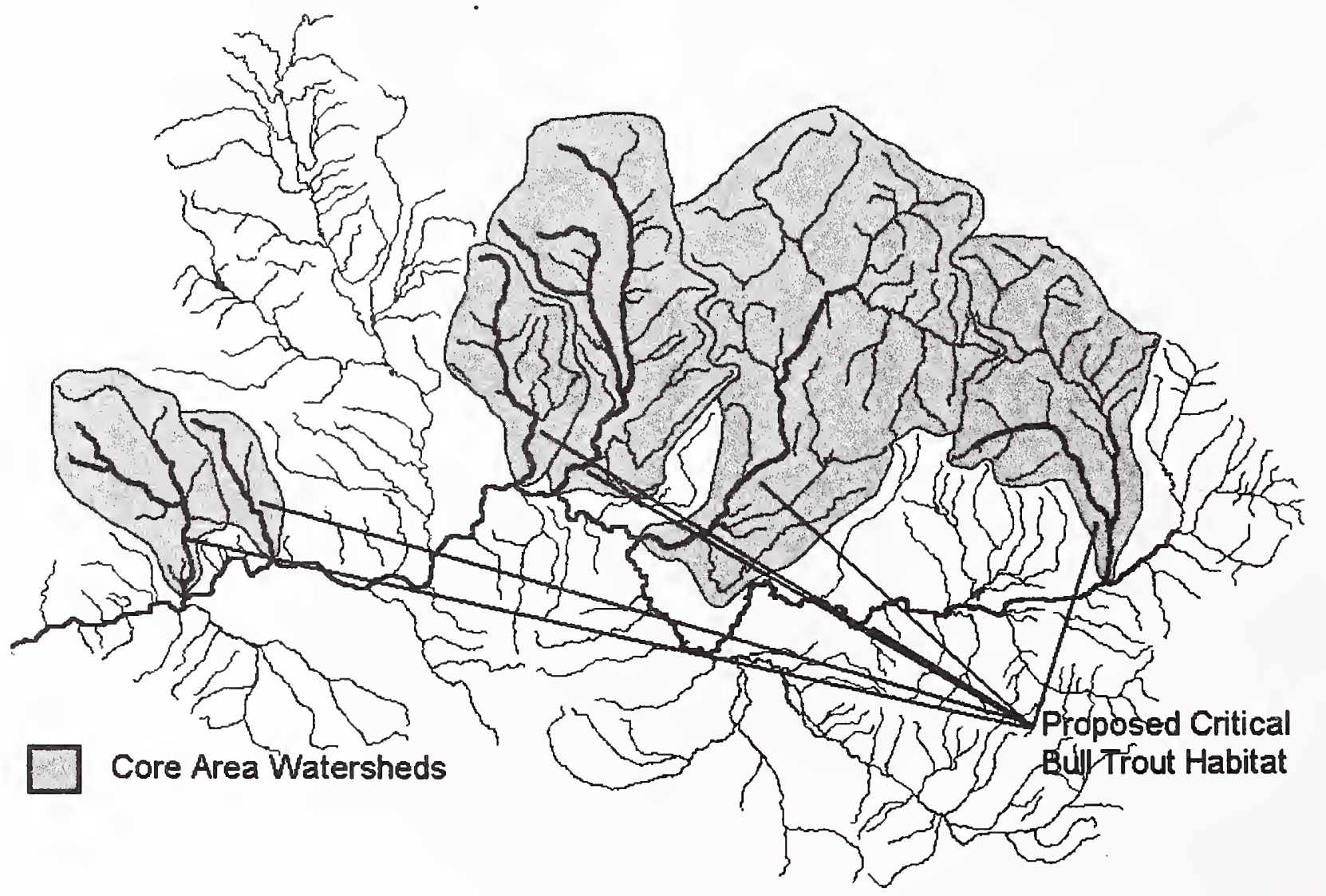

Figure 3. Bull trout core area watersheds (excluding the Clearwater River drainage) and proposed critical bull trout habitat. 
spawning streams (Gold Creek, Dunham Creek, Monture Creek, Copper Creek, and the North Fork of the Blackfoot River) support fluvial fish, although some streams (Poorman, Cottonwood and Belmont Creeks) seem to support predominately resident bull trout. Adult migratory bull trout distribution is generally tied to the larger, colder streams north of the Blackfoot River and larger, more productive river reaches. Fluvial bull trout reproduce in only a few discrete groundwater-fed spawning sites and seek cold-water refugia during periods when the river is warm $\left(>60^{\circ} \mathrm{F}\right)$. Juvenile bull trout also seek small, non-spawning tributaries presumably for cold-water refugia, foraging and predator avoidance, some of which are located in the Garnet Mountains,

Bull trout recovery focuses on primarily core area watersheds and proposed critical habitat (Figure 3) (MBTRT 2000, USFWS 2002). To assist with bull trout recovery in the Blackfoot Watershed, the Montana Bull Trout Recovery Plan (MBTRT 2000) established the following recovery goals: 1) maintain self-reproducing migratory fish in the Blackfoot River with access to tributary streams and spawning in all core area watersheds; 2) maintain the population genetic structure throughout the watershed; 3) maintain and increase the connectivity between the Blackfoot River and its tributaries; 4) establish a baseline of redd counts in all drainages that presently support spawning migratory bull trout; and 5) maintain a count of a least 100 redds or 2,000 individuals in the Blackfoot drainage with an increasing trend thereafter (MBTRT 2000). In 2002, the USFWS designated proposed critical habitat and developed a draft recovery plan. The proposed critical habitat designation included the mainstem Blackfoot River and all mainstem tributaries of all core area watersheds. The draft recovery plan outlined measures needed to help remove bull trout from the ESA list, similar to the Montana Bull Trout Recovery Team (USFWS 2002).

In addition to State and Federal recovery plans, several research and restorationrelated reports further contribute to bull trout recovery planning in the Blackfoot River Watershed (Appendix Exhibit A). These plans generally outline: 1) the relationships of bull trout to clean, cold, connected and complex habitats; 2) life-history relationships with spawning and non-spawning tributaries and river reaches; and 3) ecological risks related to adverse land use practices, as well as interactions of non-native fishes. For restoration activities in bull trout habitat (e.g. core area watersheds), recovery plans should be considered on a stream specific basis, in conjunction with pertinent recovery plans, and in consultation with State biologists during initial project planning phases.

\section{Bull trout recovery - recreational conflict areas}

Based on recreational-related risks to bull trout recovery, FWP recently identified bull trout recovery - recreational conflict areas (Figure 4). These conflict areas refer to biologically critical sites (key spawning, rearing and staging areas, important migration corridors and areas of thermal refugia), which overlap with recreational developments, areas of increased angler pressure and where illegal bull trout harvest is a concern. Concern over conflict areas also relate to: 1) large increases in angling pressure in bull trout recovery areas; 2) the documented inability of most anglers to identify bull trout; 3 ) continued illegal harvest of bull trout; and 4) expanded recreational developments in critical recovery areas. Recent declines in adult bull trout densities and population size compound these concerns. Integrating recreational conflict areas into this plan would lead to a more programmatic and conservation-based management philosophy by 
resource management agencies and other stakeholders involved in bull trout recovery. Additional special fishing regulations may also be necessary to protect native salmonids in these areas.

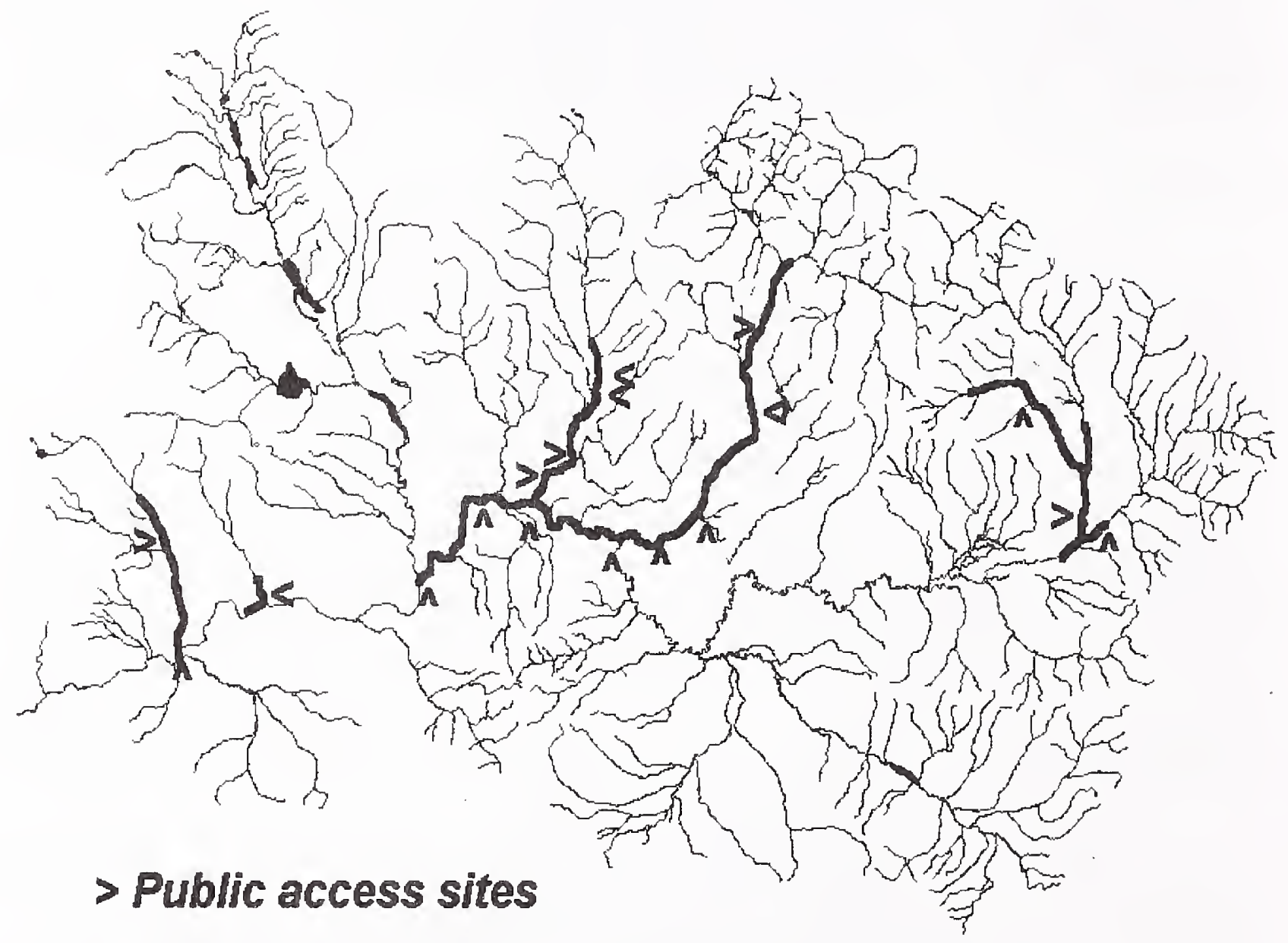

Figure 4. Bull trout recovery/recreational conflict areas for the Blackfoot Watershed.

\section{Westslope cutthroat trout conservation}

Westslope cutthroat trout (WSCT), a species of special concern in Montana, has declined over much of their historic range within the last century. These declines are more pronounced in the Missouri River drainage than the upper Columbia River drainages (Shepard et al. 2003). Reasons for the decline include habitat loss and degradation, genetic introgression with introduced rainbow trout and Yellowstone cutthroat trout, over-harvest, and competition with introduced brook trout and brown trout. In the Blackfoot Watershed, WSCT occupy $\sim 93 \%$ of historical range, compared with $\sim 39 \%$ of occupied historical range statewide. The Blackfoot River also supports one of the larger fluvial meta-populations of WSCT (upper drainage) in Montana, but at population abundance well below habitat capacity (Shepard et al. 2003).

The Blackfoot River watershed (outside of the Clearwater Drainage) supports a nearly basin-wide distribution of WSCT with $86 \%$ ( 85 of 98) of surveyed fish-bearing tributaries containing WSCT (Figure 2). Many additional tributaries on public (USFS) lands also contain WSCT. Streams lacking WSCT are either impaired headwater streams 
or degraded spring creeks. The densities of WSCT usually decrease in the downstream direction. These longitudinal decreases typically relate to adverse habitat changes, losses to irrigation ditches, barriers to movement, natural dewatering and the interactions with non-native fishes.

WSCT stocks include migratory (fluvial) and stream resident fish. Fluvial fish have a sympatric resident component. Both stream resident and fluvial WSCT rely on high quality tributary habitats for spawning, rearing and over-wintering. Stream resident fish can also maintain populations in isolation, occupying less than one mile of perennial stream in some cases. Stream connectivity and access to the Blackfoot River is also necessary for fluvial WSCT to complete their life cycle. Fluvial WSCT spend early life stages in smaller streams and migrate to the river to mature where they grow to much

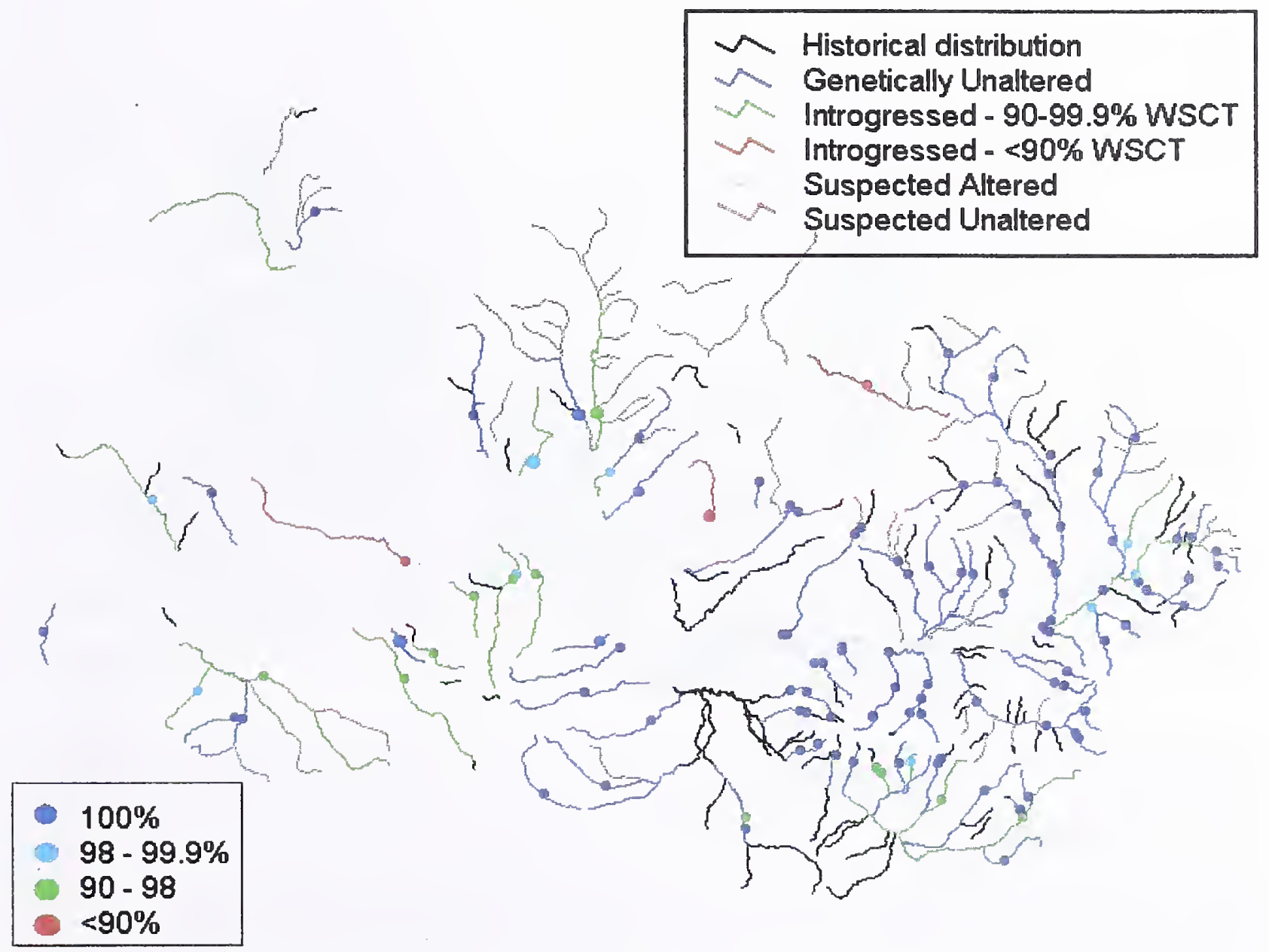

Figure 5. Westslope cutthroat trout genetics map with sample locations and percent genetic comnosition.

larger size than resident fish, before returning to natal tributaries to spawn.

WSCT genetic tests in the Blackfoot Watershed show a high degree of genetic "purity" over large areas, particularly in the upper watershed upstream of the confluence of the North Fork (Figure 5). Within this setting, a primary conservation strategy identified in the upper Blackfoot Watershed involves managing for metapopulation function and multiple life-history strategies (Shepard et al. 2003). This conservation strategy involves managing both stream resident and fluvial WSCT. Managing metapopulations of fluvial fish not only involves maintaining main stem connectivity of 
the Blackfoot River with spawning areas, but also: 1) reducing or eliminating controllable sources of anthropogenic mortality; 2) maintaining and restoring existing spawning and rearing habitats; and 3) managing lakes and private fish ponds with appropriate species. Although stream connectivity allows spawning migrations, season movements and complex life history strategies to persist, WSCT restoration strategies must also consider genetic integrity, as well as other ecological risks such as invasive species and diseases when considering restoring connectivity to isolated populations. A conservative WSCT conservation strategy should also entail maintaining an array of existing isolated populations of genetically "pure" WSCT as a measure against known and unknown ecological risks.

Ecological risks to WSCT conservation are generally complex and should be considered on a stream or reach specific basis. From a restoration and conservation perspective, planning should consider life-history expression, habitat capacity and availability, genetic composition, risks related to land use, potential interactions of nonnative species (e.g. brook trout and rainbow trout), as well as public expectations of recruitment to recreational fisheries. As with bull trout, the range of biological interactions and concerns for WSCT should be established in consultation with State agency fisheries biologist during the initial restoration planning process. This particularly applies where barriers, genetically pure isolet populations and potential for invasive species are involved

\section{Native Species Management Areas}

Native species management areas are general FWP designations representing a regional (FWP Region 2 administrative area) approach to native fish management in the Clark Fork watershed. In the Blackfoot sub-basin, the classification contains two major categories: 1) native species conservation areas; and 2) native species maintenance areas (Figure 6). Within each category, the following management implications are considered: 1) stocking and transplant policy; 2) fishing regulations; 3) watershed restoration activities; 4) land acquisitions by other agencies or conservation groups; 5) stream alterations and fish ponds; and 6) fishing access.

Native species conservation areas: In most cases, these are bull trout critical habitats and areas close in proximity to the headwaters, including spawning areas for fluvial fish. Conservation areas include: 1) streams that support native species, 2) a stable detectable bull trout population, 3) areas that tend to have genetically pure WSCT populations, or 4) areas where genetic composition can be improved by management. Conservation areas are critical to the long-term persistence of native species. Where native species will be the management emphasis, suppression or removal of introduced species will be considered to maintain populations in conservation areas. Guidelines and management strategies include:

1. Stocking of non-native species will not occur. The impacts of stocking on amphibians, reptiles and invertebrates if detrimental to native populations will be considered.

2. Fishing regulations will be tailored to encourage native species and discourage introduced species. 
3. These areas would be the highest priority for watershed restoration activities

4. These areas would be a priority for land acquisition and protection (e.g. conservation easements) by federal and state agencies.

5. Stream alteration permitting would strongly encourage the use of native material and natural stream function.

6. Fish species and strains permitted in private fishponds will only include those that are genetically compatible with the populations in source and receiving waters.

7. The biological consequences of additional fishing access sites on native populations would be heavily considered.

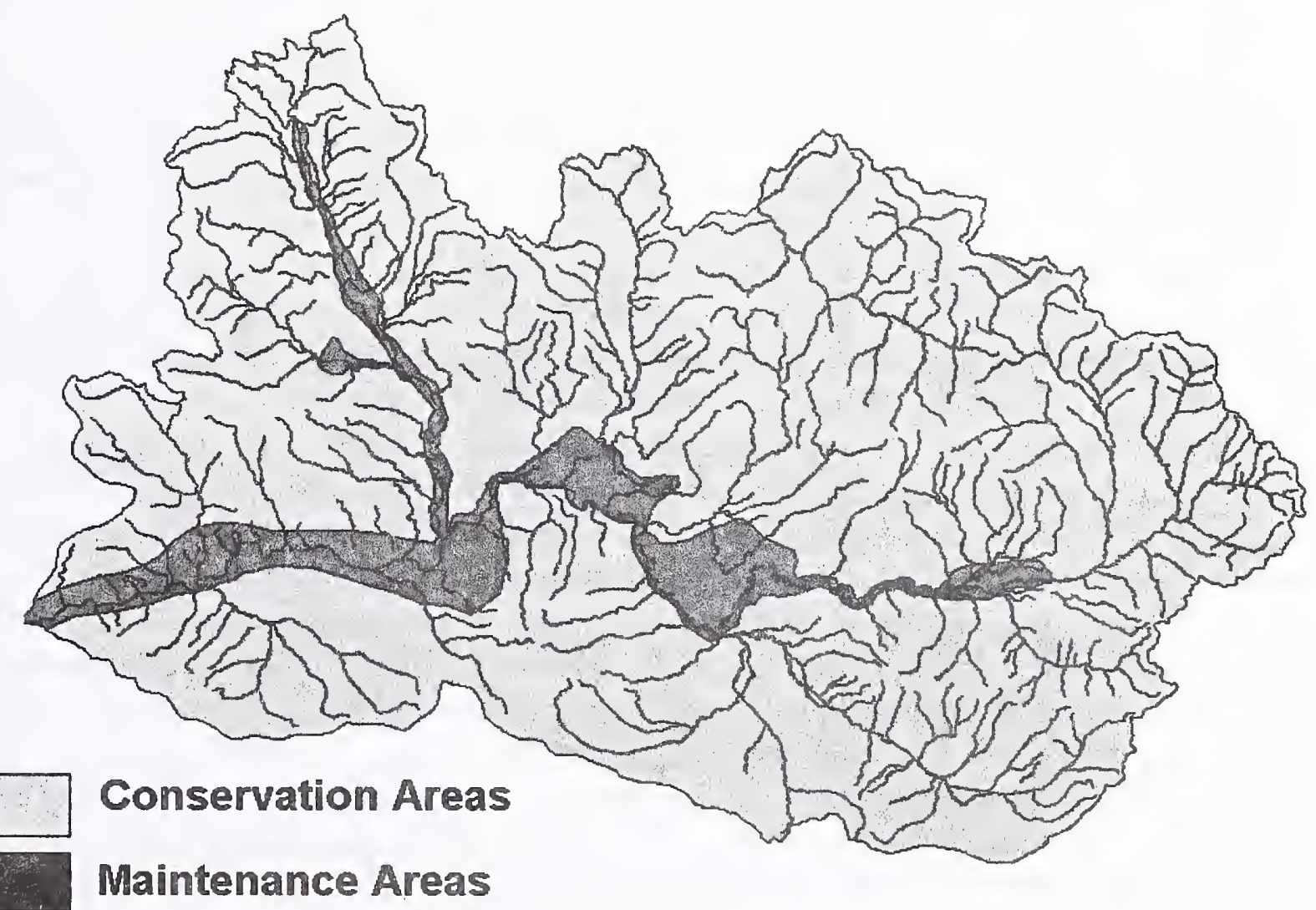

Figure 6. Native Species Management Areas for the Blackfoot River Watershed.

Native species maintenance areas: Maintenance areas of the mainstem support populations of fluvial WSCT or bull trout, but are predominately composed of non-native species (salmonids). Maintenance areas also include low elevation tributaries dominated by non-natives with only relic populations of native trout. These are areas where native species will be the management emphasis, but no active effort will be taken to remove or discourage introduced species. Guidelines and management strategies include:

1. Stocking of introduced species may occur if compatible with existing populations.

2. Fishing regulations will encourage native species. They will not necessarily discourage introduced species.

3. These areas are high priority for watershed restoration activities 
4. Land acquisition would be encouraged, but not as high a priority as native species conservation areas.

5. Non-native will be stocked in ponds if already present in the wild. Normal precautions will be taken to keep fish stocked in private ponds from contacting wild populations.

6. Fishing access would be prioritized based on angling opportunity and social need.

\section{GENERAL FISHERIES HEALTH}

\section{Fisheries impairments of the Blackfoot River}

The mainstem Blackfoot River is one of the most diverse and biologically complex rivers in western Montana. Unfortunately, large sections of the river support low densities of trout due to an array of natural and human-related factors. The natural complexity and limitations of the mainstem involve severe icing of the channel, low stream flows and drought prone areas, fine sediment accumulation and areas of limited secondary productivity. Human influences involve metals contamination, dewatering, barriers to movement (e.g. Milltown dam, irrigation diversions and many sub-standard road crossings), and areas of impaired water quality and extensive alteration of the tributary system and essential habitat components therein. Functional tributaries play essential roles in the life stages (migration, spawning and rearing) of all fluvial Blackfoot River fish. Altered and degraded tributaries generally inhibit movements and reduce spawning and rearing success, which contributes to suppressed populations and inadequate recruitment of multiple species over large areas of the Blackfoot River. The sum of these natural and human variables produces a diverse array of wild trout communities that vary in species composition and overall population densities among river reaches. Because of this variability, we consider the mainstem Blackfoot River on a reach-by-reach basis. Each reach has its own set of human-induced limiting factors that need to be corrected for populations to substantially improve.

Reach 1: Headwaters to Lincoln This reach has been evaluated since the 1970's, both before and after the collapse of the Mike Horse mine tailings dam. This ecological disaster sent contaminated mine tailings into the upper mainstem Blackfoot River. The acute and chronic effects of this contamination coincide with the collapse of WSCT in headwater areas. The tailings were partially contained by a series of wetlands, which prevented more serious contamination of the lower Blackfoot River. During the 1990s, a voluntary reclamation of patented mining claims was undertaken on ASARCO properties. Cleanup plans on the Helena National Forest are now being developed.

Below this area of contamination, the Blackfoot River supports WSCT, brown trout, brook trout and bull trout in low densities. In addition to mining contamination in the headwater, this reach lacks complexity in portions of the mainstem, naturally becomes dewatered downstream of Landers Fork and has localized tributary problems. Natural gas exploration is now occurring in tributaries of this reach. A low-level infection of whirling disease is also present in this reach.

FWP fish surveys in the early 1970s, before the collapse of the tailing dam, showed healthy WSCT numbers in the upper mainstem. After the dam collapse, WSCT numbers declined drastically. The biological impacts of this contamination continue to 
linger. In one sampling section (Pop's Place section) the point estimate for age $1+$ WSCT declined from $101 \mathrm{fish} / 1,000^{\circ}$ in 1971 to zero in 1999. In a downstream monitoring section (Flescher Pass section) age 1+ WSCT densities have declined approximately $75 \%$ since the failure of the Mike Horse tailing dam. The percent trout species composition for Flescher Pass section for 1999 is located in Figure 7.

Reach 2: Lincoln to Arrastra Creek The upper portion of this alluvial reach gains most of its base flow from groundwater and spring creeks. Water quality and complexity improve substantially compared to reach 1 . Mainstem brown trout spawning is concentrated in the upper portion of this reach and in the spring creeks near Lincoln. Several tributaries enter the river, the majority of which have been identified with some level of fisheries impairment. Some tributaries are at various stages of restoration. Fish populations consist primarily of resident brown trout, fluvial WSCT in low but increasing densities and very low densities of fluvial bull trout. Telemetry studies indicate several tributaries in this reach and upstream of Lincoln (reach 1) provide native fish recruitment. Copper Creek (a tributary to the Landers Fork) is the primary spawning site for fluvial bull trout within this reach. Recent whirling disease monitoring reveals a gradual increase in infection level in this section of the Blackfoot River. When last surveyed in 1999, total trout densities (fish $>6.0^{\prime \prime}$ ) in the Canyon Section of reach 2 were 55 fish/1000'. The percent trout species composition for this survey is located in Figure 7.

Reach 3: Arrastra Creek to Nevada Creek This reach of river is low gradient, highly sinuous and subject to 1) active stream bank erosion, 2) deposition of fine sediment, and 3 ) winter anchor-ice formation beginning in the lower portion of this reach and extending down the remaining length of the Blackfoot River. Fine sediment limits instream production of food organism. A limited amount of mainstem brown trout spawning occurs in reach 3 although surveys indicate very low juvenile densities. There are no tributaries entering this reach of river, which further limits recruitment. Irrigation reduces instream flows resulting in late-summer and early-fall low flow conditions. Evaluation of irrigation ditch entrainment is ongoing. Initial ditch evaluations indicate juvenile entrainment in some ditches, further hindering recruitment. Although a main river population survey section does not exist in this reach, other fisheries investigations suggest low densities in the upper portion of this reach, decreasing to very low densities in the downstream portion of this reach.

Reach 4: Nevada Creek to the North Fork In this reach, channel gradient increases and the river becomes laterally confined by glacial moraine. This reach is subject to chronic water quality problems originating from Nevada Creek, which enters at the upper boundary of this reach. This reach exhibits elevated nutrients levels, low summer flows, high summer water temperatures, anchor-ice formation in the winter and high levels of fine sediment in substrates. All tributaries entering this reach are fisheries impaired due largely to irrigation and riparian degradation. Tributaries support WSCT in the headwaters but not in lower reaches. Poor recruitment limits river salmonid populations and fish densities are very low for all species. These combined influences result in the lowest population densities for the mainstem Blackfoot River downstream of Lincoln. Fish population survey completed in 2004 recorded total trout densities (fish $>6.0^{\prime \prime}$ ) in the 
Figure 7. Percent trout species composition for five reaches of the Blackfoot River

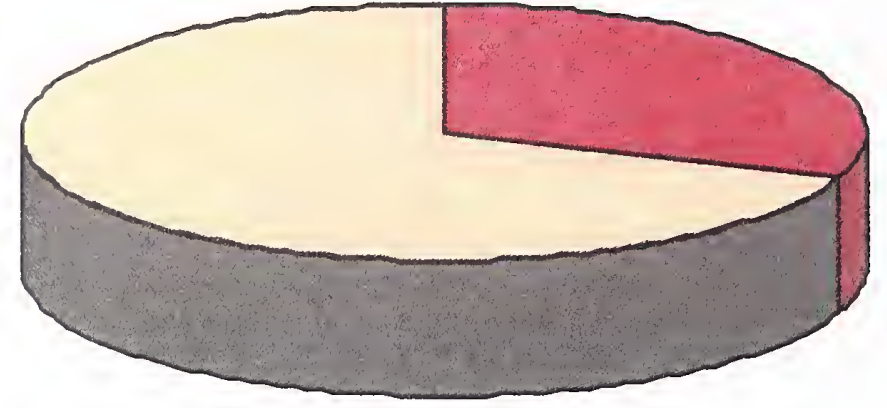

Reach 1: Flescher pass Section 1999

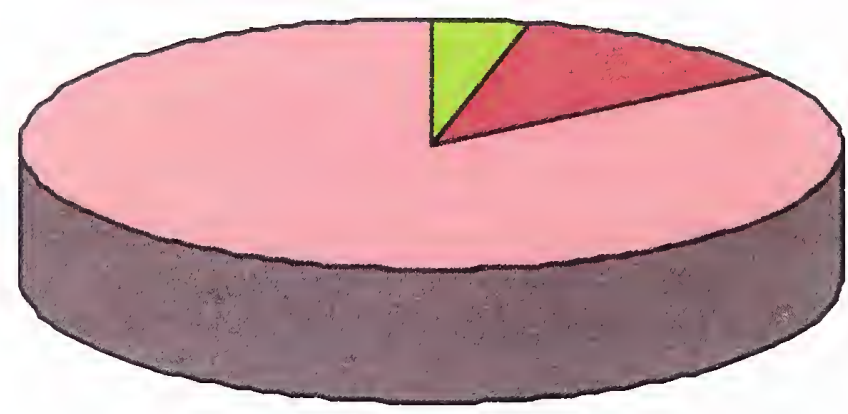

Reach 4: Wales Creek Section 2004

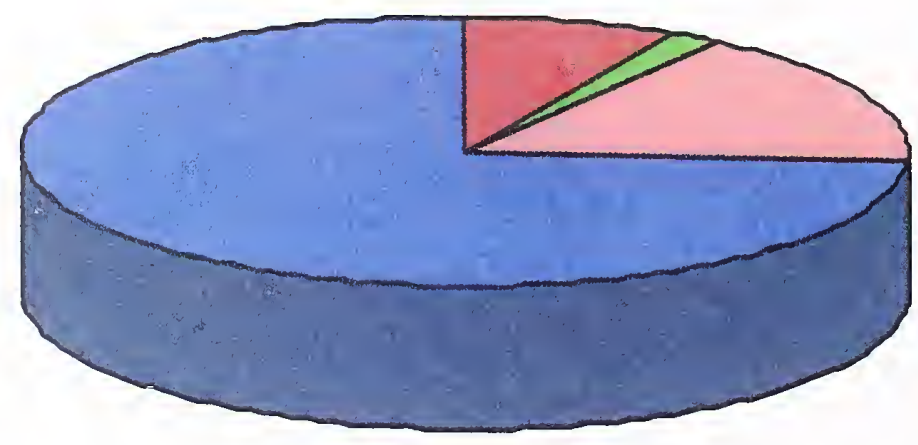

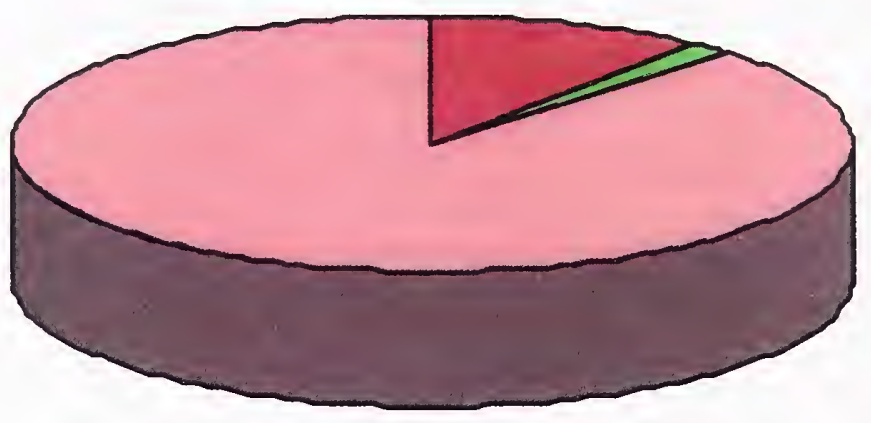

Reach 2: Canyon Section 1999

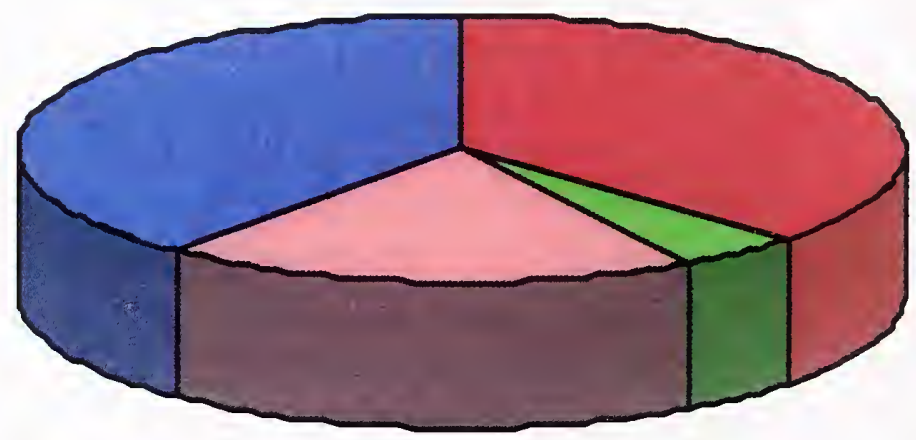

Reach 5: Scotty Brown Bridge Section 2004

\section{WSCT}

Bull Trout

Rainbow trout

Brown trout

Brook trout

Reach 6: Johnsrud Section 2004 
Wales Creek Section of reach 4 at 9 fish/1000'. The percent trout species composition for this survey is located in Figure 7.

Reach 5: North Fork to the Clearwater River The North Fork Blackfoot River approximately doubles the base flow of the Blackfoot River, bringing a much-needed influx of cold water to the main stem during summer. The influx of groundwater to the lower North Fork during base flow periods may also moderate severe winter conditions in a portion of the mainstem below the North Fork mouth. Below this junction, population densities of all salmonids increase due to the improved mainstem conditions and increased recruitment from more functional tributaries. Many tributaries of this reach are undergoing restoration activities. In this river section, bull trout densities increase due to recruitment from the two largest tributaries (Monture Creek and the North Fork) of this reach. Likewise, population densities of fluvial WSCT have increased. Brown and rainbow trout are common throughout this reach and the lower portions of most tributaries. Unfortunately, whirling disease has recently escalated to lethal levels in most rainbow trout tributary spawning and rearing sites entering this reach. This disease escalation coincides with the declining trend in rainbow trout densities in recent years. Fish population survey completed in 2004 recorded total trout densities (fish $>6.0$ ") in the Scotty Brown Bridge Section of reach 5 at 49 fish $/ 1000$ '. The percent trout species composition for this survey is located in Figure 7.

Reach 6: Clearwater River to the mouth Downstream of the Clearwater River mouth, the Blackfoot River becomes laterally contained over the remainder of its length by bouldery terraces and steep canyon walls. Milltown Dam, located at the mouth of the Blackfoot River has blocked the upstream movement of all species since 1907. Several tributaries enter this reach and those to the north originate primarily from industrial forestlands. Southern tributaries flow from the Garnet Mountains through primarily agricultural foothills before entering the mainstem. With few exceptions, the lower reaches of all southern tributaries are severely impaired, compared with streams to the north. Streams to the north of reach 6 appear to support the majority of Blackfoot River fish spawning. With increased recruitment of primarily rainbow trout, Blackfoot River fish populations increase substantially in the downriver direction. Unfortunately, like reach 5, rainbow trout densities are declining in reach 6 . Whirling disease is present near lethal levels in the mainstem but currently at sub-lethal levels in primary rainbow trout spawning streams. Brown trout and WSCT are stable to increasing in this river reach. Bull trout, originating primarily in the Monture and North Fork Watersheds have declined to very low densities. Fish population surveys completed in 2004 recorded total trout densities (fish >6.0") in the Johnsrud Section of reach 6 at 128 fish/1000'. The percent trout species composition for this survey is located in Figure 7.

\section{Tributary impairments}

Within the Blackfoot Watershed, the great majority of inventoried streams exhibit some level of physical and biological impairment (Table 1, Results Part II, Appendix Exhibit C). Tributaries exhibit fisheries impairments at a watershed scale, yet the level of impairment varies significantly within and among streams. The concentration and 
diversity of tributary fisheries problems also increases longitudinally, with the most serious problems found in lower stream reaches and primarily on private land. However, significant impairment occurs on State and Federal lands as well. Fisheries impairments result from a wide array of land use practices, such as mining pollution, excessive riparian timber harvest, excessive riparian grazing of livestock, poorly designed roads, non-point agricultural runoff, stream dewatering, channel alterations, fish losses to irrigation ditches and artificial barriers to fish movements, etc. These impairments have diminished fisheries and have led to the total loss of salmonids from entire stream reaches in some areas of the watershed.

Correcting fisheries impairments at a watershed scale will involve 1) protection of existing high quality tributary habitats, 2) restoring areas that are compromised, and 3 ) and a higher level of commitment to proper riparian management than currently exists in many areas of the Blackfoot Watershed. Bringing technical expertise, educational programs, landowner incentives and additional monitoring commitment at a broad scale is need to reverse the current level of fisheries impairments now present in the Blackfoot River Watershed.

Table 1. Anthropogenic fisheries impairment on 108 inventoried water bodies of the Blackfoot Watershed.

\begin{tabular}{lr} 
Type of impact & \# Streams \\
\cline { 2 - 2 } Concentrated livestock in riparian areas (feedlots, grazing) & 60 \\
Riparian vegetation & 52 \\
Instream flow & 46 \\
Road crossings and road drainage & 44 \\
Lack of complexity & 42 \\
Channel alterations & 41 \\
Irrigation (entrainment, dewatering, fish passage) & 40 \\
Whirling disease & 17 \\
Recreational (illegal harvest, high angler pressure, stream damage) & 15 \\
Mining & 15 \\
Residential & 5
\end{tabular}

\section{Whirling disease}

At this time, restoration planning in many stream reaches requires consideration of whirling disease - now firmly established at the low elevations of the watershed. Whirling disease, caused by the myxosporean parasite Myxobolus cerebralis, was first detected in the Blackfoot River in 1995 near Ovando. Since then, the disease has increased in distribution and intensity. It now infects the lower 122 miles of the mainstem Blackfoot River and continues to expand in the lower reaches of many tributaries (Figure 8). The current distribution of whirling disease overlaps with the distribution of rainbow trout and brown trout reproduction and occurs at levels harmful to rainbow trout populations in many streams.

Blackfoot River native WSCT and bull trout appear to have a diminished risk of contracting whirling disease, due in part, to habitat use and life history strategies that entail spawning and rearing in upper tributaries. Whirling disease severity typically 
increases in the downstream direction in Blackfoot River tributaries. This inverse relationship between elevation and infection may be a result of the parasite's lack of time in the area, low numbers of myxospores in the environment, or a lack of suitable habitat supporting T. tubifex.

Strategies to help moderate impacts of whirling disease are incorporated into this restoration plan. Strategies include: 1) improving migration corridors and rearing areas between headwater spawning streams and the Blackfoot River; 2) targeting restoration of native populations of WSCT and bull trout, whose life history could help reduce risk of infection by allowing the continual recruitment of these species to downstream river reaches; 3) habitat restoration - developing compatible streamside grazing practices, removing streamside feedlots and other methods of lowering sediment and nutrient input to streams: and 4) reducing other stress or mortality factors on trout populations such as ditch entrainment, low flows, poor habitat, etc.

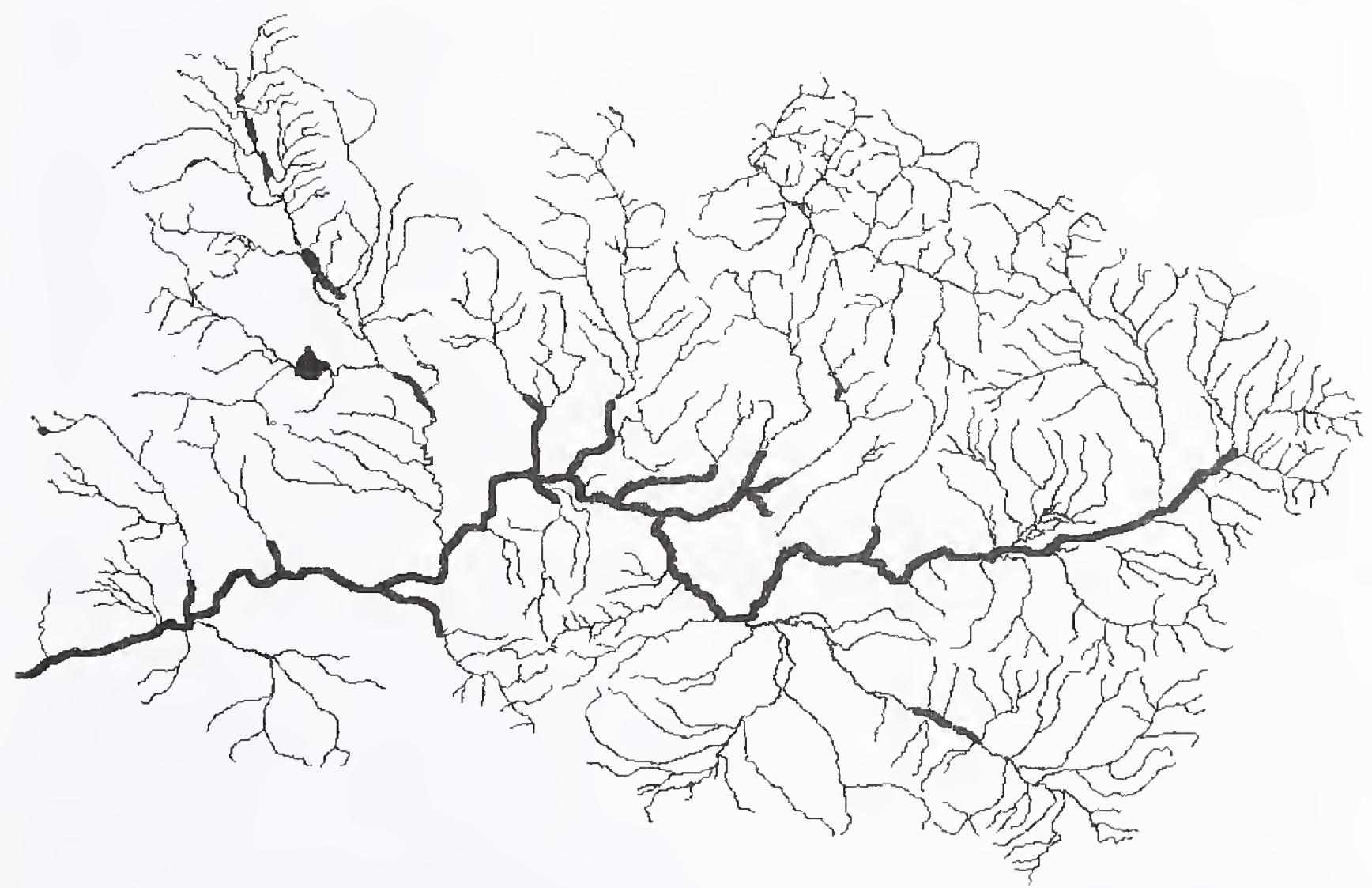

Figure 8. Generalized whirling disease distribution map for the Blackfoot Watershed. 


\section{PROCEDURES: RESTORATION PRIORITZATION}

\section{Prioritization Strategy}

At the request of the Blackfoot Challenge, FWP updated a restoration prioritization matrix established by Pierce et al. (2002). We incorporated 19 additional tributaries inventoried since 2001 and added six reaches of the Blackfoot River (1) mouth to Clearwater, 2) Clearwater to NF, 3) NF to Nevada Creek, 4) Nevada Creek to Arrastra, 5) Arrastra to Lincoln, 6) Lincoln to headwaters) bringing the total number of prioritized water bodies to 108 . We also incorporated the DEQ 303(d) list of water quality impaired streams and the FWP dewatered stream list to the prioritization matrix. This allowed TMDL and long-term water conservation strategies to be considered within a context of overall fisheries priorities. We then re-prioritized and ranked all water bodies using multiple criteria. We based stream scores on a hierarchical point system with emphasis on biological benefits (150 total possible points) along with social and financial considerations (50 total possible points).

FWP fisheries personnel (Ron Pierce, Don Peters, Ryen Anderson and Craig Podner) were given the job of assigning data input and corresponding point values to the matrix. Scoring of some criteria (primarily social and financial considerations) necessarily relied on past landowner interviews, direct knowledge of tributaries, along with professional expertise and committee judgment for inventoried non-project streams.

For the biological benefits section of the matrix, streams with documented bull trout use received scores of $10,20,30$ or 40 points, depending on whether the stream supported spawning (20 points), rearing (10 points) or is a designated bull trout "core area" stream (10 points). Compared with other criteria, streams supporting bull trout received more points due to their: 1) "threatened" status under ESA along with State and Federal priorities for the recovery of this species; 2) high potential for improvement in the Blackfoot watershed; and 3) downstream and sympatric benefits to other species resulting from bull trout recovery efforts.

For streams supporting WSCT, an additional zero to 20 points were possible, depending on whether a stream supported no WSCT (zero points), resident WSCT (10 points) or fluvial WSCT use (20 points). Fluvial WSCT streams received a higher score than streams supporting resident fish due to 1) the precarious status of the fluvial lifehistory, 2) high sport fish value to the Blackfoot River, and 3) downstream and sympatric benefits to other species resulting from WSCT recovery efforts. Streams with fluvial WSCT status (20 points) were those identified through 1) telemetry studies, 2) direct observations of fluvial-sized fish by FWP fisheries personnel, or 3) direct tributaries to the Blackfoot River and biologically connected during high flows periods.

Streams received an additional zero, 10 or 20 points based on sport fishery value to the Blackfoot River. Streams with no sport fishery value (disjunct from the Blackfoot River) received zero points, single species sport fishery value (non-disjunct usually with WSCT) received 10 points, while non-disjunct streams that provide recruitment of multiple species (bull trout, WSCT, rainbow and brown trout) to the Blackfoot River received 20 points. We assumed connected streams supporting rainbow trout, brown trout and bull trout provided sport fishery value to the Blackfoot River. We assumed small non-direct and non-fluvial headwater tributaries to support primarily resident WSCT, and as such, these were not considered as providing sport fishery value to the 
Blackfoot River. We did not consider brook trout in this ranking due to their limited use of the Blackfoot River and adverse biological impacts to native species.

Stream restoration technical feasibility was also considered with zero points for not feasible and 20 points for streams considered technically feasible to restore. Streams with acid mine drainage or heavy metals (upper Blackfoot River and tributaries-not considered in this report), large instream reservoirs (upper Nevada Creek, Frazier Creek, and Wales Creek), over-appropriated water rights (lower Nevada Creek), major highway problems (Chimney Creek), and fully restored (Grantier Spring Creek) were considered not technically feasible to restore for the purposes of this report.

In addition to fisheries and feasibility criteria, streams with potential to increase instream flows (e.g. irrigation salvage potential) in the Blackfoot River were allotted 20 points. Finally, under the biological ranking section, streams with potential to improve downstream water quality by reducing 1) instream sediment (10 points), 2) water temperature (10 points), and 3) nutrient loading (10 points) could earn up to an additional 30 points. This water quality point system is based on FWP assessments independent of 303(d) impaired stream list.

For social and financial considerations, we used three criteria: 1) landowner and land manager cooperation $(5,10,15$ or 20 points) - a measure of perceived landowner cooperation; 2) costeffectiveness (5, 10 or 20 points) - an estimate of project cost $/ \mathrm{mile} ; \quad$ and demonstration/educational value of potential projects (5 or 10 points) - a measure of project uniqueness, landowner interest and project access.

We transferred matrix values to an EXCEL spreadsheet
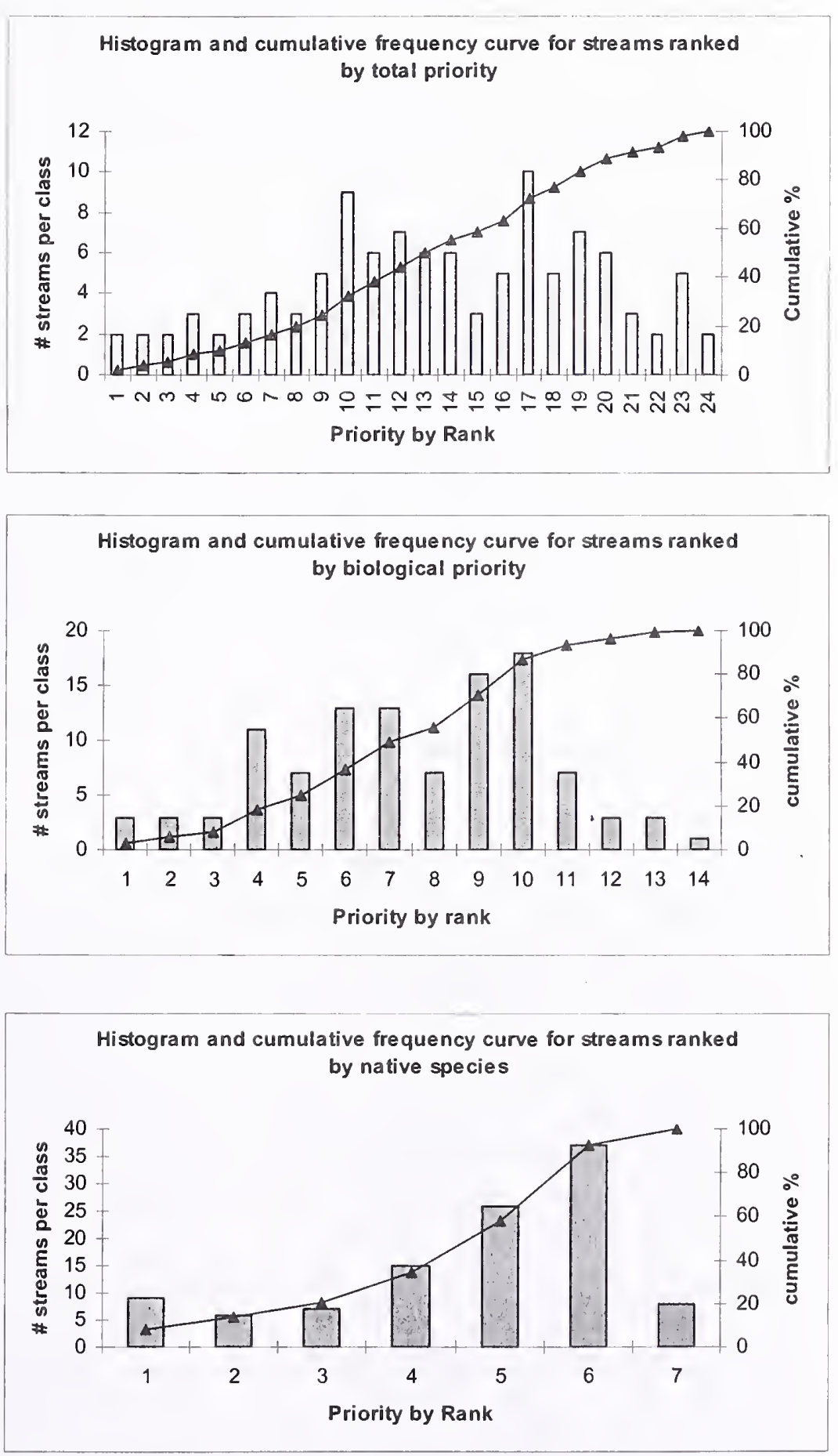

Figure 9. Histograms and cumulative percentage curves used to develop prioritization categories. 
(Appendix Exhibit B), where we sorted all 108-stream bodies by total score and then prioritized streams by total rank. High scores are high priorities and are represented as low ranking values. For instance Monture Creek received the highest total score (175 points) for all streams and thus ranked $1^{\text {st }}$ in total priority. We used this scoring and ranking method for all categories that rely on several numerical fields.

We scored and ranked all 108 streams by: 1) total rank, 2) biological rank, 3) native species rank (bull trout and WSCT fields), 4) sport fishery value, 5) potential to increase instream flow to the Blackfoot River, 6) potential for downstream water quality improvements, and 7) social and financial considerations. We then sorted the matrix by the primary priority criteria (total rank, biological rank, and native species rank) and plotted histograms with their associated cumulative percentage curves. For clusters of class values that approximated the 0-33, 34-66, and 67-100 percentiles, we assigned a respective high, moderate and low priority value (Figure 9). We also added the FWP dewatered stream list and DEQ 303(d) list to the matrix and sorted streams with these attributes by total restoration priority (dewatered stream listAppendix Exhibit D; 303(d) list - Table 2).

\section{Prioritization shortcomings}

It is important to note that our ranking criteria does not consider many complex restoration-related issues, such as: 1) fisheries potential of sites, 2) potential contribution to connected systems, 3) severity of impacts to other systems, .4) population size, 5) native and non-native species interactions, 6) WSCT genetic concerns, 6) numerical water quality standards and criteria, or 7) industrial-scale timber harvesting practices, public land or hard-rock mine drainage issues, or 8) other specific agency programs geared toward fisheries and water quality improvements. Some of these

Figure 10. Dewatered streams of the Blackfoot Watershed: human induced (top) and natural dewatering (hottom) 
issues are covered in the native species issues section and individual stream results section. Others issues should be considered on a project specific basis during early restoration development phases.

Our prioritization scheme attempts to guide the limited resources of the Blackfoot Cooperators to biologically important tributaries located primarily on private lands. Although the prioritization is intended to guide restoration activities, as new information becomes available and as additional limiting factors are identified low priorities may be elevated potentially triggering restoration action. We recognize unique restoration opportunities may be presented, and that continued input from landowners and managers will help guide the Blackfoot River restoration initiative.

Table 2. Thirty-eight streams on the 303(d) (post-1996) list sorted by total priority rank.

\begin{tabular}{lcllll}
\multicolumn{1}{c}{ Stream Name } & Total Rank & \multicolumn{1}{c}{ Stream Name } & Total Rank & \multicolumn{1}{c}{ Stream Name } & Total Rank \\
\hline Monture Creek & 1 & Nevada Spring Cr. & 11 & Ashby Creek & 17 \\
Poorman Creek & 2 & Yourname Creek & 11 & Camas Creek & 17 \\
Belmont Creek & 4 & Pearson Creek & 12 & Murray Creek & 17 \\
Rock Creek & 4 & Wales Creek & 12 & Washoe Creek & 18 \\
Kleinschmidt Cr. & 5 & Arrastra Creek & 13 & Buffalo Gulch & 19 \\
Blanchard Creek & 7 & Blackfoot River 5 & 13 & Cottonwood Cr. (Nev.) & 19 \\
Warren Creek & 7 & Cleanwater River & 13 & Jefferson Creek & 19 \\
Elk Creek & 8 & Douglas Creek & 13 & Nevada Cr. (lower) & 19 \\
Blackfoot River 1 & 9 & Nevada Cr.(upper) & 14 & Washington Creek & 19 \\
Blackfoot River 2 & 9 & Union Creek & 14 & Frazier Creek & 20 \\
Blackfoot River 4 & 9 & Willow Cr. (upper) & 14 & Gallagher Creek & 20 \\
McElwain Creek & 10 & Black Bear Creek & 16 & Ward Creek &
\end{tabular}

\section{Drought Prioritization}

Stream dewatering, whether natural or human induced, can result in significant fisheries declines. In many cases, these declines can be mitigated by 1) managing for native species whose life histories have evolved with cycles of drought; 2) managing water use (instream flows) in specific water bodies based on specific population needs, and by 3 ) restoring habitat quality by correcting human-induced limiting factors that either exacerbate drought or introduce additional stressors upon fish communities.

In order to develop long-term water conservation strategies under the Blackfoot Emergency Drought Response Plan, we added dewatered streams to the prioritization matrix (Figure 10). Dewatering refers to a reduction in the stream-flow (natural and human-related) below the point that habitat is deemed adequate for fish. There are also two categories of dewatering: 1) chronic dewatering - streams where dewatering is a significant problem in virtually all years; and 2) periodic dewatering - streams where dewatering is a significant problem only in drought or water-short years. For this report, both categories were combined into a single list. This FWP generated list is based on direct field observations, measured flows, instream flow models, fisheries assessments 
and biological opinion. Integrating the dewatered stream list allows us to identify and prioritize instream flow enhancement projects consistent with biological priorities.

The dewatered stream list (Appendix Exhibit D) contains 54 water bodies (excluding the Clearwater River upstream of Blanchard Creek) and an estimated 194 miles of affected stream. Of this total, natural dewatering on 17 streams and totals 49 river miles, which includes 11 miles of the upper Blackfoot River. Human-related dewatering occurs on an estimated 45 tributaries and influences an estimated total of 165 miles of stream, including $~ 34$ miles of the middle Blackfoot River. A combination of both natural and human-related dewatering occurs on 8 streams.

\section{RESULTS PART I: SUMMARY}

In the Results Part I Section, we organizing all priority streams based on the total priority (high, moderate and low) classes. For each of these three classes, the names and locations of water bodies are referenced in maps and numerically referenced to tables (Figures 11, 12 and 13). Each class has a brief discussion of restoration, recovery and conservation themes common to that level of priority.

Results Part II then includes the individual descriptions of all 108 water bodies. Each description includes fish species present and general impairments (including dewatering and TMDL status), prioritization summaries, specific native species concerns, as well as an outline of restoration and monitoring activities. These tributaries are organized first by total priority class (high, moderate, low), then by total restoration rank and then alphabetically. Appendix Exhibit $\mathrm{D}$ contains the summary tables showing priorities by total restoration, biological, native species priorities, as well as the dewatered stream list. The dewatered stream list is sorted by biological priority.

\section{High priority streams}

Of the 108 stream bodies, thirty-four received a high total priority rank (Figure 11). Projects in these watersheds will be high priorities for fisheries funding and project development under this restoration strategy. Streams bodies in this category include 1) three reaches of the mainstem Blackfoot River, 2) all major bull trout spawning streams, and 3) other direct tributaries to the Blackfoot River including several from the Garnet Mountains. These streams are biologically connected to the Blackfoot River, and generally support the strongest native fish populations.

Tributaries originating in the northern mountains within the watershed are generally the larger streams. Headwaters range from USFS lands with wilderness designation to intensively managed private industrial forestlands. To varying degrees, these streams represent some of the best opportunities to protect, restore and manage essential habitats occupied by communities of fluvial WSCT and bull trout. In lower stream reaches, several also support important recreational rainbow and brown trout fisheries, as well as brook trout. From a planning perspective, projects for these streams should be consistent with bull trout recovery plans and fluvial WSCT conservation plans unless site-specific measures suggest other actions.

The Garnet mountain stream ranked high due to in part water quality, flow enhancement potential and social considerations. These streams all possess human- 
induced limiting factors related to habitat problems. Streams in this category generally contain fluvial WSCT and other species important to the Blackfoot River sport fishery.

Listed 303(d) streams in the high priority category are 1) Monture Creek, 2) Poorman Creek, 3) Belmont Creek, 4) Rock creek, 5) Kleinschmidt Creek, 6) Blanchard Creek, 7) Warren Creek, 8) Elk Creek 9) Blackfoot River reaches 1, 2 and 4, 10) Chamberlain Creek, and 11) McElwain

\section{Moderate priority streams}

Thirty-four stream reaches fall in to the "moderate priority" category (Figure 5.02). Streams in this category would receive a moderate level of consideration for funding of fisheries-related restoration. Streams include three reaches of the upper Blackfoot River, many low-elevation tributaries to the Blackfoot River including several spring creeks, as well as a few outliners, including disjunct streams located higher in the

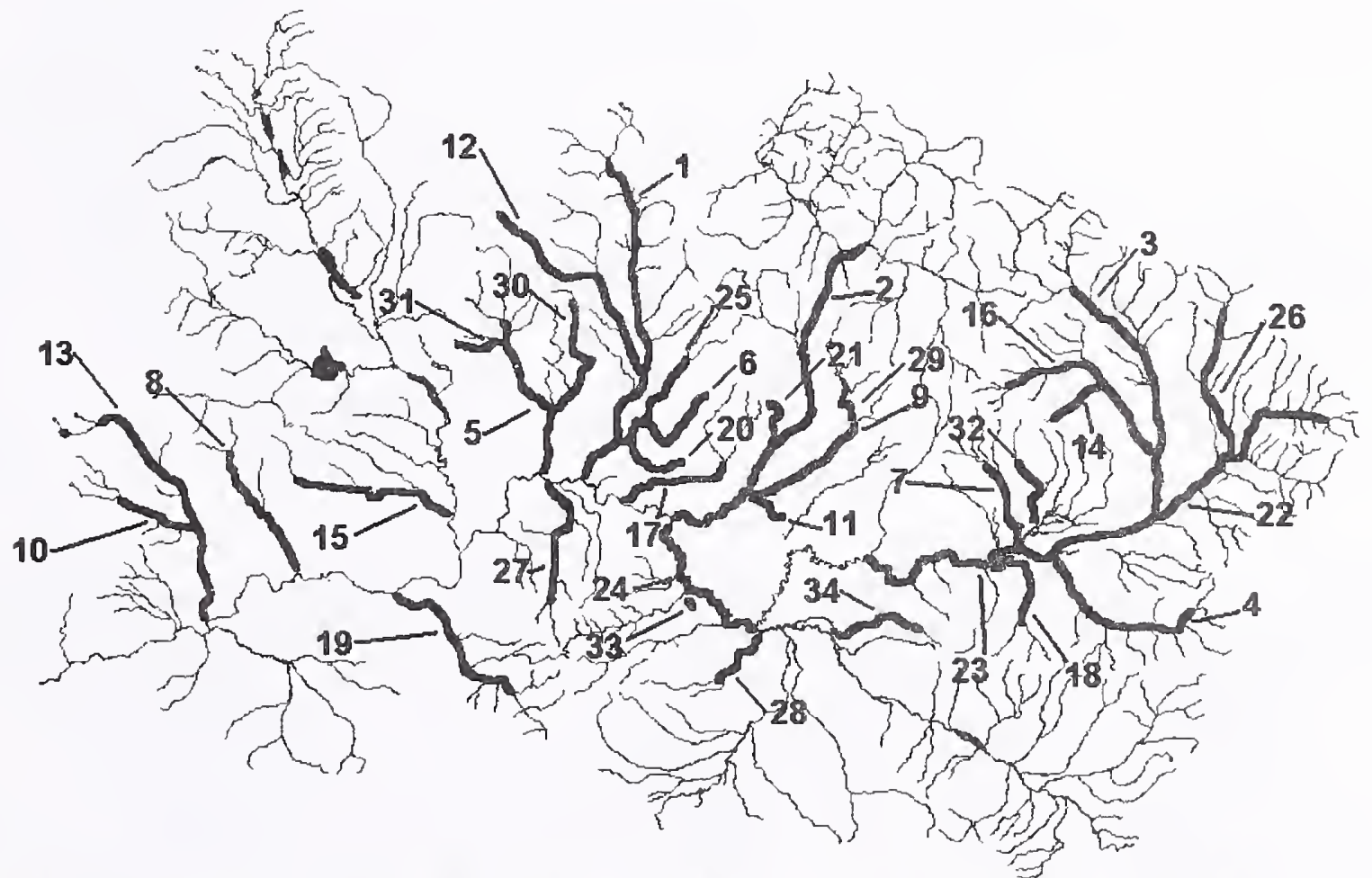

\begin{tabular}{|c|c|c|c|c|c|c|c|c|}
\hline Stream ID \# & Stream Name & $\begin{array}{l}\text { Total } \\
\text { Rank } \\
\end{array}$ & $\begin{array}{c}\text { Stream } \\
\text { ID } \# \\
\end{array}$ & Stream Name & $\begin{array}{l}\text { Total } \\
\text { Rank } \\
\end{array}$ & $\begin{array}{c}\text { Strean } \\
\text { ID }\end{array}$ & Stream Name & $\begin{array}{l}\text { Total } \\
\text { Rank } \\
\end{array}$ \\
\hline 1 & Monture Creek & 1 & 12 & Dunham Creek & 6 & 23 & Blackfoot River 2 & 9 \\
\hline 2 & N.F. Blackfoot R. & 1 & 13 & Gold Creek & 6 & 24 & Blackfoot River 4 & 9 \\
\hline 3 & Landers Fork & 2 & 14 & Snowbank Creek & 6 & 25 & McCabe Creek & 9 \\
\hline 4 & Poorman Creek & 2 & 15 & Blanchard Creek & 7 & 26 & Alice Creek & 10 \\
\hline 5 & Cottonwood Cr. (R.M.43) & 3 & 16 & Copper Creek & 7 & 27 & Chamberlain Creek & 10 \\
\hline 6 & Dick Creek & 3 & 17 & Warren Creek & 7 & 28 & McElwain Creek & 10 \\
\hline 7 & Beaver Creek & 4 & 18 & Willow Cr. (lower) & 7 & 29 & Salmon Creek & 10 \\
\hline 8 & Belmont Creek & 4 & 19 & Elk Creek & 8 & 30 & Shanley Creek & 10 \\
\hline 9 & Rock Creek & 4 & 20 & Hoyt Creek & 8 & 31 & Spring Cr.(Cottonwood) & 10 \\
\hline 10 & Gold Creek, W,F & 5 & 21 & Spring Creek (N.F.) & 8 & 32 & Stonewall Creek & 10 \\
\hline 11 & Kleinschmidt $\mathrm{Cr}$. & 5 & 22 & Blackfoot River 1 & 9 & 33 & Wales Spring Creek & 10 \\
\hline & & & & & & 34 & Wasson Creek & 10 \\
\hline
\end{tabular}

Figure 11. High priority stream of the Blackfoot River Watershed. 
watershed.

Most of the reaches that we consider moderate priorities are small direct tributaries to the Blackfoot River. Most of these are biologically and hydrologically (surface water) connected to the main stem Blackfoot River continually or during high flow periods. These tributaries support fluvial and stream resident WSCT and most support WSCT spawning and rearing. Restoration of these tributaries should be

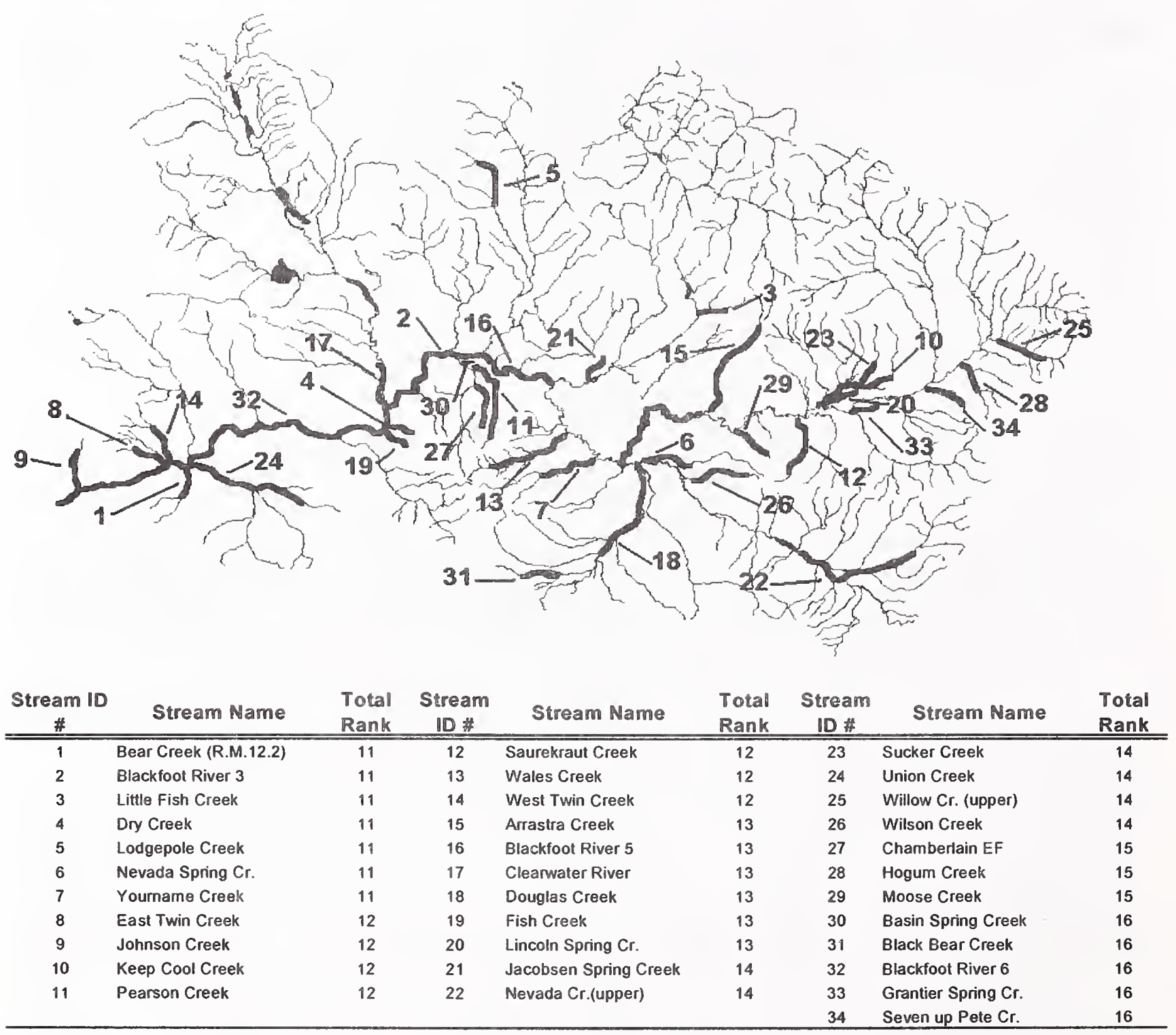

Figure 12. Moderate priority streams of the Blackfoot River Watershed.

generally viewed from a WSCT metapopulation conservation perspective. The lower portions of these tributaries variably contain rainbow trout, brown trout and brook trout. Streams generally support genetically unaltered WSCT in the upper watershed and introgressed WSCT in tributaries of the lower Blackfoot Watershed. With one exception (Arrastra Creek), these tributaries lack bull trout reproduction although many support limited bull trout rearing.

Other moderate priority streams are found both north and south of the general distribution pattern. The northern streams include lower priority bull trout core area 
streams. Stream on the south include several with potential for water quality and flow improvement or are ranked high with respect to social considerations.

Most streams in this moderate priority category support human-induced limiting factors and many controllable sources of fish mortality, such as entrainment of fish in irrigation ditches and stream dewatering. Most habitat-related problems can be reasonably corrected with sufficient commitment from landowners and resource managers. We have already begun to implement restoration project on many of these streams.

Streams on the 303(d) list considered moderate priority include: 1) Blackfoot River reaches 3, 5 and 6, 2) Nevada Spring Creek, 3) Yourname Creek, 4) Pearson Creek 5) Wales Creek, 6) Arrastra Creek, 7) Clearwater River, 8) Douglas Creek, 9) upper Nevada Creek, 10) Union Creek, 11) upper Willow Creek, and 12) Black Bear Creek.

\section{Low Priority streams}

Forty streams ranked in the "low priority" category (Figure 13). Low-priority

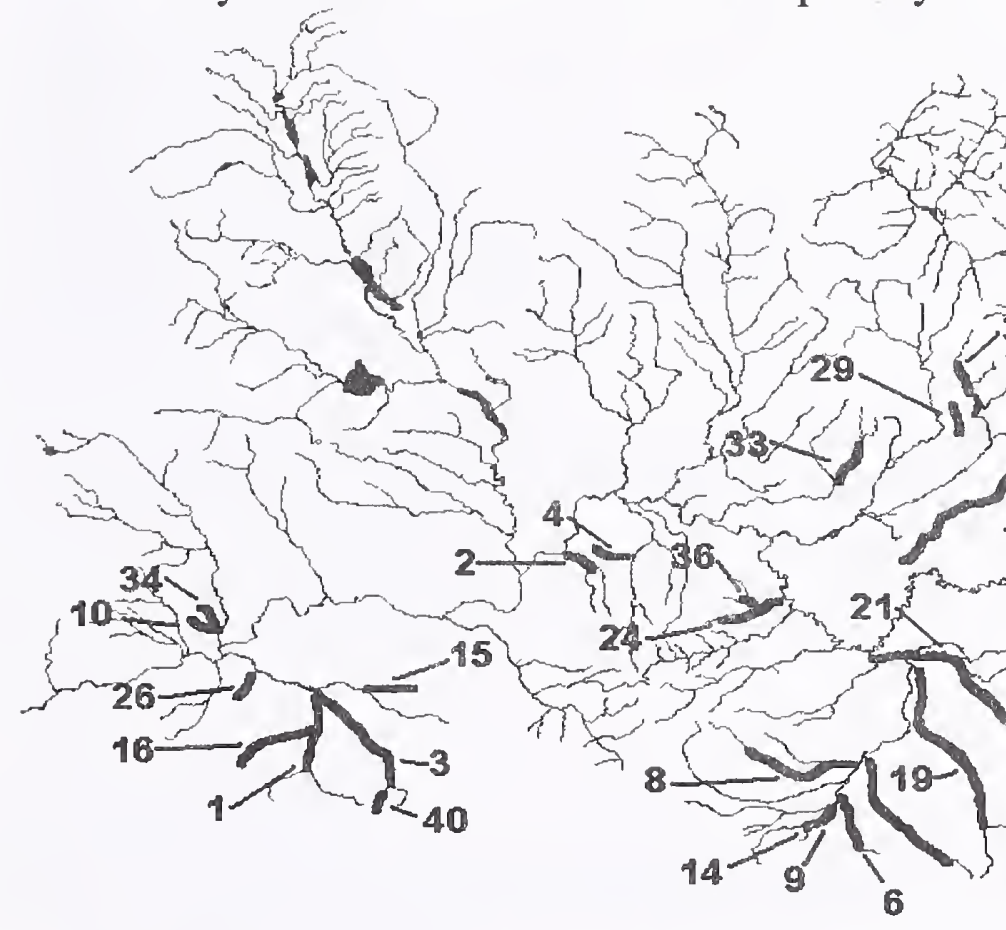

\begin{tabular}{|c|c|c|c|c|c|c|c|c|}
\hline Stream ID & Stream Name & $\begin{array}{l}\text { Total } \\
\text { Rank }\end{array}$ & $\begin{array}{c}\text { Stream } \\
\text { ID \# }\end{array}$ & Stream Name & $\begin{array}{l}\text { Total } \\
\text { Rank }\end{array}$ & $\begin{array}{c}\text { Stream } \\
10 \#\end{array}$ & Stream Name & $\begin{array}{l}\text { Total } \\
\text { Rank }\end{array}$ \\
\hline 1 & Ashby Creek & 17 & 14 & Sturgeon Creek & 18 & 27 & Humbug Creek & 20 \\
\hline 2 & Bear Creek (R.M.37.5) & 17 & 15 & Washoe Creek & 18 & 28 & Shingle Mill Creek & 20 \\
\hline 3 & Camas Creek & 17 & 16 & Arkansas Creek & 19 & 29 & Bear Creek trib. to N.F. & 21 \\
\hline 4 & Chamberlain WF & 17 & 17 & Buffalo Gulch & 19 & 30 & Strickland Creek & 21 \\
\hline 5 & Chicken Creek & 17 & 18 & California Gulch & 19 & 31 & Ward Creek & 21 \\
\hline 6 & ChImney Cr. (Douglas) & 17 & 19 & Coltonwood Cr. (Nev.) & 19 & 32 & Indian Creek & 22 \\
\hline 7 & Little Moose Creek & 17 & 20 & Jefferson Creek & 19 & 33 & Warren Creek,Doney Lak€ & 22 \\
\hline 8 & Murray Creek & 17 & 21 & Nevada Cr. (lower) & 19 & 34 & Burnt Bridge Creek & 23 \\
\hline 9 & Sheep Creek & 17 & 22 & Washington Creek & 19 & 35 & Clear Creek & 23 \\
\hline 10 & Warm Springs Cr. & 17 & 23 & Bartlett Creek & 20 & 36 & Frazier Creek, NF & 23 \\
\hline 11 & Finn Creek & 18 & 24 & Frazier Creek & 20 & 37 & Gleason Creek & 23 \\
\hline 12 & Halfway Creek & 18 & 25 & Gallagher Creek & 20 & 38 & McDermott Creek & 23 \\
\hline \multirow[t]{2}{*}{13} & Mitchell Creek & 18 & 26 & Game Creek & 20 & 39 & Chimney Cr. (Nevada) & 24 \\
\hline & & & & & & 40 & Smith Croek & 24 \\
\hline
\end{tabular}

Figure 13. Low priority streams of the Blackfoot River Watershed.

streams will not receive the same level of fisheries restoration consideration as high or 
moderate priority streams without a concerted local effort. However, despite a low ranking, most low priority streams possess locally valuable fisheries or potential for recovery. The majority (28) of low priority streams fall into two large sub-basins (Union Creek and Nevada Creek) of the Blackfoot watershed. In these areas, reservoirs, subdivision and agriculture have either greatly reduced, or eliminated the biological connection with the mainstem. These streams no longer support fluvial native fish or contribute significantly to sport fisheries of the Blackfoot River. Rather, these are generally small headwater streams supporting stream resident WSCT or are degraded reaches that no longer support salmonids.

Several low priority streams possess site-specific stream resident WSCT concerns that will be considered before restoration activities involving fish passage are implemented. Where WSCT populations are physically isolated, restoration measures should preserve the genetic integrity of "pure" populations, fully consider downstream influences, and avoid exposure to hybridizing and invasive species. Where fisheries restoration is pursued, it should generally be conducted from the headwaters in a downstream direction. These methods would focus on expanding the size of individual populations by improving habitat conditions in headwater areas. This approach should improve populations, while providing sufficient time to evaluate: 1) the influence of climate change, 2) expansion potential of unwanted species, 3) disease risks, and 4) the efficacy of differing restoration methods implemented on similar streams. In all cases involving resident WSCT streams, FWP fisheries biologists should be involved in restoration planning from the onset.

Streams on the 303(d) list considered low priority include: 1) Ashby Creek, 2) Camas Creek, 3) Murray Creek, 4) Washoe Creek, 5) Buffalo Creek, 6) Cottonwood Creek (trib. of Nevada Creek), 7) Jefferson Creek, 8) lower Nevada Creek, 9) Washington Creek, 10) Frazier Creek, 11) Gallagher Creek, and 12) Ward Creek. 


\section{RESULTS PART II: TRIBUTARY DESCRIIPTIONS HIGH PRIORITY STREAMS}

\section{MONTURE CREEK: Priority - High \\ Description}

Monture Creek, a large 4th order tributary to the middle Blackfoot River, originates in a roadless watershed along southern flanks of the Bob Marshall Wilderness. Monture Creek is $\sim 24$ miles long, with the lower $\sim 12$ miles flowing through private ranch land. Monture Creek, located in the bull trout core area, ranked as a high priority for all criteria. This ranking is due to 1) bull trout spawning, rearing and core area status, 2) presence of fluvial WSCT, 3) a high (multi- species) sport fishery value, 4) high potential to improve water quality in the Blackfoot River, and 5) cooperative lands resulting in a high ranking for the social category. Monture Creek, a primary spawning and rearing stream to the middle Blackfoot River, supports populations of fluvial bull, fluvial WSCT, rainbow trout and brown trout and resident brook trout. Most fisheries impairments for Monture Creek were corrected over the last decade. However, localized impairments in the lower Monture Creek include: 1) localized channel alterations, 2) lack of instream complexity, 3) degraded riparian areas due to excessive livestock access to the stream. Monture Creek first tested positive for whirling disease in 2000 and infections in 2002 were detected at a mean grade of 3.22.

\section{TMDL Issues}

Listing history: 1996-Yes; 2000-Yes; 2002-Yes; 2004-Yes.

Listed causes of impairment: Habitat alterations, siltation.

\section{Dewatering Issues}

Middle Monture Creek between mile 12 and 15 are on the dewatered stream list due to natural losses.

\section{Native Species Issues}

Fluvial bull trout spawning stream, proposed critical bull trout habitat, bull trout core area stream, bull trout recovery/recreational conflict area.

Fluvial WSCT spawning

WSCT genetic composition: tested $94 \%$ WSCT

\section{Restoration Activities}

\section{Past Restoration}

Restoration actions began in 1990 on two large ranches encompassing nine miles of stream. Work included riparian fences on critical bull trout spawning sites, developing low-impact grazing, creating off-stream water developments, removing two winter livestock feeding areas, planting woody vegetation and two miles of instream habitat restoration work. Two water conservation projects have been implemented.

\section{Current/Planned Restoration}

Monture Creek is a high priority restoration stream. Restoration activities will continue as opportunities are presented. 


\section{Monitoring Activities}

Past Monitoring

FWP inventoried fish population surveys in 1989 and resurveys sampling sites in 1994, 1998, 2000 and 2002. FWP measured stream temperatures in 1998, 1999 and from 20012004 and stream flows in 1989, 2000 and 2004. FWP has conducted annual bull trout redd counts beginning in 1989. Fitzgerald (1996) conducted a riparian health survey in 1995. Koopal (1998) conducted a large wood survey in 1998. FWP conducted geomorphic surveys, winter water temperature and $\mathrm{McNeil}$ Core samples near a bull trout spawning sites in 2004. FWP began whirling disease monitoring in 1998. FWP conducted whirling disease tests from 1997 through 2003. Telemetry studies beginning in 1995 identified Monture Creek as a critical fluvial bull trout WSCT spawning stream. An ambient water quality survey was completed in 1989 (Ingman et al. 1990).

\section{Ongoing Monitoring}

Monitoring of existing fish population survey sites, bull trout redds, water temperatures, and whirling disease are expected to continue.

\section{Planned Future Monitoring}

None although grazing pressure on stream banks prone to damage should be monitored.

\section{NORTH FORK BLACKFOOT RIVER: Priority - High Description}

The North Fork Blackfoot River, the largest tributary (4th order) to the Blackfoot River, drains the Scapegoat Wilderness before entering private land at river mile $\sim 17$. The North Fork received a high rank on the restoration priority and total rank list due to its 1) bull trout core area status (spawning and rearing), 2) presence of fluvial WSCT, 3) a high (multi- species) sport fishery value and 4) high potential to increase flows in the Blackfoot River. The North Fork also has some potential to improve water quality by reducing sediment and temperature. Along with supporting one of the Blackfoot watersheds largest bull trout spawning populations and fluvial WSCT, the North Fork also supports rainbow trout, brown trout and low densities of resident brook trout. These species inhabit the North Fork at a varying distribution at low to moderate densities. Fisheries impairments are confined to localized areas of middle reaches include: 1) localized channel alterations that lack instream complexity, 2) suppressed riparian vegetation, and 3) instream flow during in critical bull trout migration corridors due to natural dewatering and irrigation. Whirling disease is also present in the lower drainage.

\section{TMDL Issues}

Listing history: 1996-Yes; 2000-No; 2002-No.

Listed causes of impairment: Habitat alterations, siltation.

\section{Dewatering Issues}

The North Fork of the Blackfoot River is on the dewatered stream list between stream mile 6.2-12.0 due to natural losses and irrigation.

\section{Native Species Issues}

Proposed bull trout critical habitat, bull trout spawning stream, bull trout core area, bull trout recovery/recreational conflict area. 
Fluvial WSCT migration corridor

\section{Restoration Activities}

\section{Past Restoration}

Restoration on the North Fork has involved working with irrigators. Projects involve screening five irrigation canals to prevent fish losses, nine miles of stream under improved riparian grazing systems, and streambank stabilization at two locations to protect infrastructure related to diversions and fish screens. One diversion point has been moved and a ditch retired resulting in enhanced flows.

\section{Current/Planned Restoration}

Instream flow enhancement project are being considered with several irrigators.

\section{Monitoring Activities}

\section{Past Monitoring}

FWP inventoried fish population in 1989 and re-surveyed sample sites in 1994, 1998, 2000 and 2002. Bull trout redd counts began in 1989. The USGS has a flow monitoring station (\#12338300) near the mouth with six years of continuous data. The USFS periodically collects flow data near the FS boundary and the DNRC collected flow data at Ryan Bridge. FWP monitored water temperatures near mouth from 1998 through 2004. FWP began testing for whirling disease in 1996. The DNRC completed a hydrologic analysis of ground and surface water in 2001 (Roberts, 2001). FWP tested for whirling disease from 1997-2004. Telemetry identified this stream as a fluvial WSCT migration corridor, summering and wintering area. An ambient water quality survey was completed in 1989 (Ingman et al. 1990).

\section{Ongoing Monitoring}

Ongoing monitoring includes periodic fish population surveys at established sites, annual bull trout redd counts, continued water temperature and whirling disease monitoring. DNRC and BBCTU ground and surface water monitoring.

\section{Planned Future Monitoring}

None beyond ongoing monitoring.

\section{LANDERS FORK: Priority - High \\ Description}

The Landers Fork, a 4th order stream and major tributary to the upper Blackfoot River, originates in the Scapegoat Wilderness and flows $\sim 28$ miles. The upper $\sim 16$ miles are entirely public (National Forest) land with mixed ownership in lower stream reaches. At mile 7.2 Silver King Falls creates a natural barrier to upstream fish movements. The Landers Fork watershed support genetically unaltered WSCT throughout the watershed. Upstream of Silver King Falls, a population of Yellowstone cutthroat trout is also established in Big Horn Lake, which may put the WSCT genetic status of the upper drainage at risk. Below Silver King Falls, the Landers Fork supports fluvial bull trout, fluvial WSCT along with very low densities of brown trout and brook trout. The Landers Fork received the highest total rank due to its bull trout core area status, high native species value, high (multi-species) sport fishery value to the Blackfoot River, potential to increase flow in the Blackfoot and potential to improve water quality in the Blackfoot River. Fisheries impairments in the lower seven miles include: 1) localized channel 
alterations, 2) lack of instream complexity due in part to channel clearing activities and flood events, 3) riparian vegetation suppression, and 4) instream flow problems, which appear to partially result from over-widened channels. Over-widened channels contribute to elevated water temperatures upstream of Copper Creek.

\section{TMDL Issues}

Listed

\section{Dewatering Issues}

Natural dewatering occurs in approximately one mile of stream near the mouth of Copper Creek.

\section{Native species Issues}

Bull trout core area stream, proposed critical bull trout habitat, critical migration corridor Fluvial WSCT spawning stream

WSCT genetic composition: tested 100\% WSCT above and below Silver King Falls

\section{Restoration Activities}

\section{Past Restoration}

None

Current/Plamned Restoration

None

\section{Monitoring Activities}

\section{Past Monitoring}

FWP inventoried fish populations in 1989 and re-surveyed sample sites in 1999, measured stream temperatures in 1998, 1999, 2001, 2002 and 2004 and stream flows in 1989 and 2000. In October 2000, FWP conducted a habitat survey with an emphasis on pool size and frequency, LWD abundance and function and geomorphic data including bankfull measurements and pebble counts. FWP conducted whirling disease tests in 1997. Telemetry identified this stream as a fluvial WSCT spawning stream. An ambient water quality survey was completed in 1989 (Ingman et al. 1990).

\section{Ongoing Monitoring}

Periodic fish population and water temperature measurement are ongoing

\section{Planned Future Monitoring}

None beyond periodic monitoring.

\section{POORMAN CREEK: Priority - High}

\section{Description}

Poorman Creek, a $3^{\text {rd }}$ order tributary to the upper Blackfoot River, flows $\sim 14$ miles through public land (National Forest) in upper reaches and private ranch land in mid to lower reaches. Poorman Creek ranks high on the restoration priority and total rank list due to high native species and biological values. High biological ranks are the result from bull trout spawning and rearing, presence of fluvial WSCT and a multi-species sport fishery value. Poorman Creek also has potential to increase flows, and ranks high in potential to improve water quality in the Blackfoot River. Poorman Creek supports 
populations of bull trout, fluvial WSCT, brown trout and resident brook trout. Low numbers of bull trout use the upper reaches including the South Fork for spawning and rearing. WSCT and brook trout are found in low densities in the middle to upper reaches of Poorman Creek, while brown trout are found in low numbers in the lower and middle reaches. Fisheries impairments located primarily in the lower reaches include: 1) channel alterations related to placer mining, 2) road crossings, fords and sediment delivery, 3) irrigation impacts (fish entrainment and fish passage), 4) excessive livestock grazing impacts to riparian vegetation resulting and stream bank degradation, and 5) dewatering resulting from natural losses and irrigation.

\section{TMDL Issues}

Not listed

\section{Dewatering Issues}

The lower two miles of Poorman Creek is on the dewatered stream list due to natural losses and irrigation. In 2002, a project to enhance flows during the high flows was undertaken in order to improve native fish migrations. The project involved a flood-tosprinkler irrigation conversion. The project includes enhanced flows at the upper portion of the intermittent reach.

\section{Native Species Issues}

Bull trout spawning stream

WSCT genetic composition: tested $100 \%$ WSCT

\section{Restoration Activities}

\section{Past Restoration}

Restoration projects near the mouth focus on high flow instream flow enhancement project and are still in the implementation phases. This project involved a flood to sprinkler conversion designed to 1) improve migrations of WSCT, 2) enhance summer flows in the naturally dewatered section and 3) prevents fish losses of fish to irrigation ditches. The project also involved the construction of three bridges and the removal of two culverts. Fencing, off-stream water developments are other components to the project are under construction. Upstream projects involve culvert replacements with structures suitable to pass fish. The USFS plans restoration work in the upper tributaries of the drainage.

\section{Current/Planned Restoration}

Shrub plantings and livestock measurement measures are planned near the mouth. Addition road crossings are planned in upper Poorman Creek.

\section{Monitoring Activities}

\section{Past Monitoring}

FWP conducted fish population surveys in 1989, 1991, 1999, 2001, 2003 and 2004 and measured stream temperatures in 1999-2003 and stream flows in 1989, 2000, 2001 and 2003. FWP tested for whirling disease in 2004.

\section{Ongoing Monitoring}

Ongoing monitoring includes fish population and instream flow monitoring in the lower 
portion of Poorman Creek.

Planned Future Monitoring

None beyond ongoing monitoring.

\section{COTTONWOOD CREEK (rm 43): Priority - High}

\section{Description}

Cottonwood Creek, a major, a 3rd order tributary to the middle Blackfoot River, flows $\sim 16$ miles through National Forest in upper reaches and mixed State and private lands in the lower $\sim 12$ miles. Cottonwood Creek ranks high on the restoration priority list for total and biological rank, including high native species and sport fishery values. These high rankings result primarily for the status as a bull trout core area and fluvial WSCT stream, and multi-species assemblage (rainbow and brown trout) in lower stream reaches. It has low potential water quality benefits with some potential for sediment reduction. Cottonwood Creek also has potential to increase downstream flows to the Blackfoot River. Low densities of rainbow and brown trout inhabit the lower reaches while moderate numbers of brown and brook trout dominate the middle reaches. Moderate densities of WSCT and with low numbers of bull trout dominate the upper reaches. Principle fisheries impairments, located in the middle and lower reaches, include: 1) lack of complex fish habitat (instream wood); 2) livestock induced stream bank degradation, 3) riparian vegetation suppression, and 4) whirling disease. Whirling disease was first detected in Cottonwood Creek in 1998. In 2002, whirling disease levels were detected at a mean grade of 4.5 .

\section{TMDL Issues}

Listing history: 1996-Yes; 2000-No; 2002-No; 2004-No, fully supporting.

Listed causes of impairment: Flow and habitat alterations, siltation.

\section{Dewatering Issues}

The middle reach of Cottonwood Creek (mile $4.4-10.0$ ) is on the dewatered stream lists due to natural losses and irrigation.

\section{Native Species Issues}

Bull trout core area, proposed critical habitat

WSCT genetic composition: tested $100 \%$ WSCT

\section{Restoration Activities}

\section{Past Restoration}

Some restoration work has been completed in lower Cottonwood Creek. The work involves riparian grazing improvements and fish friendly irrigation upgrades (fish screens and fish ladders) at two locations. A water lease was implemented in 1997 to improve fish passage in native fish migration corridors. In 2003, an open ditch in lower Cottonwood Creek was shut down with the conversion of a flood to sprinkler irrigation.

\section{Current/Planned Restoration}

None

\section{Monitoring Activities}




\section{Past Monitoring}

FWP inventoried fish populations in 1989, 1991-92 and conducted annual fish population survey in the headwaters at a water-lease monitoring site between 1997 and 2004. FWP monitored stream temperatures in 1997, 1999 and 2001-2004 and stream flows in 1989, 2000 and 2003. Bull trout redd surveys have been attempted but low number of spawners has limited biologists ability to identify primary spawning sites. Whirling disease was first detected in Cottonwood Creek in 1995. A graduate student completed whirling disease research related $t$. tubifex, channel features and whirling disease. Whirling disease sampling continued in 1997-1999 and 2002. An ambient water quality survey was completed in 1989 (Ingman et al. 1990).

\section{Ongoing Monitoring}

FWP ongoing monitoring involves annual fish population surveys and diversion withdrawal in the area influenced by water leases. Whirling disease monitoring is periodic and water temperatures are monitoring on an annual basis.

\section{Planned Future Monitoring}

In the next few years, FWP plans to resurvey several fish population monitoring sites established in the early 1990s.

\section{DICK CREEK: Priority - High Description}

Dick Creek, a 2nd order tributary to lower Monture Creek, flows $\sim 14$ miles through both public (National Forest, State) and private agricultural and industrial forest (Plum Creek) lands. Dick Creek ranks high on the restoration priority list. Although located in a bull trout core area, Dick Creek does not support bull trout spawning and rearing. Its high native species rank results from the presence of fluvial WSCT and a multi-species sports fishery value to the Blackfoot River. It has the potential to increase flow, and ranks high in water quality benefits to Blackfoot River. Dick Creek supports populations of fluvial WSCT, rainbow trout, brown trout, and resident brook trout. Moderate densities of rainbow trout dominate its lower reaches along with brown trout and low densities of brook trout. Dick Creek's headwaters support WSCT and brook trout in moderate densities. Fisheries impairments include: 1) livestock induced stream bank degradation and riparian vegetation suppression, 2) lack of complex fish habitat (instream wood), 3) irrigation impacts (fish entrainment), 4) instream flow (low flow from irrigation withdraws and natural causes), 5) road crossing (culverts limiting fish passage).

\section{TMDL Issues}

Not listed

\section{Dewatering Issues}

The middle reach of Dick Creek (mile 3.5-6.0) is on dewatered stream list due to natural losses and irrigation.

\section{Native Species Issues}

Bull trout core area stream

Isolet WSCT population

WSCT genetic composition: tested 100\% WSCT 


\section{$\underline{\text { Restoration Activities }}$}

\section{Past Restoration}

Dick Creek has substantial amount of restoration work completed, involving channel and wetland restoration and grazing improvements.

Current/Planned Restoration

A turbulent fountain fish screen is to be installed in 2005 .

\section{Monitoring Activities}

Past Monitoring

FWP inventoried fish populations in 1992 and 2001 and measured water temperatures in 1997, 1999 and 2001.

\section{Ongoing Monitoring}

None

\section{Planned Future Monitoring}

None

\section{BEAVER CREEK: Priority - High \\ Description}

Beaver Creek, a $3^{\text {rd }}$ order tributary to Keep Cool Creek located near Lincoln, flows $\sim 9$ miles through both public and private land. The private land is located in the lower three miles of stream. Beaver Creek ranks high for total and biological rank. Supporting very limited bull trout rearing and fluvial WSCT, Beaver Creek ranks high for native species value. In addition to providing a high multi-species sport fishery value, Beaver Creek also ranks high in both 1) potential water quality benefits, and 2) potential to increase flows to the Blackfoot River. Beaver Creek supports high densities of WSCT in headwaters along with brown trout and resident brook trout in lower reaches. Brown trout are dominant at increased densities in lower reaches. Fisheries impairments, located in the middle reaches include: 1) reduced instream flow from irrigation, 2) fish entrapment to irrigation canals, and 3) livestock induced stream bank damage, and 4) riparian vegetation suppression from livestock grazing and an instream corral.

\section{TMDL Issues}

Not listed

\section{Dewatering Issues}

Although irrigation occurs in the middle portion of Beaver Creek, the level of dewatering and fisheries impacts have not yet been evaluated.

\section{Native Species Issues}

WSCT genetic composition: tested 100\% WSCT

\section{Restoration Activities}

\section{Past Restoration}

Improvements on Beaver Creek include fish-friendly diversions and riparian grazing changes. The USFS has implemented projects to reduce sediment delivery to Beaver 
Creek and improve road crossings.

Current/Planned Restoration

None

\section{Monitoring Activities}

Past Monitoring

FWP inventoried fish population surveys in 1989, resurveys sites in 1999 and 2004, and measured stream temperatures in 1999, and 2001-04. FWP tested for whirling disease in Beaver Creek in 2004, the results of which are pending. The USFS conducts periodic McNeil core samples.

Ongoing Monitoring

None

Planned Future Monitoring

Periodic fish sampling and water temperature measurements are expected to continue.

\section{BELMONT CREEK: Priority - High \\ Description}

Belmont Creek, a large $2^{\text {nd }}$ order tributary to the lower Blackfoot River, flows $\sim 11$ miles through public and private land-primarily industrial (Plum Creek) forest. The lower $\sim 10$ miles of stream are Plum Creek properties, except for a BLM section near the mouth. Past fisheries-related projects include a Plum Creek-sponsored basin-wide erosion control (road drainage) measures, along with fish passage improvements near the mouth. As a bull trout core area and fluvial WSCT stream, Belmont Creek ranks high on the restoration priority list for total rank, biological rank, and native species rank. In addition to native species, Belmont Creek supports rainbow and brown in lower reaches and very low brook trout densities. This species assemblage provides for high (multi-species) sport fishery value to the Blackfoot River. With only one of three water quality impairments (sediment), Belmont Creek ranked as a low priority for potential water quality improvements. Fisheries-related impairments include elevated levels of instream sediment (road drainage, riparian livestock access), along with areas of low habitat complexity in lower Belmont Creek. Whirling disease was detected in Belmont Creek in 2003 at a low grade (mean grade 0.38 ).

\section{TMDL Issues}

Listed: yes

Listed causes of impairment: Habitat alterations and siltation.

\section{Dewatering Issues}

None

\section{Native Species Issues}

Bull trout core area stream, proposed critical bull trout habitat, bull trout spawning stream Fluvial WSCT spawning WSCT genetic composition: tested $100 \%$ WSCT

\section{$\underline{\text { Restoration Activities }}$}




\section{Past Restoration}

Twin culverts that seasonally restricted upstream fish movements were replaced in 1990 . Plum Creek Timber Company has initiated a sediment control project. The BLM has recently completed some habitat enhancement and grazing modifications in lower Belmont Creek.

\section{Current/Planned Restoration Activities}

None

\section{Monitoring Activities}

\section{Past Monitoring}

FWP inventoried fish population surveys in 1989 and resurveyed some sites in 1994, 1997, 1998 and 2001, measured stream temperature in 1997-1999 and 2001-2004 and stream flows in 1989 and 2000. FWP tested for whirling disease from 2000 through 2004. Telemetry identified this stream as supporting fluvial WSCT spawning. An ambient water quality survey was completed in 1989 (Ingman et al. 1990).

\section{Ongoing Monitoring}

Annual summer water temperatures are expected to continue.

\section{Planned Future Monitoring}

Period fish population and whirling disease monitoring will continue.

\section{ROCK CREEK: Priority - High \\ Description}

Rock Creek, the largest tributary to the lower North Fork Blackfoot River, is a 2nd order stream that flows 8.2 miles through public (State) and private ranch land. State land is only found in the upper reaches of the stream. Rock Creek ranks high on the restoration priority and total rank list due to: 1) bull trout core area status, and bull trout rearing, 2) fluvial WSCT presence, 3) high (multi-species) sport fishery value, 4) potential to increase flow in the Blackfoot River, and 5) high potential to improve downstream water quality. Rock Creek ranked low for social and financial considerations. Rock Creek contains some rearing of bull trout, fluvial WSCT, brown trout, rainbow trout and resident brook trout. Many of the fisheries impairments were addressed over the last decade. Current fisheries impairments, concentrated in middle reach of Rock Creek drainage, include 1) dewatering, entrainment, fish passage problems related to irrigation, 2) lack of instream complexity, 3) heavily degraded riparian vegetation resulting from excessive livestock access to stream banks. Whirling disease approaching lethal levels is now present at in the watershed.

\section{TMDL Issues}

Listing history: 1996-Yes; 2000-Yes; 2002-Yes; 2004-Yes.

Listed causes of impairment: Habitat and flow alterations, siltation.

\section{Dewatering Issues}

Rock Creek is on dewatered stream list between stream mile 1.4-7.0 due to both natural losses and irrigation.

\section{Native Species Issues}


Bull trout core area stream

Fluvial WSCT migration corridor

\section{Restoration Activities}

Past Restoration

Rock Creek has been the focus of restoration over its entire 8.2-mile length since the early 1990s. Restoration actions include channel and floodplain reconstruction, grazing management, shrub plantings, culvert replacements and instream flow enhancement using a flood to sprinkler conversion.

\section{Current/Planned Restoration}

Restoration focusing on shrub planting and floodplain construction will continue through 2005.

\section{Monitoring Activities}

\section{Past Monitoring}

FWP conducted fish population surveys in 1989, 1990, 1994, 1996, 1998, 1999, 2001, and 2002-2004. FWP completed habitat surveys in 1990 on the lower 1.4 miles of stream (Pierce 1991), and then surveyed the remaining 6.8 miles of Rock Creek in 1998 (Koopal 1999). FWP measured stream flows in 1989 and 2002 and water temperatures in 1998, 1999 and 2002. Whirling disease monitoring has occurred in 1999-2001 and 2003.

\section{Ongoing Monitoring}

Ongoing monitoring includes continued fish population monitoring in lower Rock Creek, and periodic sampling of other sites. Periodic stream temperature and whirling disease monitoring is expected to be ongoing.

\section{Planned Future Monitoring}

In addition to ongoing monitoring, upon completion of all Rock Creek projects, postproject habitat and fish population will likely be undertaken.

\section{GOLD CREEK, West Fork: Priority - High Description}

West Fork Gold Creek is a $2^{\text {nd }}$ order tributary stream to Gold Creek in the lower Blackfoot watershed. Its headwaters begin at Bull Lake and flow 8.0 miles through both public (National Forest) and private industrial (Plum Creek) forestlands. West Fork Gold Creek ranks high in total ranking on the restoration priority list, due to its high native species value and multi-species sport fishery value to the Blackfoot River. It also ranks high in social and financial considerations. Because of its generally high water quality, West Fork of Gold Creek ranks low for providing potential downstream water quality benefits. Because the West Fork does not provide irrigation, there is no potential for improving downstream flows to the Blackfoot River. A bull trout core stream, West Fork Gold Creek supports bull trout spawning and rearing. The lower reaches of the West Fork support low numbers of fluvial WSCT, juvenile bull trout, rainbow trout, brown trout and resident brook trout. Fisheries impairments include road drainage problems.

TMDL Issues

Dewatering Issues 
None

Native Species Issues

Bull trout core area, proposed critical bull trout habitat

WSCT genetic composition: untested

Restoration Activities

Past Restoration

None

Current/Planned Restoration

None

\section{Monitoring Activities}

Past Monitoring

FWP inventoried fish populations in 2000.

Ongoing Monitoring

None

Planned Future Monitoring

None

\section{KLEINSCHMIDT CREEK: Priority - High}

\section{Description}

Kleinschmidt Creek, a 1st order spring creek tributary to Rock Creek (North Fork watershed), drains the southern portion of Kleinschmidt Flat. This stream flows $\sim 2.6$ miles mostly through private land. Kleinschmidt Creek has been the focus of an extensive channel reconstruction and restoration project and is now in early recovery stage. Kleinschmidt Creek ranks high for project streams for all criteria. These high ranks are the result of bull trout core area status, bull trout rearing, and use by fluvial WSCT and multi species sport fishery values. Despite extensive restoration, Kleinschmidt Creek has potential for further water quality improvement with modified riparian grazing practices in upper reaches. Kleinschmidt Creek received a high social rank. Kleinschmidt Creek supports very low densities of juvenile bull trout and fluvial WSCT along with higher densities of brook trout and brown trout. Fisheries impairments limited to upper Kleinschmidt Creek include 1) lack of riparian vegetation, 2) excessive livestock access to the riparian area and 3) feedlot runoff. Kleinschmidt Creek support a high level of whirling disease.

\section{TMDL Issues}

Listing history: 1996-No; 2000-Yes; 2002-Yes; 2004-Yes.

Listed causes of impairment: metals (copper), thermal modification, fish habitat degradation, other habitat alterations, and riparian degradation.

\section{Dewatering Issues}

None in lower spring-fed portion of Kleinschmidt Creek.

\section{Native Species Issues}


Bull trout core area

No evidence of WSCT reproduction

\section{Restoration Activities}

\section{Past Restoration}

Complete channel reconstruction of the lower 1.5 miles of stream ending in 2001 Restoration objectives including reducing whirling disease infection levels, restoring stream channel morphology for all life stages of trout, increasing recruitment of trout to the Blackfoot River, and restoring thermal refugia and rearing areas for North Fork bull trout. Restoration activities included decreasing the width to depth ratio, restoring channel sinuosity, creation of pools, addition of woody debris and other natural materials to the channel, shrub plantings along streambank, creation of riparian wetlands, and livestock fencing.

\section{Current/Planned Restoration}

Grazing management changes are planned for the upper reach Kleinschmidt Creek.

\section{Monitoring Activities}

\section{Past Monitoring}

FWP assessed habitat in 1990 and 2002, surveyed fish populations beginning in 1990 and periodically through 2004. FWP measures stream temperatures in 1998, 1999 and 20012004. FWP conducted whirling disease testing between 1997 and 2003.

\section{Ongoing Monitoring}

FWP plans to continue fish population, water temperature and whirling disease studies into the next few years.

\section{Planned Future Activities}

Planned monitoring associated with 2005 restoration program included macroinvertebrate sampling, water quality sampling (nutrients, TSS), water temperature monitoring, and habitat/geomorphic/riparian assessments. Periodic fish population surveys will likely continue.

\section{DUNHAM CREEK: Priority - High \\ Description}

Dunham Creek, a large 2nd order tributary to Monture Creek, flows $\sim 13$ miles through public land (National Forest) and a small portion of private land near the mouth. Dunham Creek ranks high on the restoration priority list for project streams. Supporting fluvial bull trout spawning and rearing and fluvial WSCT, Dunham Creek ranks high in native species and multi-species sport fishery values. Because of existing high water quality, Dunham Creek has low potential water quality benefits. Dunham Creek supports populations of fluvial bull trout, fluvial WSCT, and resident brook trout. Fish densities for both WSCT and bull trout decline in the middles reaches. Fisheries impairments, located in the middle and lower reaches, include the loss of riparian vegetation related to past logging practices. Dunham Creek is also site of an extensive channel reconstruction, habitat restoration and revegetation project. Dunham Creek is in the early stages of project recovery.

\section{TMDL Issues}


Not listed

\section{Dewatering Issues}

The lower five miles of Dunham Creek are on dewatered stream list due to natural losses and some irrigation within the natural losing reach.

\section{Native Species Issues}

Bull trout core area, proposed critical bull trout habitat, bull trout spawning

Fluvial WSCT spawning

WSCT genetic composition: tested $100 \%$ WSCT

\section{Restoration Activities}

\section{Past Restoration}

In 1996, the Dunham ditch was screened to prevent fish losses to the ditch. The diversion was then upgraded improve upstream low flow fish passage in 2003-04.

In the 1970's over a mile of Dunham Creek was channelized. In 2001, the Blackfoot cooperators reconstructed this stream section to natural channel dimensions, which include restoring features to a reference condition and aggressive revegetation. The project involved correcting sediment deliveries estimated at $\sim 25$-times natural levels. This influx of unnaturally high levels of sediment entered the channel immediately upstream of the Dunham Creek bull trout spawning area

\section{Current/Planned Restoration}

None

\section{Monitoring Activities}

\section{Past Monitoring}

Beginning in 1995, telemetry identified this stream as a fluvial bull trout and WSCT spawning stream, and identified the Dunham diversion as a native fish entrainment problem. FWP conducted fish population surveys in 1996, 1998, and 2000-2004 and began bull trout redd counts in 2002. FWP performed geomorphic, McNeil core and winter water temperature data collections in fall of 2004 in a section of the restored reach used by spawning bull trout. FWP observed bull trout redds in project area in 2002 and 2004.

\section{Ongoing Monitoring}

Fish population surveys in the reach affected by restoration activities.

\section{Planned Future Monitoring}

None beyond ongoing monitoring

\section{GOLD CREEK: Priority - High}

\section{Description}

Gold Creek, a large 3rd order tributary to the lower Blackfoot River, flows $\sim 19$ miles through public (National Forest, BLM) and private industrial forest (Plum Creek) land. Gold Creek ranks high on the restoration priority list. As a core area bull trout stream, Gold Creek provides spawning and rearing of fluvial bull trout. Gold Creek also supports fluvial WSCT and rainbow trout and brown trout in lower reaches along with resident brook trout. Gold Creek ranks high in native species value and provides high (multi- 
species) sport fishery value. Because of generally high water quality, Gold Creek ranked low for potential water quality benefits. Gold Creek provides no irrigation and thus no potential to improve downstream flows to the Blackfoot River. Fisheries impairments include: 1) road drainage problems, 2) recreational impacts (access sites in bull trout spawning areas) and 3) low whirling disease infection. Gold Creek tested positive for whirling disease with a very low grade in 1999 and tests since have been negative.

\section{TMDL Issues}

Not listed

\section{Dewatering Issues}

None

\section{Native Species Issues}

Bull trout core area, proposed critical bull trout habitat, bull trout spawning, bull trout recovery/recreational conflict area

Fluvial WSCT spawning WSCT genetic composition: tested $99 \%$ WSCT

\section{$\underline{\text { Restoration Activities }}$}

\section{Past Restoration}

Past harvest of riparian conifers combined with the actual removal of large woody debris from the channel has reduced habitat complexity in the lower three miles of Gold Creek. Before 1996, pools accounted for less than $1 \%$ of the wetted surface area in this section of stream (Pierce 1990). Low densities of age 1+ fish, including native fish, resulted from this habitat simplification. In 1996, the Blackfoot cooperators installed 66 habitat structures made of native material (rock and wood) that resulted in 61 new pools in the 3mile section.

\section{Current/Planned Restoration}

None

\section{Monitoring Activities}

\section{Past Monitoring}

FWP inventoried fish populations in 1989, and monitored fish population response related to a habitat enhancement project between 1996 and 2003. A journal paper was also published relating the survival of habitat structures to a flood event (Schmetterling and Pierce 1999). FWP measured stream temperatures between 1999 and 2004 and stream flows in 1989 and 2000. Whirling disease testing was conducted in 1997, 19992000 and 2002. Telemetry identified this stream as a fluvial WSCT spawning stream. An ambient water quality survey was completed in 1989 (Ingman et al. 1990).

\section{Ongoing Monitoring}

Periodic fish population, water temperature and whirling disease sampling are ongoing.

Planned Future Monitoring

None beyond periodic/ongoing monitoring.

SNOWBANK CREEK: Priority - High 


\section{Description}

Snowbank Creek is a $1^{\text {st }}$ order tributary stream to Copper Creek, an important spawning and rearing stream for WSCT and fluvial bull trout in the upper Blackfoot River watershed. Snowbank Creek's headwaters begin on the eastern slope of Stonewall Mountain then flow northeast 4.4 miles through the Helena National Forest before entering Copper Creek at mile 5.9. Snowbank Creek ranks high in the total ranking due to high native species value, including bull trout core area and rearing present, high social and financial rank and ability potential to provide increased flows to the Blackfoot River. Human-related fisheries impairments involve a defunct diversion structure. Impairments are: 1) fish entrainment to Snowbank Lake, 2) reduced fish passage, 3) stream channel dewatering below the diversion, 4) localized channel alterations in the area of the diversion, and 5) a road crossing identified as a partial fish passage barrier.

\section{TMDL Issues}

Not listed

\section{Dewatering Issues}

The lower 0.4 miles of Snowbank Creek is on the dewatered stream list due to a diversion to Snowbank Lake, which diverts a majority of the Snowbank Creek base to Snowbank Lake.

\section{Native Species Issues}

Bull trout core area stream

WSCT genetic composition: untested

\section{Restoration Activities}

\section{Past Restoration}

None

\section{Current/Planned Restoration}

The existing diversion to Snowbank Lake results in several fisheries problems. In addition, the water diverted for the stream has no legal water right. Planning to correct these problems is ongoing. Wildfire-related restoration work including cross-drainage improvements on roads and upsized culvert replacements are planned for 2005.

\section{Monitoring Activities}

\section{Past Monitoring}

FWP conducted fish population surveys in 2003 and 2004 and measured stream and ditch flows in 2003. Initial McNeil core sampling of cutthroat spawning gravels has been conducted by the USFS and several more years of sampling is planned.

\section{Ongoing Monitoring}

Flow and fish population monitoring is expected to continue.

\section{Planned Future Monitoring}

Monitoring and planning is ongoing.

\section{BLANCHARD CREEK: Priority - High \\ Description}


Blanchard Creek, a 2nd order tributary to the lower Clearwater River, flows $\sim 13$ miles through industrial (Plum Creek) forest, along with State land and private agricultural properties in lower reaches. Blanchard Creek ranks high for both total and biological rank, based largely on its potential for instream flow and water quality benefits. Because Blanchard Creek supports fluvial WSCT but no bull trout, it ranks moderate in native species value. However, because Blanchard Creek supports high rainbow trout densities and brown trout, it ranks high (multi-species) sport fishery value to both the Clearwater and Blackfoot Rivers. Fisheries-related impairments - located primarily in lower Blanchard Creek include 1) dewatering, 2) channel alterations, 3) road drainage problems, 4) livestock induced stream bank degradation and 5) riparian vegetation suppression.

\section{TMDL Issues}

Listing history: 1996-Yes; 2000-Yes; 2002-Yes; 2004-Yes.

Listed causes of impairment: Habitat alterations, siltation, and flow alteration.

\section{Dewatering Issues}

The lower 1.2 miles of Blanchard Creek is on the dewatering stream list due to irrigation.

\section{Native Species Issues}

WSCT genetic composition: tested 78\% WSCT

\section{$\underline{\text { Restoration Activities }}$}

\section{Past Restoration}

Past restoration involved the installation of diversions with fish ladders and enhancement of flows between 1990 and 2002. Some grazing improvements have been implemented on State lands.

\section{Current/Planned Restoration}

None

\section{Monitoring Activities}

\section{Past Monitoring}

FWP conducted fish population surveys in 1990, 1992-1995, 1997-2000 and 2002-2003 and measured stream temperatures in 1999 and 2001. An ambient water quality survey was completed in 1989 (Ingman et al. 1990).

\section{Ongoing Monitoring}

None

\section{Planned Future Monitoring}

Periodic fish population sampling will likely continue.

\section{COPPER CREEK: Priority - High}

\section{Description}

Copper Creek, a large 3rd order tributary to the Landers Fork in the upper Blackfoot River watershed, flows $\sim 14$ miles entirely through public (National Forest) land, except a small portion of private land in the lower reaches. Copper Creek ranks high on the restoration priority list. With bull trout core area status, fluvial bull trout and genetically 
pure fluvial WSCT spawning and rearing, it ranks high in native species value and high (multi-species) in sport fishery value to the Blackfoot River. Because of existing high water quality and adequate flows, Copper Creek ranks low in potential water quality benefits to the Blackfoot River. Densities of WSCT and bull trout for both species are generally low throughout the drainage, but increase in middle reaches. Fisheries impairments include stream crossing (fords and undersized bridges) and localized areas of stream bank degradation from recreational users in the middle. Dewatering in Snowbank Creek, a tributary to Copper Creek, may affect instream flows.

\section{TMDL Issues}

Not listed

\section{Dewatering Issues}

The lower mile of Copper Creek is on the dewatered stream list due to natural dewatering and other areas in the headwaters are naturally intermitted the extent of which is unknown. How flows in Copper Creek are affected by flow reductions in Snowbank Creek is unknown.

\section{Native Species Issues}

Bull trout spawning stream, proposed critical habitat, bull trout core area, bull trout recovery/recreational conflict area

Fluvial WSCT spawning WSCT genetic composition: tested $100 \%$ WSCT

\section{Restoration Activities}

\section{Past Restoration}

None

\section{Current/Planned Restoration}

The USFS is planning road obliteration, reducing sediment delivery and replacing culverts at several locations within the watershed.

\section{Monitoring Activities}

\section{Past Monitoring}

FWP inventoried fish population in 1989 and resurveyed sites in 1998-1999, 2002 and 2004. FWP measured water temperatures 1999 and 2001-2004 and stream flows in 1989 and 2000. Annual bull trout redd counts conducted by the USFS began in 1988. The USFS has collected several years of McNeil core sample data. Telemetry identified this stream as an important fluvial WSCT spawning stream.

\section{Ongoing Monitoring}

Bull trout redd counts occur annually in Copper Creek, bull trout spawning site assessments will be completed by 2005. Periodic fish population surveys at established sites are expected to continue.

Planned Future Monitoring

None beyond ongoing/periodic surveys.

WARREN CREEK: Priority - High 


\section{Description}

Warren Creek, a small 2nd tributary to the middle Blackfoot River, flows $\sim 14$ miles primarily through forested foothills and private ranch land. Warren Creek ranks high on the restoration priority and total rank list. This high rank is due to high (multi-species) sport fishery value to the Blackfoot River and high potential to improve downstream flow and water quality. Warren Creek has a moderate native species value. Warren Creek contains a mixed species composition of brook trout, brown trout and low numbers of WSCT. Brook trout inhabit the entire drainage, brown trout are found in the lower reaches and WSCT are present in the lower and upper reaches of Warren Creek. Fisheries impairments, located throughout the drainage, include: 1) road crossings, 2) irrigation dewatering and diversion that inhibit fish passage, 3) channelization, 4) lack of instream complexity, and 5) degraded stream banks and riparian areas due to excessive livestock access. Warren Creek tested positive for whirling disease in 1998.

\section{TMDL Issues}

Listing history: 1996-Yes; 2000-Yes; 2002-Yes; 2004-Yes.

Listed causes of impairment: Flow and habitat alterations.

\section{Dewatering Issues}

The lower six miles of Warren Creek is on the dewatered stream list to irrigation.

\section{Native Species Issues}

WSCT genetic composition: untested

No evidence of WSCT reproduction

\section{Restoration Activities}

\section{Past Restoration}

Warren Creek has been the focus of extensive restoration efforts beginning in 1991 .

Projects to date include 1) removal of three streamside corrals, 2) improved fish passage at three locations, 3) three miles of channel reconstruction, 4) six miles of improved riparian grazing, and 5) enhanced stream flows in the lower three miles of stream.

\section{Current/Planned Restoration}

Approximately one mile of Warren Creek is currently being reconstructed. Shrub planting and riparian grazing changes will be incorporated.

\section{Monitoring Activities}

\section{Past Monitoring}

FWP conducted fish population surveys in 1991, 1992, 1997, and 2000-2004 measured stream flows in 2000, stream temperatures in 2000-2004 and conducted whirling disease tests in 1997-2000.

\section{Ongoing Monitoring}

Fish population, water temperatures and whirling disease monitoring are expected to continue into the next few years.

\section{Planned Future Monitoring}

None, beyond ongoing fish population surveys. 


\section{WILLOW CREEK (lower): Priority - High \\ Description}

Willow Creek below Lincoln, a 2nd order tributary to the upper Blackfoot River, flows $\sim 9$ miles through public (National Forest) land in the upper drainage and private ranch land downstream of mile $\sim 6$. Willow Creek ranks high for restoration priority and total rank, due to: 1) high potential to improve water quality to the Blackfoot River, 2) moderate native species value, 3 ) high (multi-species) sport fishery value to the Blackfoot River, and 4) potential to increase flows in the Blackfoot River. Willow Creek supports fluvial WSCT, brown trout and resident brook trout. WSCT and brook trout dominate upper reaches. Low densities of brown trout occupy lower Willow Creek. Fisheries impairments include culverts and mining in the upper drainage as well as irrigation dewatering and degraded riparian vegetation from excessive livestock use in the middle and lower reaches.

\section{TMDL Issues}

Not listed

\section{Dewatering Issues}

The lower two miles of Willow Creek is on the dewatered stream list due to irrigation.

\section{Native Species Issues}

WSCT genetic composition: tested $100 \%$ pure

\section{$\underline{\text { Restoration Activities }}$}

Past Restoration

None

Current/Planned Restoration

None

\section{Monitoring Activities}

\section{Past Monitoring}

FWP inventoried fish population in 1992 and 1999, measured stream temperatures in 1999 and from 2001-2003 and stream flows in 2000.

\section{Ongoing Monitoring}

None

\section{Planned Future Monitoring}

None

\section{ELK CREEK: Priority - High Description}

Elk Creek, a degraded 3rd order tributary to the lower Blackfoot River, flows $\sim 14$ miles through both public (BLM and State) in headwaters and private (agricultural) land in lower $\sim 7$ miles. It ranks high on the restoration priority list as it has a high potential for improving water quality and downstream flows to the Blackfoot River. Elk Creek provides a high (multi-species) sport fishery value to the Blackfoot River, but ranked moderate in native species value and received a low social and financial ranking. Elk 
Creek supports populations of fluvial WSCT, rainbow trout, brown trout, and resident brook trout. Densities of all species decrease in the downstream direction. Fisheries impairments in upper Elk Creek include channel alterations (placer mining) and road drainage problems. Fisheries impairments for lower Elk Creek include: 1) lack of complex fish habitat (instream wood), 2) livestock induced stream bank degradation and riparian vegetation suppression, 3) elevated water temperature and channel instability, 4) irrigation impacts (instream flows, fish losses to ditches and fish passage), and 5) adverse effects of upstream mining and road drainage problems. Elk Creek tested positive for whirling disease in 2003 with a mean grade of 2.84 .

\section{TMDL Issues}

Listed

\section{Dewatering Issues}

The lower three miles of Elk Creek is on the dewatered stream list due to irritation.

\section{Native Species Issues}

WSCT genetic composition: tested 94\% WSCT

\section{Restoration Activities}

\section{Past Restoration}

To begin improving water quality in lower Elk Creek, a major erosion control project was undertaken in a channelized section of lower Elk Creek (mile 1.3-2.9) in 1994. This project included the reconstruction of 8,600' of new channel as well as some livestock management changes. Although this project corrected a major sediment problem, subsequent monitoring of water temperature, fish populations, and suspended sediment all confirm Elk Creek failed to meet intended project benefits. Objectives were not met, as grazing prescriptions were not followed. Other grazing plans on adjacent riparian pastures were not implemented.

\section{Current/Planned Restoration}

FWP is currently working with the Blackfoot Challenge and NRCS to again develop restoration and grazing plans for the lower four miles of Elk Creek

\section{Monitoring Activities}

\section{Past Monitoring}

FWP 1) conducted fish population surveys in 1989, 1991, 1995-1997, 2000 and 2003, 2) monitored water temperatures in 1997 and 1999-2003,3) measured stream discharge in 2000 and 2003, 4) measured total suspended sediment in 2001, 5) performed geomorphic surveys at two locations in 2004, and 6) began monitoring for whirling disease in 1997 and continued in 1999 and 2000-2004. An extensive geomorphic, fish habitat and riparian habitat study was completed over the length of the mainstem (Watershed consulting 1996). An ambient water quality survey was completed in 1989 (Ingman et al. 1990).

\section{Ongoing Monitoring}

Periodic monitoring of fish populations, water temperature and whirling disease will continue. 


\section{Planned Future Monitoring}

Additional monitoring will depend upon outcomes of the current restoration planning efforts.

\section{HOYT CREEK: Priority - High \\ Description}

Hoyt Creek, a small 1st order spring creek tributary to lower Dick Creek, originates from alluvial aquifers located immediately north of Ovando. This spring creek flows $\sim 4$ miles exclusively through private ranch land. Despite a low native species rank, Hoyt Creek ranks high in the restoration and total rank priority list. This rank is due to high (multispecies) sport fishery value and potential to improve flow and water quality in the watershed. Hoyt Creek supports WSCT, rainbow trout, brown trout and brook trout in generally low densities. Fisheries impairments, located throughout the stream, include channel instablity, lack of habitat complexity, irrigation dewatering and suppressed riparian vegetation.

\section{TMDL Issues}

Not listed

\section{Dewatering Issues}

Approximately one mile of Hoyt Creek is on the dewatered stream list due to irrigation.

\section{Native Species Issues}

Bull trout core area stream

No known WSCT reproduction in the stream

\section{Restoration Activities}

\section{Past Restoration}

Grazing management changes, diversion upgrades and culvert to bridge replacements.

\section{Current/Planned Restoration}

The reconstruction of an incised portion of Hoyt Creek is being considered.

\section{$\underline{\text { Monitoring Activities }}$}

\section{Past Monitoring}

FWP inventoried fish populations in 1992 and measured stream temperatures at two locations in 2001. Geomorphic assessments were completed in 2003 and 2004.

\section{Ongoing Monitoring}

None

\section{Additional Planned Monitoring}

Additional monitoring will be necessary depending on outcome of current restoration planning.

\section{SPRING CREEK (North Fork): Priority - High \\ Description}

Spring Creek, a small 1st tributary to the North Fork Blackfoot River, originates on the north side of Ovando Mountain. It flows $\sim 6$ miles through private land. Spring Creek 
ranks high on the restoration priority and total rank list due to a high native species rank, high (multi species) sport fishery value, and a potential to increase flows in the Blackfoot. Located in the bull trout core area, Spring Creek supports juvenile bull trout rearing, and low densities of fluvial WSCT and brook trout. Fisheries impairments include dewatering and fish losses to an irrigation ditch.

\section{TMDL Issues}

Not listed

\section{Dewatering Issues}

The lower 6.5 miles of spring creek in on dewatered stream list due to irrigation.

\section{Native Species Issues}

Bull trout core area stream

WSCT genetic composition: tested $97 \%$ WSCT

\section{Restoration Activities}

\section{Past Restoration}

The restoration of spring Creek began in 1998 with the installation of a diversion retrofitted with a fish ladder at mile 1.8. A baffled culvert replaced an undersized culvert at mile 0.5 in 1998 in order to improve upstream juvenile bull trout passage.

\section{Current/Planned Restoration}

Water conservation projects and irrigation ditch fish screening options are currently in the development phases.

\section{Monitoring Activities}

\section{Past Monitoring}

FWP conducted fish population surveys in 1997, 2000 and 2002. Stream flows were monitored by FWP in 2000 and BBCTU in 2003.

\section{Ongoing Monitoring}

\section{None}

\section{Planned Future Monitoring}

Fish population surveys and flow monitoring are expected to continue on a periodic basis one the instream flow and fish screening projects are complete.

\section{BLACKFOOT RIVER (Reach 1: Headwaters to Lincoln): Priority - High Description}

The Blackfoot River begins on south-western slopes of the Continental Divide at river mile 132.5. This headwater reach begins as a small $2^{\text {nd }}$ order stream at the confluence of Beartrap and Anaconda Creeks and extends 23.6 miles to the Lincoln (mile 108.9). It flows through private (Sieben Ranch Co, Plum Creek, privately owned) and public (National Forest, State) lands. Four larger basin-fed tributaries (upper Willow Creek, Alice Creek, Hogum Creek and the Landers Fork) feed this section of the river. These tributaries all support WSCT, usually brook trout and low densities of brown trout in lower reaches. Many other smaller tributaries not described in this report also support fisheries. The Landers Fork is the largest tributary and increases the Blackfoot River to a 
$4^{\text {th }}$ order stream. Copper Creek, the largest tributary to the Landers Fork is the primary fluvial bull trout-spawning stream for the upper Blackfoot Watershed. This reach supports limited mainstem spawning by bull trout, WSCT and brown trout. This reproduction contributes to its high native species value and overall high total ranking on the restoration priority list. The effects of mining contamination remain the most serious threat to fish populations in this reach. Other mainstem fisheries impairments include: 1) instream flow limitations resulting primarily from natural stream losses with some irrigation in the lower portion of the reach, 2) channel alterations, 3) lack of instream wood, and 4) fish losses to an irrigation ditch. Whirling disease is also increasing in this reach.

\section{TMDL Issues}

Listed

\section{Dewatering Issues}

The lower portion of this reach is dewatered due to natural stream losses and irrigation to a limited degree.

\section{Native Species Issues}

Bull trout nodal habitat, proposed critical bull trout habitat

WSCT migration corridor

WSCT genetic composition: tested $99-100 \%$ WSCT

\section{$\underline{\text { Restoration Activities }}$}

\section{Past Restoration}

Some mine reclamation work has been completed

\section{Current/Planmed Restoration}

Cleanup of toxic sites is planned on the national forest

\section{Monitoring Activities}

\section{Past Monitoring}

FWP established several fish population survey sections in this reach in the 1970s, which were periodically surveyed through 1999 . Water quality and macro-invertebrates were assessed at three locations in 1988-89 (Ingman et al. 1990). A riparian health inventory was conducted in 1999 (Marler and Schmetterling). In 2000, FWP conducted a habitat survey of the lower 12 miles of this reach with an emphasis on pool size, pool frequency, a large wood inventory, bankfull measurements, pebble counts, flow and water temperature measurements. FWP tested for whirling disease from 1998 through 2004. The USFS periodically collects McNeil core samples in this reach.

\section{Ongoing Monitoring}

FWP conducts periodic (4-10 year interval) fish population surveys and monitors summer water temperature data and whirling disease samples on an annual basis.

\section{Planned Future Monitoring}

None beyond periodic monitoring.

\section{BLACKFOOT RIVER (Reach 2: Lincoln to Arrastra Creek): Priority - High}




\section{Description}

This 20.1-mile reach of the upper Blackfoot River extends from Lincoln (mile 108.9) to Arrastra Creek (mile 88.8). It begins in an intermittent reach where the mainstem gains large volumes of groundwater and spring creek inflows during base-flow periods. Landownership consists of private and mixed public (National Forest, BLM and State) lands. Several basin-fed tributary streams enter this section of the Blackfoot (Poorman Creek Keep Cool Creek, Lincoln Gulch, lower Willow Creek, Sauerkraut Creek, Little Moose Creek, and Moose Creek), all supporting WSCT populations, as well as other salmonids depending on the specific stream. This gaining section of the river provides concentrated spawning areas for brown trout and very limited bull trout reproduction. Brown trout is the dominant species, followed by low, but increasing numbers of WSCT and very low bull trout densities, all of which contribute to its high ranking for native species value and multi-species sport fishery value. Overall, this reach ranks high in total ranking on restoration priority list. Fisheries impairments include: 1) localized lack of in complexity, 2) localized areas of historic and current livestock grazing involving on riparian vegetation and stream bank degradation, and 3) an increasing level of whirling disease.

\section{TMDL Issues}

Listed

\section{Dewatering Issues}

Natural dewatering occurs in the upper-most portion of this reach. There are no human related-dewatering issues on this mainstem reach per se.

\section{Native Species Issues}

Bull trout nodal habitat, proposed critical bull trout habitat

\section{$\underline{\text { Restoration Activities }}$}

\section{Past Restoration}

Riparian grazing management changes and localized streambank stability projects have been implemented.

\section{Current/Planned Restoration}

None

\section{Monitoring Activities}

\section{Past Monitoring}

FWP established the Canyon fish population survey section in the early 1970's and has periodically sampled this section. FWP completed several juvenile fish population surveys in 1998. A riparian health inventory was conducted in 1999 (Marler and Schmetterling. A baseline habitat survey and native fish telemetry study was completed in 2003-04. FWP tested for whirling disease between 1998 and 2002 and in 2004. Water quality and macro-invertebrates were assessed at two locations in 1988-89 (Ingman et al. 1990). The USFS conducts periodic McNeil core samples near the Nevada Ogden Bridge.

\section{Ongoing Monitoring}


FWP conducts periodic fish population surveys in the Canyon section, along with annual monitoring of summer water temperatures and whirling disease samples.

\section{Planned Future Monitoring}

At this time, FWP no additional surveys beyond periodic monitoring activities.

\section{BLACKFOOT RIVER (Reach 4: Nevada Creek to the North Fork): Priority - High Description}

This reach extends 13.7 miles from the mouth of Nevada Creek (mile 67.7) downstream to the mouth of the North Fork Blackfoot River (mile 54). It flows mostly through private ranch with only $\sim 0.8$ mile flanked by public (State) lands on the south side at the lower portion of the reach. Below Nevada Creek, the river becomes more confined by moraine where channel gradient increases and sinuosity decreases. This reach is naturally subject to anchor-ice formation and high accumulations of fine sediment in the substrate. In addition to Nevada Creek, three small tributary streams (Yourname, Wales and Frazier Creeks) enter this reach, all of which are fisheries impaired. The sum of mainstem and tributary impairments result in very low mainstem salmonid densities. This reach ranks high in total ranking due to its high potential for improving water quality and increasing downstream flows and high in native species value, despite low rank for sport fishery value resulting from a lack of mainstem recruitment. Humaninduced mainstem fisheries impairments include: 1) water quality problems originating from Nevada Creek involving elevated nutrients, 2) low summer flows, 3) high summer water temperatures, and 4) livestock suppressed riparian vegetation and stream bank degradation. Whirling disease is also increasing in this reach.

\section{TMDL Issues}

Listed

\section{Dewatering Issues}

The entire 13.7-mile reach is listed on the dewatered stream list due to mainstem irrigation and dewatering of all tributaries entering this reach.

\section{Native Species Issues}

Bull trout nodal habitat, proposed critical bull trout habitat

\section{$\underline{\text { Restoration Activities }}$}

\section{Past Restoration}

Riparian grazing management improvements have occurred in this reach.

\section{Current/Planned Restoration}

None

\section{Monitoring Activities}

\section{Past Monitoring}

FWP established Raymond Bridge fish population survey section and a water temperature monitoring sites in this reach in 1988. In 2002, FWP moved the fish population surveys immediately upstream and renamed the survey site the Wales Creek section. FWP monitors populations in this reach on a bi-annual basis. Water quality and macro- 
invertebrates were assessed at four locations in 1988-89 (Ingman et al. 1990). A riparian heath assessment was completed in 1999 (Marler and Schmetterling 1999). FWP completed a habitat survey was completed for this reach in 2003. FWP measured whirling disease infection levels from 1998 through 2004.

\section{Ongoing Monitoring}

FWP expects to monitor fish populations in the Wales Creek section bi-annually, summer water temperatures annually and whirling disease on a periodic basis.

\section{Planned Future Monitoring}

None beyond ongoing monitoring activities.

\section{MCCABE CREEK: Priority - High \\ Description}

McCabe Creek, a small, 2nd order tributary to Dick Creek, flows $\sim 9.5$ miles through public (National Forest) and private (agricultural) land in middle to lower reaches. McCabe Creek ranked high on the restoration priority and total rank list due to a high native species rank, high biological rank, single species (WSCT) sport fishery value and low potential to improve water quality due to its restored condition. McCabe Creek, located in the bull trout core area, contains fluvial WSCT and brook trout. McCabe Creek has been the focus of a concerted restoration project that included a culvert upgrade, instream flow enhancement, elimination of irrigation ditch fish losses, instream habitat enhancement and riparian grazing changes. Except for suppressed riparian woody vegetation, the majority of fisheries impairments have been addressed through an extensive restoration program. The stream is currently in a recovery phase although grazing impairments continue.

\section{TMDL Issues}

Not listed

\section{Dewatering Issues}

Lower McCabe was a dewatered stream in lower reaches due to irrigation; however, water conservation measures have improved flows resulting in the removal of $\mathrm{McCabe}$ Creek from the dewatered stream list.

\section{Native Species Issues}

Bull trout core area stream

WSCT genetic composition: tested $98 \%$ WSCT

\section{Restoration Activities}

\section{Past Restoration}

A comprehensive restoration project for McCabe Creek began in 1999 and was completed in 2001. This project 1) consolidated four irrigation ditches into one pipeline and screened the intake; 2) converted flood to sprinkler irrigation; 3) restored habitat conditions including the placement of instream wood and shrub plantings along $1 / 2$ mile of stream; 4) incorporated necessary riparian livestock management changes; and 5) improved a county road crossing. In 2001, the project completed the irrigation conversion, developed off-stream livestock watering and reconstructed $\sim 1 / 2$ mile of 
stream channel.

\section{Current/Planned Restoration}

None

\section{Monitoring Activities}

\section{Past Monitoring}

FWP conducted fish population surveys in 1992, 1995, 1997, and 1999-2004 and measured stream temperatures in 1998 and 2001.

\section{Ongoing Monitoring}

Fish population monitoring is approaching final monitoring phases.

\section{Planned Future Monitoring}

None, although a grazing monitoring plan should be initiated.

\section{ALICE CREEK: Priority - High Description}

Alice Creek, an upper Blackfoot River $2^{\text {nd }}$ order tributary, flows $\sim 16$ miles through mixed public (National Forest) and private ranch land. The lower $\sim 3$ miles of stream is exclusively private. Alice Creek ranks high on the restoration priority list and high in native species value as it supports very limited bull trout spawning and rearing, and populations of fluvial WSCT and brook trout. Alice Creek also ranked high on the biological priority list, but provides a low (single species) sport fishery value to the Blackfoot River and ranks low in potential water quality benefits. Recent fish population sampling found no fish in lower Alice Creek and low densities of WSCT in middle reaches. The upper reaches support low densities of WSCT and brook trout. Fisheries impairments near mile two include: 1) the lack of complex fish habitat (instream wood), 2) localized stream banks degradation and 3) an instream road crossing from recreational users. Sections of Alice Creek are seasonally intermittent.

\section{TMDL Issues}

Not listed

\section{Dewatering Issues}

The middle reaches of Alice Creek are seasonally intermittent, the extent of which is unknown

\section{Native Species Issues}

Historic bull trout spawning stream

WSCT genetic composition: tested $100 \%$ WSCT

\section{Restoration Activities}

\section{Past Restoration}

The USFS has undertaken culvert removal in the headwaters, road closure and obliteration, two constructed ford installations and graveling of the Alice Creek road. Riparian shrub plantings were conducted in along the middle reaches in 2002.

\section{Current/Planned Restoration}


None

\section{Monitoring Activities}

\section{Past Monitoring}

FWP inventoried fish populations in 1999 and measured stream temperatures in 1999, 2001 and 2003 and stream flow in 2000. An ambient water quality survey was completed in 1989 (Ingman et al. 1990). The USFS conducted bull trout redd surveys in lower Alice Creek from 1999 to 2003.

\section{Ongoing Monitoring}

None

Planned Future Monitoring

None

\section{CHAMBERLAIN CREEK: Priority - High Description}

Chamberlain Creek, a 2nd order tributary to the middle Blackfoot River, flows 10 miles through both public (BLM) and private (Plum Creek and agricultural) lands. Private land is located in the lower seven miles of stream. Chamberlain Creek ranked high for restoration and total priorities and moderate for biological ranking. This moderate biological ranking is the result of improved flow and water conditions related to past restoration projects. Because Chamberlain Creek supports bull trout rearing and fluvial WSCT, it ranked high in native species value. Chamberlain Creek also supports a multispecies sport fishery value to the Blackfoot River. WSCT dominate the lower four miles along with low numbers of rainbow, brown, brook and bull trout. Fisheries impairments, located in the mid-to lower reaches include: 1) elevated stream sediment (road drainage), 2) livestock induced riparian vegetation suppression, 3) lack of complex fish habitat (instream wood), and 4) dewatering. Whirling disease was first detected in Chamberlain Creek in 1999 and infection had increased to a mean grade of 2.63 in 2002.

\section{TMDL Issues}

Listing history: 1996-Yes; 2000-No; 2002-No.

Listing causes of impairment: Flow alteration, habitat alteration, suspended solids.

\section{Dewatering Issues}

The lower mile of Chamberlain Creek is on the dewatered stream list due to a diversion. A water lease is currently in place for $50 \%$ of the basin discharge, which maintains a minimal level of base flows.

\section{Native Species Issues}

Bull trout rearing

Fluvial WSCT spawning stream

WSCT genetic composition: tested 97-98 \% WSCT

\section{Restoration Activities}

\section{Past Restoration}


Since 1990, Chamberlain Creek has been the focus of a comprehensive fisheries restoration effort. Projects include: road drainage repairs, riparian livestock management changes, fish habitat restoration, irrigation upgrades (consolidate ditches, water conservation, eliminate fish entrainment, fish ladder installation on a diversion), and improved stream flows through water leasing. Restoration occurred throughout the drainage but focused mostly in the lower mile of stream.

\section{Current/Planned Restoration}

None

\section{Monitoring Activities}

\section{Past Monitoring}

FWP inventoried fish populations in 1989, and resurveyed sampling sites in 1995, 1997, 1998, 2000 and 2002-2004. FWP completed a habitat survey in 1990. BLM flow monitoring occurs upstream of the West Fork. FWP measured water temperatures from 1999 through 2004 and stream flow in 1989 and 2000. FWP monitors two staff gauges associated with a water lease in the lower mile of stream. FWP began testing for whirling disease in 1997 and continued from 1999 through 2004. Telemetry identified this stream as an important WSCT spawning stream.

\section{Ongoing monitoring}

Fish population, whirling disease and flow monitoring related to the water lease are ongoing.

\section{Planned Future Monitoring}

FWP plans to evaluate instream sediment levels using McNeil core samples beginning in 2005.

\section{MCELWAIN CREEK: Priority - High \\ Description}

McElwain Creek, a 2nd order tributary to lower Nevada Creek, flows 9 miles through public (BLM) and private ranch land. Private land is located in the lower 6 miles of the stream. McElwain Creek ranks high on the restoration priority and total rank list due to its potential to increase flows in the Blackfoot river and high potential to improve water quality due to its degraded condition. McElwain received a low native species value as it lacks bull trout single species, but does support pure resident WSCT with densities decreasing in the downstream direction. Fisheries impairments, located mostly on private land, include 1) poor road crossings and drainage, 2) irrigation impacts (fish passage and dewatering), 3) degraded riparian vegetation, and 4) excessive livestock access to stream banks.

\section{TMDL Issues}

Listing history: 1996-Yes; 2000, 2002-Did not meet SCD.

Listed causes of impairment: Siltation, Flow alteration, pathogens.

\section{Dewatering Issues}

The lower mile of McElwain Creek is on the dewatered stream list due to irrigation.

\section{Native Species Issues}


WSCT genetic composition: tested 100\% WSCT

\section{Restoration Activities}

\section{Past Restoration}

Some grazing improvements have been completed, including the removal of a streamside feedlot and offstream water development.

\section{Current/Planned Restoration}

Grazing improvements and offstream water are in the development phases.

\section{Monitoring Activities}

\section{Past Monitoring}

FWP inventoried fish populations in 1998 and measured stream temperatures in 20002002.

\section{Ongoing Monitoring}

None

\section{Planned Future Monitoring}

None

\section{SALMON CREEK: Priority - High \\ Description}

Salmon Creek, a small, 1st order outlet stream from Coppers Lake, flows $\sim 2.5$ miles in length through entirely public (National Forest) private agricultural land before joining Dry Creek to form Rock Creek. This small stream received high rankings for restoration priority and total rank, native species, biological and sport fishery values. Salmon Creek has a low potential to improve on water quality and received a low rank for social/financial considerations. Salmon Creek, located in the North Fork bull trout core area, supports very low densities of both juvenile bull trout and fluvial WSCT along with high densities of brook trout. Most of the habitat-related problems were corrected on Salmon Creek through extensive restoration. Current fisheries impairments, located on lower Salmon Creek include instream flow problems related to flood irrigation.

\section{TMDL Issues}

Not listed

\section{Dewatering Issues}

Irrigation occurs but at currently insufficient levels to include Salmon Creek on the dewatered stream list.

\section{Native Species Issues}

Bull trout core area stream

No evidence of WSCT reproduction

\section{$\underline{\text { Restoration Activities }}$}

\section{Past Restoration}

Between 1996 and 2000, a comprehensive fisheries improvement project was completed on Salmon Creek. The project included channel reconstruction, habitat enhancement, 
increased stream flows, changes to streamside grazing, removal of a streamside corral, fish screening on two ditches and the placement of a Denil fish ladder to the outlet structure of Spawn Lake.

\section{Current/Planned Restoration}

Water conservation projects are being discussed.

\section{Monitoring Activities}

\section{Past Monitoring}

FWP conducted fish population surveys in 1994, 1995, and 1999 and tested for whirling disease in 1997.

\section{Ongoing Monitoring}

None

\section{Planned Future Monitoring}

None

\section{SHANLEY CREEK: Priority - High \\ Description}

Shanley Creek, a 2nd order tributary to Cottonwood Creek, flows $\sim 9$ miles through public and private land, including the Bandy Experimental Ranch. Shanley Creek received a high total rank and biological rank and a moderate native species value. Shanley Creek's high total rank is due to a high (multi-species) sport fishery value and potential water quality benefits. Shanley Creek, located in the Cottonwood Creek bull trout core area, historically contained bull trout based on landowner interviews. However, this species was absent from recent FWP surveys. Shanley Creek now contains resident WSCT, brown trout and brook trout. WSCT dominate upper Shanley Creek. Brown trout dominate lower Shanley Creek. Several restoration projects were completed on Shanley Creek including livestock management changes, and screening an irrigation ditch. Current fisheries impairments include degraded riparian vegetation due to excessive livestock access to stream banks.

\section{TMDL Issues}

Not listed

\section{Dewatering Issues}

The lower 1.6 miles of Shanley Creek is on the dewatered stream list due to irrigation, although attempts are made to maintain a minimal flow level.

\section{Native Species Issues}

Bull trout core area stream.

WSCT genetic composition: tested $100 \%$ WSCT

\section{$\underline{\text { Restoration Activities }}$}

\section{Past Restoration}

Three restoration projects were completed on Shanley Creek beginning in 1994. These involved a riparian exclosures near the mouth, the placement of a fish screen on the ditch to Bandy Reservoir and the development of a three pasture riparian grazing system 
between stream mile 0.6 and 1.8 .

\section{Current/Planned Restoration}

None, although grazing plans need to be evaluated and refined.

\section{Monitoring Activities}

\section{Past Monitoring}

FWP inventoried fish populations in 1993 and 1996 and continued to monitor populations in 1997, 2001 and 2003. FWP measured stream temperatures in 1997 and 1999 and tested for whirling disease in 1997.

\section{Ongoing Monitoring}

Periodic fish population monitoring related to restoration action is expected to continue.

\section{Additional Planned Monitoring}

None beyond periodic fish population monitoring. A grazing monitoring plan should be developed.

\section{SPRING CREEK (upper Cottonwood): Priority - High Description}

Spring Creek, a 1st order tributary to upper Cottonwood Creek, flows $\sim 2.5$ miles exclusively through private timber and agricultural lands. Spring Creek scored high in total rank due to high native species value, high (multi-species) sport fishery value, and potential to increase flows to the Blackfoot River. Spring Creek has low potential to improve downstream water quality and ranks low in social and financial considerations. Located in the bull trout core area, Spring Creek supports WSCT and brook trout and bull trout rearing as recently as 1989. Since 1989, Spring Creek has been diverted on a yeararound basis and is now disjunct from Cottonwood Creek. Bull trout have not been detected in more recent sampling. Fisheries impairments in the lower reaches include: 1) irrigation impacts (fish passage, entrainment, and dewatering), 2) channel alterations, and 3) suppressed riparian vegetation.

\section{TMDL Issues}

Not listed

\section{Dewatering Issues}

The lower mile of Spring Creek is on the dewatered stream list due to irrigation.

\section{Native Species Issues}

Bull trout core area stream.

WSCT genetic composition: untested

\section{Restoration Activities}

\section{Past Restoration}

None

Current/Planned Restoration

None

\section{Monitoring Activities}




\section{Past Monitoring}

FWP conducted fish population surveys in 1989 and 1999.

\section{Ongoing Monitoring}

None

Planned Future Monitoring

None

\section{STONEWALL CREEK: Priority - High}

Description

Stonewall Creek is a $1^{\text {st }}$ order tributary stream to Keep Cool Cr, a $3^{\text {rd }}$ order tributary stream to the upper Blackfoot River. Stonewall Creek drains the western slopes of Stonewall Mountain then flows south $\sim 7.65$ miles through a checkerboard of public (National Forest and State) and private lands. Stonewall Creek ranks high on the restoration priority and total ranking list due to a high sport fishery value (multi-species), and moderate potential to improve Blackfoot River water quality by reducing sediment and temperature and increase stream flows. Stonewall Creek supports populations of WSCT, brown trout, and brook trout. Fish densities are low throughout the drainage. Brown and resident brook trout are found in the lower reaches of the stream. Middle reaches support resident WSCT and brook trout and only WSCT were found in the upper reaches. Fisheries impairments include: 1) elevated sediment levels, 2) excessive livestock grazing impacts on riparian vegetation, 3) over-widened stream banks and braided channel, 4) instream flows (dewatering both natural and irrigation induced), 5) extensive placer mining, and 6) a stream ford at the USFS boundary.

\section{TMDL Issues}

Not listed

\section{Dewatering Issues}

The lower two miles of Stonewall Creek is on the dewatered stream list due to irrigation and natural losses.

Native Species Issues

WSCT genetic composition: tested 100\% WSCT

\section{Restoration Activities}

\section{Past Restoration}

None

Current/Planmed Restoration

None

\section{Monitoring Activities}

Past Monitoring

FWP conducted fish population surveys and measured water temperatures in 2004.

\section{Ongoing Monitoring}

None

Planned Future Monitoring 
None

\section{WALES SPRING CREEK: Priority - High}

\section{Description}

Wales Spring Creek, a $1^{\text {st }}$ order spring creek tributary to lower Wales Creek, flows $\sim 0.9$ miles through private ranch land. Wales Spring Creek ranks high on the restoration priority and total ranking list due to its high potential to improve water quality, moderate native species value and multi-species sport fishery value to the Blackfoot River. Wales Spring Creek supports moderate densities of brown trout and very low densities of WSCT. Fish likely coming from Wales Creek, no spawning habitat observed. Fisheries impairments include: 1) slumping stream banks, 2) excessive livestock grazing impacts on riparian vegetation (grasses).

\section{TMDL Issues}

Listed

Dewatering Issues

None

Native Species Issues

No evidence of WSCT reproduction

\section{Restoration Activities}

\section{Past Restoration}

None

Current/Planned Restoration

Wales Spring Creek will be assessed for restoration in 2005.

\section{Monitoring Activities}

\section{Past Monitoring}

FWP inventoried fish populations and measured stream flows in 2003.

\section{Ongoing Monitoring}

None

\section{Planned Future Monitoring}

None

\section{WASSON CREEK: Priority - High \\ Description}

Wasson Creek is a small 1st order tributary to upper Nevada Spring Creek with a length of $\sim 8.4$ miles. The Wasson drainage contains both public (National Forest) land in the upper drainage and private land downstream of mile $\sim 4$. Wasson Creek ranks high on the restoration priority and total ranking list due to a high rank in potential water quality benefits, potential to increase flow in the Blackfoot River, moderate native species values and a moderate rank in social and financial considerations. Wasson Creek supports high densities of WSCT in upper reaches with densities decreasing significantly in lower reaches. Impairments to fisheries, located in the middle and lower reaches, include: 1) 
excessive livestock access to the stream, 2) channel alterations, 3) dewatering, 4) possible fish barriers at diversion points, and 5) a culvert crossing on the National Forest.

TMDL Issues

Not listed

\section{Dewatering Issues}

The lower two miles of Wasson Creek is listed on the dewatered stream list due to irrigation.

\section{Native Species Issues}

WSCT genetic composition: tested $100 \%$ pure

\section{$\underline{\text { Restoration Activities }}$}

\section{Past Restoration}

Past restoration actions involve irrigation diversion upgrades, cattle fords, off stream water developments and riparian pastures.

\section{Current/Planned Restoration}

A comprehensive restoration project for Wasson Creek is currently being developed with private landowners. The project is expected to include: 1) enhancement of instream flows, 2) improvement of riparian grazing and 3) reconstruction of less than a mile of stream.

\section{Monitoring Activities}

\section{Past Monitoring}

FWP inventoried fish population 1991 and re-surveyed established sites in 2000, 2003 and 2004. FWP measured stream temperatures and stream flows in 2000, 2003 and 2004 and tested for whirling disease in 1997. Channel measurements related to instream flow needs and channel reconstruction were collected 2004.

\section{Ongoing Monitoring}

FWP expects to continue to monitor fish populations, flows and water temperatures on an ongoing basis until approximately 2010, if the current restoration project develops as anticipated.

\section{Planned Future Monitoring}

None beyond expected ongoing monitoring. 


\section{MODERATE PRIORITY STREAMS}

\section{BEAR CREEK (rm 12.2): Priority - Moderate \\ Description}

Bear Creek, a small, 2nd order tributary to the lower Blackfoot River, flows $\sim 6$ miles through private land including industrial forest in upper reaches. Bear Creek has received extensive restoration over the last several years. With the exception of undersized culverts in the headwaters, Bear Creek is approaching final restoration phases. Bear Creek ranks moderate on the restoration priority list for total and biological rank and high for native species and multi-species sport fishery value but low in potential water quality benefit due to the completion of many restoration projects in the basin. Bear Creek supports limited bull trout rearing, fluvial WSCT, rainbow trout, brown trout and resident brook trout. Bear Creek is the tributary south of reach 6 of the Blackfoot River thought to provide significant recruitment to the Blackfoot River sport fishery. Fisheries-related impairments involve perceived elevated levels of stream sediment resulting from extensive timber harvest and road drainage. Culverts at two locations appear undersized and should be evaluated for fish passage. In the lower reaches of Bear Creek, the stream is currently in the restoration recovery phases where channel reconstruction and grazing management changes were completed.

\section{TMDL Issues}

Not listed

\section{Dewatering Issues}

None

\section{Native Species Issues}

Bull trout rearing

WSCT genetic composition: untested

\section{Restoration Activities}

\section{Past Restoration}

Beginning in 1995, approximately $6000^{\circ}$ of lower Bear Creek was reconstructed or habitat enhanced where channelization and historical grazing had damaged the channel. The project involved grazing management changes, shrub planting and improved diversions at two locations. In 1996, culverts at two locations were upgraded; however, these culverts do not appear to be meeting fish passage objectives and need to be reevaluated.

\section{Current/Planned Restoration}

Two possible stream crossings are under consideration for upgrades.

\section{Monitoring Activities}

\section{Past Monitoring}


FWP conducted fish population surveys in 1994, 1995, and 1998-2004. Water temperature data was collected in 1998, 2001 and 2002. FWP completed a post reconstruction habitat survey in 1998. FWP tested for whirling disease in bear Creek in 2004 , the results of which are pending.

\section{Ongoing Monitoring}

Fish population monitoring in the restoration project area is nearing completion.

\section{Planned Future Monitoring}

McNeil core sampling is tentatively planned for 2005-06. Periodic project monitoring and fish population survey may continue. Stream sediment delivery should also be evaluated.

\section{BLACKFOOT RIVER (reach 3: Arrastra creek to Nevada Creek): Priority - Moderate}

\section{Description}

This $4^{\text {th }}$ order reach extends 21.1miles from Arrastra Creek (mile 88.8) downstream to Nevada Creek (mile 67.7) through a mix of private ranch and public (National Forest, State and BLM) lands. No tributary streams enter this reach of the Blackfoot River. The channel loses slope and becomes highly sinuous, erosive and prone to the deposition of fine sediment due to the extremely low channel slope. Instream wood and channel complexity decreases in the downstream direction. Water temperature changes are more extreme during summer and winter as compared with the upstream reach (2). The salmonid assemblage includes low densities of brown trout as the dominant fish, followed by very low densities of WSCT and bull trout. This reach ranks high in native species and biological values but moderate with other criteria, resulting in a moderate total rank. Beyond a host of natural limiting factors, human-related fisheries impairments include: 1) irrigation related low flows, 2) entrainment of fish to some ditches, 2) reduced instream complexity, and 3) excessive livestock to riparian areas resulting in suppressed riparian vegetation and stream bank degradation. Whirling disease is also increasing in this reach.

\section{TMDL Issues}

Listed

\section{Dewatering Issues}

The majority of this river reach (17.1 miles) is on dewatered stream list due to irrigation.

\section{Native Species Issues}

Bull trout nodal habitat, proposed critical bull trout habitat

\section{$\underline{\text { Restoration Activities }}$}

\section{Past Restoration}

Streamside corrals were removed at one location.

\section{Current/Planned Restoration}

One fish screen project is being developed. Irrigation canal on this portion of the Blackfoot River will be evaluated for entrainment in 2005. 


\section{Monitoring Activities}

\section{Past Monitoring}

An FWP completed habitat survey and native fish telemetry study was completed in 2003-04. Water temperature monitoring began in the early 1990s. A USGS monitoring station (\#12335100) was recently established and has three years of continuous flow data. Water quality and macro-invertebrates were assessed at one location in 1988-89 (Ingman et al. 1990). A riparian health inventory was conducted in 1999 (Marler and Schmetterling).

\section{Ongoing Monitoring}

FWP collects monitors summer water temperature and whirling disease surveys on an annual basis.

\section{Planned Future Monitoring}

None beyond ongoing monitoring activities.

\section{DRY CREEK: Priority - Moderate}

\section{Description}

Dry Creek is a tributary to Rock Creek in the North Fork of the Blackfoot River drainage. It flows through public (National Forest) land except for the lower-most portion of the stream. Dry Creek ranks moderate on the restoration priority and total rank list and has a high native species value. Dry Creek is considered a non-impaired stream due to recent grazing management changes on private land, which will address the only known fisheries-impairment to this stream. Dry Creek supports bull trout rearing, fluvial WSCT and resident brook trout.

\section{TMDL Issues}

Not listed

\section{Dewatering Issues}

The lower 0.5 miles of lower Dry Creek is on the dewatered stream list due to natural losses.

\section{Native Species Issues}

Bull trout core area stream

Fluvial WSCT spawning stream

WSCT genetic composition: tested $100 \%$ WSCT

\section{$\underline{\text { Restoration Activities }}$}

Past Restoration

Riparian grazing improvements were initiated in 2001.

\section{Current/Planned Restoration}

None

\section{Monitoring Activities}

\section{Past Monitoring}

FWP conducted fish population surveys in 1994 and 2000. The USFS has collected McNeil core sampling over several years. 
Ongoing Monitoring

None

Planned Future Monitoring

None

\section{LITTLE FISH CREEK: Priority - Moderate}

Description

Little Fish Creek is a small $1^{\text {st }}$ order tributary stream to the lower Blackfoot River. Draining the southern slopes of Lost Horse Mountain, it flows 5.8 miles in a northwest direction through a mix of public (State, BLM) and private agricultural and industrial forest (Plum Creek) lands before entering the Blackfoot River at river mile 32.8. Little Fish Creek received a moderate total ranking because of a high ranking in social and financial considerations, a high biological ranking and moderate native species value. Little Fish also has a single-species sport fishery value and potential to increase flows to the Blackfoot. Little Fish Creek supports only WSCT throughout it entire length. Fish densities are low and decrease in the downstream direction. Fisheries impairments include: 1) road crossing (undersized culvert), 2) irrigation impacts (low flow), 3) areas of excessive livestock grazing on riparian vegetation, stream bank degradation, and moderate to high sediment levels, and 4) road drainage.

TMDL Issues

Not listed

Dewatering Issues

Unknown

Native Species Issues

WSCT genetic composition: tested $100 \%$ WSCT

Restoration Activities

Past Restoration

None

Current/Planned Restoration

None

Monitoring Activities

Past Monitoring

FWP inventoried fish populations in 2003.

Ongoing Monitoring

None

Planned Future Monitoring

None

LODGEPOLE CREEK: Priority - Moderate Description 
Lodgepole Creek is the primary tributary to Dunham Creek. It drains Monture Mountain before flowing exclusively through public (National Forest) land. Lodgepole Creek received a moderate rank on the restoration priority and total rank list due to its high native species value, moderate biological priority rank, and lack of any known impairments. Lodgepole Creek supports both WSCT and bull trout in low numbers.

\section{TMDL Issues}

Not listed

\section{Dewatering Issues}

None

\section{Native Species Issues}

Bull trout core area stream, proposed critical bull trout habitat.

WSCT genetic composition: untested

\section{$\underline{\text { Restoration Activities }}$}

\section{Past Restoration}

A bridge was constructed on the Forest Service land to facilitate high flows and address fisheries concerns.

\section{Current/Planned Restoration}

None

\section{Monitoring Activities}

Past Monitoring

FWP conducted fish population surveys in 1996.

\section{Ongoing Monitoring}

None

Planned Future Monitoring

None

\section{NEVADA SPRING CREEK: Priority - Moderate \\ Description}

Nevada Spring Creek, a $2^{\text {nd }}$-order spring creek tributary to lower Nevada Creek, flows $\sim 3.2$ miles in length exclusively though private ranch land. Nevada Spring Creek ranks moderate on the restoration priority and total rank list due to moderate native species values and high biological priority values. Nevada Spring Creek has potential to increase flow in the Blackfoot and the high potential to improve downstream water quality to lower Nevada Creek and possibly the Blackfoot River. Nevada Spring Creek supports very low densities of fluvial WSCT and brown trout in the upper reaches and very low densities of WSCT, brown trout and bull trout in the lower reaches. Before 2001 fisheries impairments, located over the length of the stream include: 1) irrigation impacts (dewatering and fish passage), 2) channel alterations, 3) lacks instream complexity, 4) degraded riparian vegetation resulting from excessive livestock access to stream banks. Nevada Spring Creek tested negative for whirling disease in 2002. 


\title{
TMDL Issues
}

Listing history: 1996-unknown; 2000-Yes; 2002-Yes; 2004-Yes.

Listed causes of impairment: Habitat alterations, siltation

\section{Dewatering Issues}

Dewatering issues were addressed as part of the 2003 restoration project.

\author{
Native Species Issues \\ Limited bull trout rearing \\ WSCT genetic composition: untested
}

\section{$\underline{\text { Restoration Activities }}$}

\section{Past Restoration}

Since 2001, Nevada Spring Creek has been the focus of a concerted restoration effort over its entire length, which included channel reconstruction, instream flow enhancement and riparian grazing changes. The entire Nevada Spring Creek has been subject to an extensive restoration project, involving complete reconstruction and livestock management measures.

\section{Current/Planned Restoration}

Current planned work involves completion of localized floodplain work. This involves importing sod mats to areas where the floodplain is to be elevated to better maintain channel cross-section. Shrub planned for the final phases of the project.

\section{Monitoring Activities}

\section{Past Monitoring}

FWP inventoried fish populations in 1990 and resurveyed monitoring sites in 1991-02, 1994, and in 2000-2004. FWP sampled dissolved oxygen and water quality at two sites in 1989. FWP measured stream temperatures in 2000 through 2004, and stream flows in 2000, 2002 and 2004. FWP completed a baseline habitat assessment in 1990 and postproject survey in 2003-04. FWP tested for whirling disease in 1997 and 2002-2004.

\section{Ongoing Monitoring}

Fish population and water temperature measurements are expected to continue for the next 3-5 years.

\section{Planned Future Monitoring}

None beyond ongoing monitoring

\section{YOURNAME CREEK: Priority - Moderate \\ Description}

Yourname Creek, a 2nd order tributary to the middle Blackfoot River, originates near Elevation Mountain and flows $\sim 9$ miles through both public (BLM) and private land. Public land is found only in the upper 1.4 miles of stream. Yourname Creek ranks moderate for restoration priority and total rank due to a 1) moderate native species value, 2) single-species sport fishery value to the Blackfoot River, 3) potential to improve downstream water quality to the Blackfoot River, and 3) potential to increase flow to the Blackfoot River. Yourname Creeks ranks low for social and financial considerations. Yourname Creek supports a genetically pure population of fluvial WSCT with densities 
increasing substantially in the upstream direction. Fisheries impairments include: 1) irrigation impacts (dewatering and entrainment), 2) lack of instream complexity, and 3) degraded stream banks resulting form excessive livestock access to riparian areas.

\section{TMDL Issues}

Listing history: 1996-Yes; 2000-Yes; 2002-Yes; 2004-Yes.

Listed causes of impairment: Flow and habitat alterations, riparian degradation, siltation, and phosphorus.

\section{Dewatering Issues}

The lower mile of Yourname Creek is on the dewatered stream list due to irrigation.

\section{Native Species Issues}

WSCT genetic composition: tested $100 \%$ pure

\section{Restoration Activities}

\section{Past Restoration}

None

Current/Planned Restoration

None

\section{Monitoring Activities}

Past Monitoring

FWP inventoried fish populations in 1992 and 2000, measured stream temperatures in 2000-2004 and stream flows in 2000.

\section{Ongoing Monitoring}

None

Planned Future Monitoring

None

\section{EAST TWIN CREEK: Priority - Moderate \\ Description}

East Twin Creek is a small 2nd order tributary to the lower Blackfoot River. It flows $\sim 5$ miles through private land, except for a small parcel of public land in the headwaters. East Twin Creek ranks moderate on the restoration priority list, due to low potential for improving downstream water quality and increasing flows to the Blackfoot River, and a high ranking in native species value as it supports bull trout rearing and fluvial WSCT. East Twin Creek provides a high (multi-species) sport fishery value to the Blackfoot River by supporting a diverse fish assemblage of fluvial WSCT, bull trout, rainbow trout, brown trout, and resident brook trout. In general, densities are low for all species in the lower to middle reaches. The only known problem for East Twin Creek is an undersized culvert, which contributes to localized channel instability.

TMDL Issues

Not listed 
Dewatering Issues

None

Native Species Issues

$\underline{\text { Restoration Activities }}$

Past Restoration

An undersized culvert was replaced in the mid-1990s.

Current/Planned Restoration

None

$\underline{\text { Monitoring Activities }}$

Past Monitoring

FWP conducted fish population surveys in 1996, 1998 and 2000, and measure stream temperature in 1998, 1999 and 2001.

Ongoing Monitoring

None

Planned Future Monitoring

None

\section{JOHNSON CREEK: Priority - Moderate}

Description

Johnson Creek is a 2nd order tributary to the lower Blackfoot River that drains public (National Forest) and private land. Johnson Creek received a moderate rank in the total and restoration priority rank list, and a high native species rank. Restoration work (fish passage near the mouth) was completed in 1997. No additional impairments on this stream are known. Johnson Creek is a small, cold stream that supports several fish species including bull trout, WSCT, rainbow trout and brown trout in low numbers.

TMDL Issues

Not listed

Dewatering Issues

None

Native Species Issues

Bull trout rearing stream, concentrates bull trout at the mouth

WSCT genetic composition: tested $100 \%$ WSCT

\section{$\underline{\text { Restoration Activities }}$}

\section{Past Restoration}

A stream crossing was improved in the late 1997 to improve fish passage.

Current/Planned Restoration

None

\section{$\underline{\text { Monitoring Activities }}$}




\section{Past Monitoring}

FWP inventoried fish population 1997, measured stream temperatures in 1999 and stream flow in 2000 .

\section{Ongoing Monitoring}

None

\section{Planned Future Monitoring}

None

\section{KEEP COOL CREEK: Priority - Moderate \\ Description}

Keep Cool Creek, a 3rd order tributary to the upper Blackfoot River, drains Stonewall Mountain and the Keep Cool Lakes. Keep Cool Creek flows $\sim 12$ miles through public (National Forest) land before entering private land near mile $\sim 6$. Keep Cool Creek ranks moderate in the total ranking and restoration priority list. This rank is due to a moderate native species rank, high (multi-species) sport fishery value to the Blackfoot River and high potential to improve water quality in the Blackfoot River by reducing sediment and temperature. Keep Cool Creek supports populations of fluvial WSCT and brown trout and limited bull trout use. Brown trout are found in low numbers in the lower reaches of the stream. Fisheries impairments include 1) mining impacts, 2) dewatering and 3) excessive access by livestock to the stream banks in the middle reaches.

\section{TMDL Issues}

Not listed

\section{Dewatering Issues}

Two miles of upper Keep Cool Creek are on the dewatered stream list due to irrigation.

\section{Native Species Issues}

Receives fluvial bull trout use (non spawning)

WSCT genetic composition: tested $100 \%$ WSCT

\section{Restoration Activities}

\section{Past Restoration}

The middle portion of Keep Cool Creek is currently under more sensitive grazing management. The USFS has upsized culverts.

\section{Current/Planned Restoration}

The USFS is planning additional road crossing improvements on the Sucker/Copper road.

\section{Monitoring Activities}

\section{Past Monitoring}

FWP inventoried fish population and measured stream temperatures and stream flows in Keep Cool Creek in 2004.

Ongoing Monitoring

None

\section{Planned Future Monitoring}

None 


\section{PEARSON CREEK: Priority - Moderate \\ Description}

Pearson Creek, a small 2nd order Garnet Mountain tributary to Chamberlain Creek, flows $\sim 9$ miles through mostly private (Plum Creek) land and a small section of public (BLM) land in the upper reaches. Pearson Creek ranks moderate on the restoration priority and total rank list due to a moderate native species rank, low (single-species) sport fishery value and high potential for improving downstream water quality. Pearson Creek supports fluvial WSCT in the lower drainage. Pearson Creek has been the site of and extensive restoration program, which corrected the majority of identified problems. Current fisheries impairments located in lower Pearson Creek include: 1) lack of instream complexity, 2) degraded riparian vegetation, and 3) road drainage problems.

\section{TMDL Issues}

Not listed

\section{Dewatering Issues}

Two miles of lower Pearson Creek are listed on the dewatered stream list due to natural losses and past irrigation practices. This reach of stream has been under a water lease since 1996 and currently is not dewatered except in drought years.

\section{Native Species Issues}

WSCT genetic composition: tested $98 \%$ WSCT

\section{$\underline{\text { Restoration Activities }}$}

\section{Past Restoration}

Reconstruction of three segments of channel totaling $\sim 4,000$ feet of stream, water lease for all flows from the watershed, habitat restoration including shrub planting, wood placement and grazing management changes began in 1996.

\section{Current/Planned Restoration}

Additional grazing management changes are ongoing.

\section{Monitoring Activities}

\section{Past Monitoring}

FWP conducted fish population surveys in 1994, 1995, 1997, 1999, 2001, and 20022004.

\section{Ongoing Monitoring}

Annual water lease and fish population monitoring are expected to continue.

\section{Planned Future Monitoring}

Future grazing monitoring is needed.

\section{SAUERKRAUT CREEK: Priority - Moderate \\ Description}

Sauerkraut Creek, a 1st order tributary to the upper Blackfoot River, flows $\sim 7$ miles through public (National Forest) land in the headwaters and private land downstream of mile $\sim 3$. Sauerkraut Creek received a moderate rank on the restoration priority and total 
rank list due high native species values, high (multi-species) sport fishery value to the Blackfoot River, and moderate potential to improve water quality in the Blackfoot River. Sauerkraut Creek received a low rank for social and financial considerations. Sauerkraut Creek supports limited bull trout rearing, fluvial genetically pure WSCT, brown trout and brook trout. We found bull trout and brown trout in lower Sauerkraut Creek, whereas WSCT and brook trout are found throughout the drainage. Brook trout densities decrease in the upstream direction. Fisheries impairments, located in the middle reaches, include: 1) undersized culverts, 2) road sediment delivery to the stream, 3) channelization and a lack of instream complexity due to placer and gravel mining activity, and 3) stream bank damage in localized area excessive livestock access to riparian areas.

TMDL Issues

Not listed

Dewatering Issues

Unknown

Native Species Issues

Limited bull trout rearing

Fluvial WSCT spawning stream

WSCT genetic composition: tested $100 \%$ WSCT

Restoration Activities

Past Restoration

None

Current/Planned Restoration

None

Monitoring Activities

Past Monitoring

FWP inventoried fish population in 1999 and measured stream temperatures in 2002 and 2003. Telemetry identified this stream as a fluvial WSCT spawning stream.

\section{Ongoing Monitoring}

None

Planned Future Monitoring

None

\section{WALES CREEK: Priority - Moderate \\ Description}

Wales Creek, a 2nd order tributary to the middle Blackfoot River, flows $\sim 9$ miles through both public (BLM) in headwater areas and private ranch land downstream of mile $\sim 4$.

Wales Creek ranks moderate in total rank and restoration priority due to a 1) moderate native species value, 2) high (multi-species) sport fishery value to the Blackfoot River, 3 ) potential to increase flow in the Blackfoot, and 4) potential to improve water quality in the Blackfoot River. Wales Creek ranks low for social and financial considerations. A large instream reservoir limits the ability to address the entire Wales Creek system. 
Species composition is comprised of fluvial WSCT (below reservoir) and resident WSCT (above reservoir). The lower reaches also contain low brown trout densities. Above the reservoir, (mile 2.0), Wales Creek supports genetically pure WSCT. Fisheries impairments above and below the reservoir include stream bank damage resulting from excessive livestock access to riparian areas. Severe dewatering occurs below the reservoir

\section{TMDL Issues}

Listing history: 1996-Yes; 2000, 2002-Did not meet SCD; 2004-Yes.

Listed causes of impairment: Flow and habitat alterations, siltation

\section{Dewatering Issues}

The lower 1.9 miles of Wales Creek is on the dewatered stream list due to irrigation.

Native Species Issues

WSCT genetic composition: tested $100 \%$ above the reservoir

Isolet WSCT population above the reservoir

Introgression present below the reservoir

\section{Restoration Activities}

\section{Past Restoration}

Riparian pasture was developed upstream of the reservoir in 2004 in order to reduce grazing pressure on the riparian area.

\section{Current/Planned Restoration}

None

\section{Monitoring Activities \\ Past Monitoring}

FWP conducted fish population surveys in 1989, 2000 and 2003, measured stream temperatures in 2001, 2003 and 2004 and stream flows in 1989, 2000 and 2003. A telemetry study in 2002-03 identified Wales Creek as an important WSCT spawning stream. FWP tested for whirling disease in 2004.

\section{Ongoing Monitoring}

None

\section{Planned Future Monitoring}

None

\section{WEST TWIN CREEK: Priority - Moderate Description}

East Twin Creek is a small 3rd order tributary to the lower Blackfoot River, which originates from the slopes of Wisherd Ridge and Sheep Mountain. It flows south through public (National Forest) and private land. West Twin Creek is a past project stream in which the only known impairment was addressed with the completion of a fish passage project at Highway 200. West Twin Creek received a moderate rank on the restoration priority and total rank list and a high native species value. West Twin Creek supports a 
high value sport fishery with a mixed species composition of WSCT, rainbow trout, brown trout, and brook trout in low numbers

\section{TMDL Issues}

Not listed

\section{Dewatering Issues}

None

\section{Native Species Issues}

WSCT genetic composition: untested

\section{Restoration Activities}

Past Restoration

FWP assisted with a fish passage project near the mouth in the early 1990s

\section{Current/Planned Restoration}

None

\section{Monitoring Activities}

Past Monitoring

FWP conducted fish population surveys in 1996, measured stream flows in 2000 , measured stream temperatures in 1998, 1999 and 2001 and tested for whirling disease in 2004.

\section{Ongoing Monitoring}

None

\section{Planned Future Monitoring}

None

\section{ARRASTRA CREEK: Priority - Moderate Description}

Arrastra Creek, a large $2^{\text {nd }}$ order middle Blackfoot River tributary, flows 13 miles through public (National Forest) and private land. The lower half of the stream is private. Arrastra Creek ranks moderate in total ranking on the restoration priority list. Supporting bull trout spawning and rearing and genetically pure fluvial WSCT, it ranks high in native species value. Arrastra Creek provides a high (multi-species) sport fishery value to the Blackfoot River and ranks high on the biological priority list. A telemetry study conducted in the Blackfoot River watershed in 2002-03 identified Arrastra Creek as a primary fluvial WSCT spawning tributary. Arrastra Creek also supports populations of brown trout and resident brook trout. Fish densities are low for all species in lower reaches, but increase to moderate levels in middle reaches. Upper Arrastra Creek supports a native fish assemblage with both WSCT and bull trout. Fisheries impairments include a complete fish passage barrier in upper Arrastra Creek and a partial barrier in lower Arrastra Creek. We have identified no substantive water quality problems for Arrastra Creek, sediment-related issues are likely due to extensive timber harvest and road construction in the watershed. Fisheries impairments include 1) riparian timber harvest and habitat simplification and suspected road drainage, 2) perched culverts 
limiting upstream fish passage in the headwater and near the mouth, and 3) localized recreational impacts to stream banks. A low level of whirling disease was detected in Arrastra Creek in 2003.

\section{TMDL Issues}

Listing History: 1996-Yes; 2000-Yes; 2002-Yes; 2004-Yes.

Listed causes of impairment: Flow alteration, siltation and other habitat alterations.

\section{Dewatering Issues}

Arrastra Creek is on dewatered stream list between mile 2.0 and 4.5 due to natural dewatering.

\section{Native Species Issues}

Non-core area bull trout spawning stream.

Fluvial WSCT spawning stream

WSCT genetic composition: tested 100\% WSCT

\section{Restoration Activities}

\section{Past Restoration}

None

\section{Current/Planned Restoration}

The removal of perched culverts at stream mile 3.5 is planned for fall of 2005. Velocities at high flows through these culverts have been measured at $8 \mathrm{ft} / \mathrm{sec}$, sufficient to prevent seasonal upstream movements

\section{Monitoring Activities}

\section{Past Monitoring Activities}

FWP inventoried fish population data in 1989 and resurveyed sites in 1996, 1999 and 2004, measured stream temperatures in 1999, 2001, 2002, 2003 and stream flows in 1989 and 2000. FWP began testing for whirling disease in 2003 and 2004. An ambient water quality survey was completed in 1989 (Ingman et al. 1990).

\section{Ongoing Monitoring}

Periodic samplings of fish populations and whirling disease are expected to continue.

\section{Planned Future Monitoring}

McNeil core samples are planned for 2005. An evaluation of roads and road drainage from a stream - sediment delivery perspective should also be conducted in the watershed.

\section{BLACKFOOT RIVER (Reach 5: North Fork to Clearwater River): Priority - Moderate \\ Description}

This $5^{\text {th }}$ order reach of the Blackfoot River extends 19.3 miles from the North Fork (mile 54) downstream to the Clearwater River (mile 34.7). It flows through a mix of private agricultural and industrial forest (Plum Creek) lands and public (BLM, State) lands. Several tributaries enter this reach (North Fork Blackfoot River, Warren Creek, Monture Creek, Chamberlain Creek, Cottonwood Creek, and Bear Creek). With the exception of Bear Creek, these streams and many of their tributaries have been the focus of restoration 
actions. The two largest tributaries entering this reach, Monture Creek and the North Fork, are critical bull trout spawning streams. To varying degrees, these streams also support and recruit WSCT, rainbow and brown trout to the Blackfoot River. This reach ranked moderate in total ranking as a result of high native species value, a lack of sport fishery value due to the absence of mainstem spawning, and a low potential in downstream water quality benefits. In this reach, rainbow trout become the dominant mainstem salmonid followed by brown trout, WSCT and bull trout. Densities of all species are below potential due to drought, whirling disease and tributary impairments. Most of the mainstem impairments are localized and include channel alterations, past livestock grazing, recreation impacts to banks. Whirling disease has escalated to high levels in this reach. 


\section{TMDL Issues}

Listed

\section{Dewatering Issues}

Although this river reach is subject to upstream dewatering, it is not on the dewatered stream list due to generally sufficient flows except during drought conditions.

\section{Native Species Issues}

Bull trout nodal habitat; proposed critical bull trout habitat, bull trout recovery/recreational conflict area

\section{Restoration Activities}

\section{Past Restoration}

Riparian grazing management changes have occurred in many areas of this reach

\section{Current/Planned Restoration}

None planned

\section{Monitoring Activities}

\section{Past Monitoring}

FWP established the Scotty Brown Bridge fish population survey section in 1982. Fish population and water temperature surveys began in the 1980s. FWP tested for whirling disease testing from 1997 through 2004. DEQ assessed water quality and macro- at four locations in 1988-89 (Ingman et al. 1990).

\section{Ongoing Monitoring}

DNRC monitors flows using aquarods during drought years upstream of the Clearwater River junction. FWP monitors summer water temperature and whirling disease on an annual basis.

\section{Planned Future Monitoring}

None beyond ongoing monitoring.

\section{CLEARWATER RIVER: Priority - Moderate \\ Description}

Clearwater River is a major $4^{\text {th }}$ order tributary stream to the middle Blackfoot River. The effluence of Clearwater Lake, it flows $\sim 45.8$ miles through seven lakes (Clearwater chain-o-lakes) and a checkerboard of private, industrial forest (Plum Creek) and public (National Forest and State) lands to its confluence with the Blackfoot River at mile 34.7. The Clearwater River ranks moderately in total ranking on the restoration priority list. This ranking is due in part to low rankings for its potential to improve downstream water quality and social and financial considerations. It also ranked moderate for native species priority, but ranked high in multi-species sport fishery value to the Blackfoot River. Because of the lack of data, only the lower 3.5miles of the Clearwater River is currently the focus of restoration efforts at this time. The Clearwater River supports a multi-species fishery. Data collected in a 2003 fish trap study show salmonid species present include WSCT, rainbow trout, brown trout, and mountain white fish. Bull trout have also been 
observed in the system. In addition, various species of forge fish (longnose dace and redside shiners) are present. The Clearwater chain-of-lakes and river are also a major source of northern pike to the Blackfoot River. Fisheries impairments include irrigation impacts.

\section{TMDL Issues}

Listed

\section{Dewatering Issues}

The lower 3.5 miles of the Clearwater River is on the dewatered stream list due to irrigation.

\section{Native Species Issues}

Fluvial WSCT migration corridor

\section{Restoration Activities}

\section{Past Restoration}

None

\section{Current/Planned Restoration}

An instream flow project was completed in 2004 for the lower 3.5 miles of stream. This project is intended to increase instream flows during drought years. A fish screen is also planned for the canal in 2005.

\section{Monitoring Activities}

\section{Past Monitoring}

FWP conducted juvenile fish population surveys in 1989. FWP conducted electrofishing and ditch trapping in the Clearwater ditch in 2001, 2003 and 2004 to determine number and species entrained. FWP measured water temperatures in 1998 and 2000-2004 and stream flows in 1989, 2000 and 2004. FWP tested for whirling disease in 1997 and 2004. An ambient water quality survey was completed in 1989 (Ingman et al. 1990).

\section{Ongoing Monitoring}

Periodic fish population and water temperature monitoring

\section{Planned Future Monitoring}

In addition to ongoing periodic monitoring, flows will be monitored in the Clearwater canal during low flows years as part of an emergency drought plan.

\section{DOUGLAS CREEK: Priority - Moderate}

\section{Description}

Douglas Creek, a major 3rd order tributary to lower Nevada Creek, flows $\sim 22$ miles through public (BLM) and private ranch land. Most of the drainage, the lower $\sim 18$ miles, is private agricultural land. Douglas Creek ranked high for potential water quality benefits and increases stream flows to the Blackfoot River, but low in native species value and lacks a sport fishery value, which contributed to Douglas Creek's moderate restoration and total priority rank. The upper reaches support pure resident WSCT in moderate densities. Lower and middle Douglas Creek supports low numbers of native non-game fish species. Fisheries impairments, located throughout the drainage, include 1) lack of complex fish habitat (instream wood), 2) livestock induced stream bank 
degradation and riparian vegetation suppression, 3) elevated sediment and elevated nutrient levels and elevated water temperatures, 4) channel degradation related to instability and to road construction, and 5) reduced instream flows from irrigation.

\section{TMDL Issues}

Listing history: 1996-Unknown; 2000-Yes; 2002-Yes; 2004-Yes.

Listed causes of impairments: Siltation, habitat and flow alterations, thermal modification, nutrients, salinity, TDS and chloride.

\section{Dewatering Issues}

The lower 14 miles of Douglas Creek is dewatered due to irrigation.

\section{Native Species Issues}

Isolet WSCT population in headwaters of mainstem

WSCT genetic composition: tested 100\% WSCT

\section{$\underline{\text { Restoration Activities }}$}

\section{Past Restoration}

Fish ladders were constructed around two instream reservoirs in the headwaters in order to include population size for disjunct WSCT in the headwaters.

\section{Current/Planned Restoration}

None

\section{Monitoring Activities}

\section{Past Monitoring}

FWP conducted fish population surveys in 1994, 1997 and 2000, and measured water temperatures in 1998 and 2000 and stream flows in 2000.

\section{Ongoing Monitoring}

None

\section{Planned Future Monitoring}

None

\section{FISH CREEK: Priority - Moderate \\ Description}

Fish Creek, a 1st order tributary to the lower Blackfoot River, flows $\sim 5$ miles through mostly private timber land with a small portion of public (State) land in middle reaches. Fish Creek ranks moderate on the restoration priority list due to a moderate native species value, single species sport fishery value to the Blackfoot River, and potential to increase stream flows to the Blackfoot River. We identified no potential water quality improvement benefits on Fish Creek. Fish Creek supports fluvial WSCT with densities that increase in the upstream direction. Fisheries impairment in the lower $\sim 3$ miles include: 1) dewatering, 2) channel alteration (instream pond), and 3) an undersized culvert creating possible fish barriers.

\section{TMDL Issues}

Not listed 


\section{Dewatering Issues}

The lower 0.3 miles of Fish Creek is on the dewatered due to irrigation.

Native Species Issues

WSCT genetic composition: tested $98 \%$ WSCT

Restoration Activities

Past Restoration

None

Current/Planned Restoration

None

Monitoring Activities

Past Monitoring

FWP inventoried fish populations in 2001.

Ongoing Monitoring

None

Planned Future Monitoring

None

\section{LINCOLN SPRING CREEK: Priority - Moderate}

Description

Lincoln Spring Creek, a large 1st order spring creek flowing through the town of Lincoln, flows $\sim 5$ miles exclusively through private (residential) ownership. Lincoln Spring Creek ranked moderate on the restoration priority and total rank list. This rank is due to a moderate native species value, high (multi-species) sport fishery value to the Blackfoot River, potential to increase flow in the Blackfoot River, and low rank for social and financial considerations. The feasibility to address the entire stream is also questionable. Lincoln Spring Creek currently supports brown trout and brook trout in low densities and receives limited use by fluvial WSCT, but no reproduction. Fisheries impairments include: 1) poor road crossings, 2) lack of instream complexity, 3) degraded riparian vegetation, and 4) residential development.

\section{TMDL Issues}

Not listed

Dewatering Issues

Unknown

Native Species Issues

Historical bull trout use likely

No evidence of WSCT reproduction

Restoration Activities

Past Restoration 
None

\section{Current/Planned Restoration}

None

\section{Monitoring Activities}

\section{Past Monitoring}

FWP inventoried fish populations in 1995 and measured stream temperatures in 2004.

FWP tested for whirling disease in 1997 and 2004.

\section{Ongoing Monitoring}

None

\section{Additional Planned Monitoring}

None

\section{JACOBSEN SPRING CREEK: Priority - Moderate \\ Description}

Jacobsen Spring Creek is a small 1st order spring creek tributary to the North Fork Blackfoot River, a major tributary and bull trout core stream in the Blackfoot River watershed. Jacobsen Spring Creek originates on and flows $\sim 1.6$ miles exclusively through private ranch land. It ranks moderately in total ranking and restoration priority, primarily because of its multi-species sport fishery value, high potential to improve downstream water quality, and high social and financial considerations. Jacobsen Spring Creek supports low densities of brown and moderate numbers of resident brook trout throughout it length. Very low densities of rainbow trout are also present in its lower and middle reaches. Rainbow spawning activity has also been observed in its middle reaches. Fisheries impairments include: 1) areas of livestock-induced stream channel degradation, 2) lacks complex fish habitat (instream wood), 3) livestock-induced riparian vegetation degradation and suppression.

\section{TMDL Issues}

Not listed

\section{Dewatering Issues}

This stream is being evaluated for dewatering.

\section{Native Species Issues}

Bull trout core area stream

No evidence of WSCT reproduction

\section{$\underline{\text { Restoration Activities }}$}

\section{Past Restoration}

None

\section{Current/Planned Restoration}

The lower mile of Jacobsen Spring Creek is being considered for reconstruction and grazing management changes.

\section{$\underline{\text { Monitoring Activities }}$}




\section{Past Monitoring}

FWP and USFWS conducted fish population surveys, monitored flows and collected temperature data in 2004. Geomorphic data (pebble counts, cross-section data) was also collected. The stream was tested for whirling disease in 2004.

\section{Ongoing Monitoring}

Stream flow measurements are ongoing.

\section{Planned Future Monitoring}

Additional monitoring will be considered as restoration plans are developed.

\section{NEVADA CREEK (upper): Priority - Moderate Description}

Upper Nevada Creek, a large 3rd order stream, drains the northern slopes of Nevada Mountain on the continental divide. It flows $\sim 18.8$ miles through a combination of public (National Forest) and private agricultural lands before emptying into Nevada Creek Reservoir at mile 33.7. Upper Nevada Creek received a moderate total rank on the restoration priority list. This rank is due to a high native species value, high potential to improve downstream water quality and moderate social and financial considerations. It lacks sport fishery value to the Blackfoot River. Upper Nevada Creek supports populations of WSCT, rainbow trout, and brook trout. The USFS reports bull trout in upper reaches of Nevada Creek in very low numbers. Low densities of resident WSCT also inhabit the upper reaches of Nevada Creek on National Forest, but numbers decrease in the downstream direction. Rainbow trout and brook trout in low densities are found on private agriculture land upstream of Nevada Reservoir. Many additional tributaries not included in this report that have been sampled by the USFS. These streams variously contain WSCT and brook trout, some of which have impairments identified by the USFS. Fisheries impairments on the mainstem of upper Nevada Creek include: 1) irrigation impacts (low flow), 2) channel alterations and instability, 3) lacks complexity (lacks instream wood), 4) excessive livestock grazing impacts on riparian vegetation and stream bank degradation, 5) low instream flows due to irrigation, 6) historic mining, and) undersized culverts and road sediment delivery to the stream.

\section{TMDL Issues}

Listing history: 1996-Yes; 2000-Yes; 2002-Yes; 2004-Yes.

Listed causes of impairments: Flow and habitat alteration, nutrients, siltation, thermal modification, suspended solids, metals, and nitrogen.

\section{Dewatering Issues}

Six miles of Nevada Creek upstream of the reservoir (stream mile 34-40) is on the dewatered stream list due to irrigation-induced low flows.

\section{Native Species Issues}

WSCT genetic composition: tested $91 \%$ WSCT

\section{$\underline{\text { Restoration Activities }}$}

\section{Past Restoration}


The North Powell Conservation District and NRCS has been involved in attempting to correct non-point runoff problems on private agricultural areas.

\section{Current/Planned Restoration}

None

\section{Monitoring Activities}

Past Monitoring

FWP inventoried fish population in 1957, 1996 and 2001 and measured stream temperatures in 2000 and 2001. A USGS gauging station monitors stream flows upstream of Nevada Reservoir.

Ongoing Monitoring

USGS flow monitoring

Planned Future Monitoring

None beyond ongoing flow monitoring.

\section{SUCKER CREEK: Priority - Moderate}

\section{Description}

Sucker Creek, a $1^{\text {st }}$ order tributary to Keep Cool Creek, drains the southeastern slopes of Stonewall Mountain. It flows south then southwest $\sim 6.0$ miles through a checkerboard of public (National Forest and State) lands and private ranch lands. Sucker Creek received a moderate rank on the restoration priority and total rank list. This moderate rank is the result of its high potential to improve water quality for the Blackfoot River, but lack of sport fishery value. Sucker Creek supports very low densities of WSCT and brook trout in its lower reaches. Fisheries impairments include: 1) irrigation dewatering, 3) elevated sediment levels, 3) excessive livestock grazing impacts to stream banks and riparian vegetation, 4) lack of instream complexity, and 5) an undersized culvert.

\section{TMDL Issues}

Not listed

\section{Dewatering Issues}

The lower mile of Sucker Creek is on the dewatered stream list due to irrigation and has a seasonally intermittent reach on the National Forest.

\section{Native Species Issues}

WSCT genetic composition: untested

\section{Restoration Activities}

\section{Past Restoration}

None

Current/Planned Restoration

None

\section{Monitoring Activities}

Past Monitoring

FWP surveyed fish populations and measured stream temperatures in 2004. 


\section{Ongoing Monitoring}

None

Planned Future Monitoring

None

\section{UNION CREEK: Priority - Moderate}

\section{Description}

Union Creek, a primary 3rd order tributary to the lower Blackfoot River, flows $\sim 18$ miles through both public (BLM) and mainly private ranch land. The lower $\sim 15$ miles of this stream flows through private land. Union Creek ranks moderate on the restoration priority and total rank list. The moderate ranking results from a low native species rank, absence of sport fishery to the Blackfoot River, low rank for social and financial considerations, but high potential to improve water quality and increase flows to the Blackfoot River. Union Creek contains both brook trout and WSCT. Brook trout are present in very low densities in the middle reaches. Resident WSCT were sampled in low numbers in the middle and upper reaches. Fisheries impairments, located in the middle and lower reaches include: 1) poor road crossings (undersized culvert), 2) irrigation impacts (low instream flows), 3) lack of instream complexity, and 4) degraded riparian vegetation resulting from excessive livestock access to stream banks. Lower portions of Union Creek are also undergoing channel incision.

\section{TMDL Issues}

\section{Listed}

\section{Dewatering Issues}

The lower 7.0 miles is on the dewatered stream list due to irrigation.

Native Species Issues

WSCT genetic composition: tested $92 \%$ WSCT

\section{Restoration Activities}

Past Restoration

None

Current/Planned Restoration

None

\section{Monitoring Activities}

Past Monitoring

FWP inventoried fish population in 1989 and re-surveyed sites in 2000 , measured water temperature in 2001 and 2002, measured stream flows in 1989 and 2000 and tested for whirling disease in 2004. An ambient water quality survey was completed in 1989 (Ingman et al. 1990).

Ongoing Monitoring

None

Planned Future Monitoring

None 


\section{WILLOW CREEK (upper): Priority - Moderate \\ Description}

Willow Creek above Lincoln, a 2nd order tributary to the upper Blackfoot River, flows $\sim 8$ miles through public (National Forest) in headwaters and private land downstream of mile $\sim 6$. Willow Creek ranked moderate for total rank and restoration priority due to high potential to improve water quality for the Blackfoot River and single-species sport fishery value to the Blackfoot River. Willow Creek ranks low in native species value and supports low densities of resident WSCT and brook trout. Headwater tributaries on the National Forest also contain WSCT. Fisheries impairments, located in the lower reach include localized stream bank degradation resulting from excessive livestock access to riparian areas.

TMDL Issues

Not listed

Dewatering Issues

The middle reach is seasonally intermittent although the extent is unknown.

Native Species Issues

Fluvial WSCT spawning stream

WSCT genetic composition: tested $100 \%$ pure

\section{Restoration Activities}

Past Restoration

None

Current/Planned Restoration

None

\section{Monitoring Activities}

Past Monitoring

FWP inventoried fish population in 1999 and measured stream temperatures in 2003. A telemetry study conducted by FWP identified upper Willow Creek as an important WSCT spawning tributary. FWP tested for whirling disease in 2004. An ambient water quality survey was completed in 1989 (Ingman et al. 1990).

\section{Ongoing Monitoring}

None

\section{Planned Future Monitoring}

None

\section{WILSON CREEK: Priority - Moderate \\ Description}

Wilson Creek, a 1st order tributary to Lincoln slough (Nevada Creek), flows $\sim 6$ miles first through public (National Forest) and private ranch downstream of mile $\sim 3$. Wilson Creek ranks moderate on the restoration priority and total rank list due to a high potential to improve downstream water quality and potential to increase flows to the Blackfoot, 
low native species value, lack of sport fishery value to the Blackfoot River and low rank for social and financial considerations. Wilson Creek supports a disjunct population of resident WSCT at very low densities. Fisheries impairments in the middle to lower reaches include: 1) placer mining in the headwaters, 2) poor road crossings, 3) irrigation impacts (fish entrainment, low flows), and 4) lack of connectivity to Nevada Creek

\section{TMDL Issues}

Not listed

\section{Dewatering Issues}

The lower 0.8 miles of stream is on the dewatered stream list due to irrigation.

Native Species Issues

Isolet WSCT population

WSCT genetic composition: tested $100 \%$ pure

\section{Restoration Activities}

Past Restoration

None

Current/Planned Restoration

None

\section{Monitoring Activities}

\section{Past Monitoring}

FWP inventoried fish population, measured stream temperatures and stream flows in 2000.

\section{Ongoing Monitoring}

None

\section{Planned Future Monitoring}

None

\section{CHAMBERLAIN CREEK, East Fork: Priority - Moderate \\ Description}

The East Fork of Chamberlain Creek, a small, 1st order tributary to Chamberlain Creek, flows $\sim 3.5$ miles entirely through private (Plum Creek) lands. The East Fork is a past project stream. Past projects include correcting road drainage and replacing a culvert near the mouth. The East Fork ranks moderate on the restoration priority list, biological priority list and native species priority list. These moderate rankings results from single species sport fishery status, and low potential for both water quality improvements and downstream flow benefits to the Blackfoot River. The lower reaches of the East Fork support high densities of fluvial WSCT. Fisheries impairments, located in the lower reaches, are believed to include elevated instream sediment levels from poor road drainage. The new culvert may also restrict upstream movement of juvenile fish. The East Fork of Chamberlain tested negative for whirling disease despite positive results for whirling disease in the mainstem of Chamberlain Creek. 
TMDL Issues

Not listed

Dewatering Issues

None

Native Species Issues

Fluvial WSCT spawning stream

WSCT genetic composition: untested

Restoration Activities

Past Restoration

A culvert was upgraded. Some erosion control work on Plum Creek properties was completed in the mid-1990s.

Current/Planned Restoration

None

\section{Monitoring Activities}

\section{Past Monitoring}

FWP inventoried fish populations in 1997 and measured stream temperatures in 1999 and 2000. FWP tested for whirling disease in 1999 and 2000.

\section{Ongoing Monitoring}

None

Planned Future Monitoring

None

\section{HOGUM CREEK: Priority - Moderate \\ Description}

Hogum Creek, a 2nd order tributary to the upper Blackfoot river, flows $\sim 6$ miles through both public (National Forest) in headwaters and private land downstream of mile $\sim 2$. Hogum Creek ranks moderate in total rank and restoration priority. This moderate rank is due to a moderate native species value and (high) multi-species sport fishery value to the Blackfoot River. Hogum Creek ranks low in potential water quality benefits and moderate in social rank. Hogum Creek supports very limited numbers of bull trout, WSCT, brown trout and brook trout. All species, except the bull trout, show upstream increases at low densities. Headwater tributaries on the National Forest contain both WSCT and brook trout. Fisheries impairments in the lower reaches include road crossings (undersized culvert) and localized stream bank degradation from livestock.

TMDL Issues

Not listed

Dewatering Issues

None

Native Species Issues 
Bull trout rearing,

Fluvial WSCT spawning stream

WSCT genetic composition: tested $99-100 \%$ WSCT

\section{Restoration Activities}

\section{Past Restoration}

None

Current/Plamned Restoration

None

\section{Monitoring Activities}

\section{Past Monitoring}

FWP inventoried fish populations in 1995 and 1999, measured water temperatures in 2003 and stream flow in 2000. Telemetry identified this stream as a fluvial WSCT spawning stream.

\section{Ongoing Monitoring}

None

\section{Planned Future Monitoring}

None

\section{MOOSE CREEK: Priority - Moderate}

\section{Description}

Moose Creek, a small 1st order tributary to the upper Blackfoot River, flows $\sim 4$ miles through National Forest land, except for a small section of private land near the mouth. Moose Creek ranks moderate in total rank and restoration priority due to a moderate native species value, single species sport fishery value to the Blackfoot River and a high rank for social and financial considerations. Due to adequate flows and healthy riparian area, Moose Creek ranks low in potential to improve water quality and provides no potential for increasing flows to the Blackfoot River. Moose Creek supports a population of fluvial WSCT. Fishery impairments near the mouth include placer mining and two undersized culverts that partially limit upstream fish passage.

\section{TMDL Issues}

Not listed

\section{Dewatering Issues}

None

Native Species Issues

WSCT genetic composition: tested $99-100 \%$ WSCT

\section{$\underline{\text { Restoration Activities }}$}

\section{Past Restoration}

None

Current/Planned Restoration 
The USFS and others are planning to replace an undersized culvert near the mouth and remove a second culvert.

\section{Monitoring Activities}

Past Monitoring

FWP inventoried fish populations in 1999 and measured stream temperatures in 2002 and 2003 and stream flows in 2000 and 2004.

\section{Ongoing Monitoring}

None

Planned Future Monitoring

None

\section{BASIN SPRING CREEK: Priority - Moderate}

\section{Description}

Basin Spring Creek is a $1^{\text {st }}$ order spring creek tributary to lower Pearson Creek, a lower Chamberlain Creek tributary. This stream flows $\sim 0.15$ miles exclusively through private agricultural land. Basin Spring Creek ranked moderate on the restoration priority list, moderate on the native species priority list and low on the biological priority list. Restoration efforts on Basin Creek in the early 1990's included channel reconstruction, shrub planting and grazing management changes. We have no identified current impairments on this stream. Basin Spring Creek serves as a migration corridor for fluvial WSCT to Pearson Creek and supports low densities of resident brook trout.

\section{TMDL Issues}

Not listed

\section{Dewatering Issues}

None

\section{Native Species Issues}

Fluvial WSCT migration corridor

\section{Restoration Activities}

\section{Past Restoration}

The upper section of this stream was reconstructed in 1995. The project involved wetland enhancement and riparian grazing changes.

Current/Planned Restoration

None

\section{Monitoring Activities}

Past Monitoring

FWP conducted fish population surveys in 1991, 1995 and 1997.

Ongoing Monitoring

None

\section{Planned Future Monitoring}

None 


\section{BLACK BEAR CREEK: Priority - Moderate Description}

Black Bear Creek, a small $1^{\text {st }}$ order tributary to Bear Creek in the upper Douglas Creek watershed, flows $\sim 7.5$ through both public (BLM) and private agricultural land. The upper reaches are public land. Black Bear Creek ranks moderate on the restoration priority list despite a high rank in potential water quality benefits, but does not support fish, resulting in a low biological and native species rank. Riparian impairments in the lower reaches include: 1) livestock induced stream bank degradation and riparian vegetation suppression, 2) a crushed and undersize culvert, and 3) reduced instream flow from irrigation.

\section{TMDL Issues}

Listing history: 1996-Yes; 2000-Yes; 2002-Yes; 2004-Yes.

Listed causes of impairment: Habitat alterations, siltation, phosphorus, and suspended solids.

\section{Dewatering Issues}

unknown

\section{Native Species Issues}

No native fish present

\section{$\underline{\text { Restoration Activities }}$}

\section{Past Restoration}

None

Current/Planned Restoration

None

\section{Monitoring Activities}

Past Monitoring

FWP conducted electrofishing surveys and measured flows in 2000.

\section{Ongoing Monitoring}

None

Planned Future Monitoring

None

\section{BLACKFOOT RIVER (Reach 6: Clearwater River to the mouth): Priority - Moderate \\ Description}

The lower reach of the Blackfoot River extends 34.7 from the mouth of the Clearwater River (mile 34.7) downriver to the confluence with the Clark Fork River. It flows through private, agricultural and industrial forest (Plum Creek) and public (BLM, State) lands. Several tributaries enter this reach of the Blackfoot River. In the downstream direction, they are Fish Creek, Little Fish Creek, Elk Creek, Belmont Creek, Gold Creek, Union Creek, Bear Creek, East and West Twins and Johnson Creek. This reach ranks 
moderate in total ranking due to a high native species value, high social and financial considerations, low sport fishery value due to a lack of mainstem spawning and low potential of improving downstream water quality. This reach supports the highest salmonid densities in the Blackfoot River. The salmonid assemblage includes rainbow trout as the dominant fish, followed by brown trout, WSCT and bull trout. The majority of bull trout in this reach reproduce in the Monture and North Fork watersheds. Milltown dam located at the mouth of the Blackfoot River represents the largest fisheries impairment in the system. Lesser habitat related mainstem fisheries impairments are localized and include: 1) channel alterations, 2) lacks complexity, 3) road drainage, 4) livestock suppressed riparian vegetation and stream bank damage and 5) recreational impacts in the form of stream bank damage. This reach now supports moderate to high levels of whirling disease.

\section{TMDL Issues}

Listed

\section{Dewatering Issues}

Although this river reach is subject to upstream dewatering, it is not on the dewatered stream list due to generally sufficient flows except during drought.

\section{Native Species Issues}

Nodal bull trout habitat; proposed critical bull trout habitat, nodal bull trout habitat Junctions of cold tributaries considered bull trout recovery/ recreational conflict areas

\section{$\underline{\text { Restoration Activities }}$}

\section{Past Restoration}

None

\section{Current/Planned Restoration}

None

\section{Monitoring Activities}

\section{Past Monitoring}

A USGS flow monitoring station (\#1234000) established at river mile 7.9 has 68 years of flow data. FWP established the Johnsrud fish population survey section in 1982, continuous summer water temperature sites monitoring in 1993, and sentinel cage whirling disease monitoring sites in 1997. Water quality and macro-invertebrates were assessed at four locations in 1998-89 (Ingman et al. 1990). A riparian health inventory was conducted in 1999 from Corrick River bend to the mouth of Gold Creek, with noxious weeds, erosion and channel incision as the focus (Marler and Schmetterling 1999).

\section{Ongoing Monitoring}

FWP conducts bi-annual fish population surveys in the Johnsrud Section. USGS flow monitoring at the Bonner gauging station is continuous. FWP expects to continue to monitor summer water temperature data and whirling disease on an annual basis in this river reach.

Planned Future Monitoring 
None beyond expected ongoing monitoring.

\section{GRANTIER SPRING CREEK: Priority - Moderate}

\section{Description}

Grantier Spring Creek is a spring-fed tributary to the upper Blackfoot River, located on private land. Grantier Spring Creek was the focus of extensive restoration over the past several years including channel reconstruction, habitat restoration and riparian land management changes. Grantier Spring Creek supports low densities of bull trout and fluvial WSCT as well as brown trout and brook trout, giving rise to a multi-species sport fishery value to the Blackfoot River and a high native species value. Because of restoration efforts, it now has low potential water quality benefits to the Blackfoot River. No fisheries impairments are present at this time.

\section{TMDL Issues}

Not listed

Dewatering Issues

None

Native Species Issues

Adult bull trout use, likely historical bull trout spawning

Fluvial WSCT migration corridor

\section{Restoration Activities}

Past Restoration

Grantier Spring Creek was reconstructed in the early-mid 1990s. The project involved grazing management improvements.

Current/Planned Restoration

None

\section{Monitoring Activities}

\section{Past Monitoring}

FWP conducted fish population surveys in 1991 and 1994, measured water temperatures in 2001 and stream flows in 1989. FWP monitored whirling disease in 1997 and 2004.

\section{Ongoing Monitoring}

None

Planned Future Monitoring

None

\section{SEVEN UP PETE CREEK: Priority - Moderate}

\section{Description}

Seven Up Pete Creek, a 1st order tributary to the upper Blackfoot River drains the slopes of Crater Mountain and flows $\sim 5$ miles through both National Forest and private land. Private land is located only between mile 3 and 4 . Seven Up Pete Creek ranks moderate in restoration priority and total rank. This rank is due to moderate native species values and single species sport fishery value to the Blackfoot River. Seven Up Pete Creek ranks 
low for potential to improve water quality in the Blackfoot River. Seven Up Pete Creek supports low densities of genetically pure fluvial WSCT and brook trout. Fisheries impairments include mining practices in headwater areas and an ATV trail that fords the stream a minimum of 15 times.

TMDL Issues

Not listed

Dewatering Issues

Unknown

Native Species Issues

WSCT genetic composition: tested $100 \%$ WSCT

Restoration Activities

Past Restoration

None

Current/Plamned Restoration

None

Monitoring Activities

Past Monitoring

FWP inventoried fish population in 1999.

Ongoing Monitoring

None

Planned Future Monitoring

None 


\section{LOW PRIORITY STREAMS}

\section{ASHBY CREEK: Priority - Low}

Description

Ashby Creek, a $2^{\text {nd }}$ order tributary to Camas Creek in the Union Creek watershed, flows $\sim 8$ miles through public land in upper reaches and private agricultural land in the lower $\sim 5.5$ miles. Ashby Creek ranks low on the restoration priority list. Low native species value and lack of sport fishery value contributes this ranking, despite high potential for downstream water quality benefits. Ashby Creek supports a genetically pure population of resident WSCT along with brook trout and ranks moderate on the native species priority list. Densities are generally low for both species, although WSCT numbers increase in the upstream direction. Fisheries-related impairments, located in the middle and lower reaches, include 1) irrigation (seasonal fish passage and dewatering), 2) severe channel alterations, 3) lack of complex fish habitat, 4) excessive livestock access to riparian areas, and 5) elevated sediment from road drainage.

\section{TMDL Issues}

Listed

\section{Dewatering Issues}

Channel alterations and inter-basin transfers to Arkansas Creek have caused dewatering for $\sim 2.5$ miles of Ashby Creek.

\section{Native Species Issues}

WSCT genetic composition: tested $100 \%$ WSCT

\section{Restoration Activities}

\section{Past Restoration}

None

\section{Current/Planned Restoration}

Five Valleys Land Trust is taking the lead to secure a conservation easement to restore a portion of Ashby Creek and surrounding wetlands.

\section{Monitoring Activities}

\section{Past Monitoring}

FWP inventoried fish population in 2000 and measured water temperatures in 2002.

\section{Ongoing Monitoring}

None

\section{Planned Future Monitoring}

Additional monitoring plans will be developed in conjunction with final restoration plans.

\section{BEAR CREEK (rm 37.5): Priority - Low \\ Description}

Bear Creek, a small, $2^{\text {nd }}$ order tributary to the middle Blackfoot River, flows $\sim 4$ miles through public (BLM) and private land in middle reaches. A lack of potential water quality benefits, moderate native species value and moderate biological ranking 
characterizes Bear Creek's low total ranking on the restoration priority list. Bear Creek supports fluvial WSCT, providing low (single species) sport fishery value to the Blackfoot River. The lower reaches support low densities WSCT that increase to moderate levels in the middle and upper reaches. Fisheries impairments include undersize culverts limiting fish passage.

\section{TMDL Issues}

Not listed

\section{Dewatering Issues}

None

\section{Native Species Issues}

WSCT genetic composition: tested $96.5 \%$ WSCT

\section{Restoration Activities}

Past Restoration

None

Current/Planned Restoration

None

\section{Monitoring Activities}

Past Monitoring

FWP inventoried fish populations in 1998.

Ongoing Monitoring

None

Planned Future Monitoring

None

\section{CAMAS CREEK: Priority - Low}

\section{Description}

Camas Creek, a 3rd order tributary to Union Creek in the lower Blackfoot River water shed, flows $\sim 10$ miles through private agricultural land. Overall, Camas Creek ranks moderate on the restoration priority list. This low rank results, low native species value, and no sport fishery value to the Blackfoot River despite potential downstream water quality benefits. Camas Creek supports resident WSCT and brook trout. Fish sampling found no salmonids in the lower Camas Creek. The middle reaches support brook trout in low number, while moderate numbers of WSCT dominates the headwaters, including Smith Creek an upper tributary of Camas Creek. Fisheries impairment in the middle and lower reaches include 1) livestock-induced stream bank degradation, 2) riparian vegetation suppression, and 3) lack of complex fish habitat (instream wood).

\section{TMDL Issues}

Listed

\section{Dewatering Issues}


Unknown

Native Species Issues

WSCT genetic composition: untested

$\underline{\text { Restoration Activities }}$

Past Restoration

None

Current/Planned Restoration

None

\section{Monitoring Activities}

Past Monitoring

FWP inventoried fish populations in 2000 and measured stream temperatures in 2002.

Ongoing Monitoring

None

Planned Future Monitoring

None

\section{CHAMBERLAIN CREEK, West Fork: Priority - Low}

Description

The West Fork of Chamberlain Creek, a small, 1st order tributary to lower Chamberlain Creek, flows $\sim 2.5$ miles entirely through private (Plum Creek) lands. The West Fork ranks low on the restoration, biological, and native species priority list. The lower reaches of the West Fork likely supports fluvial WSCT. Fisheries impairments, located in the lower reaches, are elevated instream sediment levels from poor road drainage. No fish sampling data has been collected on the West Fork; however, the mainstem near the mouth of the West Fork supports high densities of fluvial WSCT along with low numbers of brook trout. The West Fork of Chamberlain Creek tested negative for whirling disease in 1999 and 2000.

\section{TMDL Issues}

Not listed

Dewatering Issues

None

Native Species Issues

\section{$\underline{\text { Restoration Activities }}$}

Past Restoration

Some erosion control and riparian grazing changes were implemented in the mid 1990s.

Current/Planned Restoration

None

$\underline{\text { Monitoring Activities }}$ 


\section{Past Monitoring}

FWP tested for whirling disease and measured stream temperatures in 1999 and 2000.

Ongoing Monitoring

None

Planned Future Monitoring

None

\section{CHICKEN CREEK: Priority - Low}

Description

Chicken Creek, a small 1st order tributary to Nevada Creek, flows $\sim 4$ miles through mainly private land with a small portion of public land (National Forest) near the headwaters. The total rank for Chicken Creek is low. This low rank comes from low native species value, no sport fishery value to the Blackfoot River despite high potential water quality benefits. Lower Chicken Creek supports low densities of resident rainbow trout, while the middle reaches support low numbers of resident WSCT. Fisheries impairments in the lower 1.5 miles include 1) livestock-induced stream channel degradation, 2) riparian vegetation suppression, 3) a lack complex fish habitat (instream wood), and 4) an undersized culvert on the National Forest.

\section{TMDL Issues}

Not listed

\section{Dewatering Issues}

Unknown

Native Species Issues

WSCT genetic composition: tested 100\% WSCT

Isolet WSCT population

\section{Restoration Activities}

\section{Past Restoration}

None

Current/Planned Restoration

None

\section{Monitoring Activities}

Past Monitoring

FWP inventoried fish populations and measured stream flows in 2000.

\section{Ongoing Monitoring}

None

Planned Future Monitoring

None

CHIMNEY CREEK (Trib. to Douglas Creek): Priority - Low

Description 
Chimney Creek, a 1st order tributary to middle Douglas Creek, flows $\sim 7.4$ miles entirely through private ranch land. Chimney Creek ranks low on the restoration priority list for non-project streams. Despite potential for downstream water quality and moderate social rank, Chimney Creek ranks low due to low native species value, and no sport fishery value to the Blackfoot River. Lower Chimney Creek supports only non-game fish species. The middle reaches support low densities of resident WSCT. Fisheries impairments include 1) livestock induced stream channel degradation and riparian vegetation suppression, 2) the lack of complex fish habitat (instream wood), and 3) channel alterations (instream reservoirs for irrigation).

TMDL Issues

Not listed

Dewatering Issues

Unknown

Native Species Issues

WSCT genetic composition: tested 100\% WSCT

$\underline{\text { Restoration Activities }}$

Past Restoration

None

Current/Planned Restoration

None

\section{Monitoring Activities}

Past Monitoring

FWP inventoried fish populations and measured stream flow in 2000.

Ongoing Monitoring

None

Planned Future Monitoring

None

\section{LITTLE MOOSE CREEK: Priority - Low Description}

Little Moose Creek is a small $1^{\text {st }}$ order tributary that drains the northern slopes of Ogden Mountain. The majority of its 1.9 miles flow through public (National Forest and State) lands. Only the lower 0.4 miles flow on private land where it empties into an isolated oxbow pond, only biologically connecting into the Blackfoot River during spring run-off. Little Moose Creek ranks low on the restoration priority and total rank list. Little Moose Creek supports very low densities of resident WSCT throughout it entire length. No known fishery impairments are present at this time.

\section{TMDL Issues}

Not Listed 


\section{Dewatering Issues}

None

Native Species Issues

WSCT genetic composition: tested $100 \%$ WSCT

\section{$\underline{\text { Restoration Activities }}$}

Past Restoration

None

Current/Planned Restoration

None

\section{Monitoring Activities}

Past Monitoring

FWP measured water temperature in 2002 and 2003. USFS inventoried fish populations.

Ongoing Monitoring

None

Planned Future Monitoring

None

\section{MURRAY CREEK: Priority - Low}

\section{Description}

Murray Creek, a 2nd order tributary to Douglas Creek, flows $\sim 8$ miles through public $(B L M)$ and private agricultural land downstream of mile $\sim 4$. Murray Creek received a low rank on the restoration priority and total rank list. This rank relates to a low native species rank, lack of a sport fishery value to the Blackfoot River despite potential to improve downstream water quality. Murray Creek supports low densities of genetically pure resident WSCT in the middle and upper reaches with densities increasing in the upstream direction. Fisheries impairments, located in the lower and middle reaches, include: 1) poor road crossings (perched and undersized culverts) and road drainage, 2) irrigation (dewatering and fish entrainment), 3) lack of instream complexity, and 4) degraded stream banks resulting from excessive livestock access to riparian areas.

\section{TMDL Issues}

Listing history: 1996-Yes; 2000, 2002, 2004-Did not meet SCD.

Listed causes of impairment: Flow and habitat alteration, thermal modifications.

\section{Dewatering Issues}

The lower three miles of Murray Creek are on the dewatered stream list due to irrigation.

Native Species Issues

WSCT genetic composition: tested 100\% WSCT

\section{Restoration Activities}

\section{Past Restoration}

None 
Current/Planned Restoration

None

\section{Monitoring Activities}

Past Monitoring

FWP inventoried fish population and measured stream flows in 2000.

Ongoing Monitoring

None

Planned Future Monitoring

None

\section{SHEEP CREEK: Priority - Low}

\section{Description}

Sheep Creek, a small 1st order tributary to Sturgeon Creek, located in the Douglas Creek watershed, flows $\sim 4$ miles exclusively through private ranch land. Sheep Creek ranks low for total rank, due to low native species value, lack of a sport fishery value, despite high potential to improve downstream water quality and a high social rank. No salmonid or other fish species were detected in Sheep Creek when it was sampled in 2000. Riparian impairments include low instream flows due to an aggraded channel and excessive livestock access to stream banks over most of the channel.

\section{TMDL Issues}

Not listed

\section{Dewatering Issues}

Unknown

\section{Native Species Issues}

No native fish present

\section{$\underline{\text { Restoration Activities }}$}

Past Restoration

None

Current/Planned Restoration

None

\section{Monitoring Activities}

Past Monitoring

FWP sampled Sheep Creek for fish in 2000.

Ongoing Monitoring

None

Planned Future Monitoring

None

WARM SPRINGS CREEK: Priority - Low

Description 
Warm Springs Creek, a small 1st order tributary to lower Gold Creek, flows $\sim 2.5$ miles primarily through private land with a small portion of public land. Warm Springs Creek ranks low for restoration priority and total rank. This low rank is due to low native species value, low (single-species) sport fishery value to the Blackfoot River and low potential for improved water quality benefits. However, Warm Springs Creek has potential to increase flow in the Blackfoot. Despite bull trout core area status, Warm Springs Creek supports low densities of resident rainbow trout and no other species. Fisheries impairments include: 1) fish passage problems at a road crossing, 2) excess road drainage, and 3) irrigation impacts.

\section{TMDL Issues}

Not listed

\section{Dewatering Issues}

The lower mile of Warm Springs Creek in on the dewatered stream list due to irrigation.

Native Species Issues

Bull trout core area stream

WSCT not detected

\section{$\underline{\text { Restoration Activities }}$}

\section{Past Restoration}

None

Current/Planned Restoration

None

\section{Monitoring Activities}

\section{Past Monitoring}

FWP inventoried fish populations in 1998.

\section{Ongoing Monitoring}

None

Planned Future Monitoring

None

\section{FINN CREEK: Priority - Low}

\section{Description}

Finn Creek, a small 2nd order tributary to upper Nevada Creek, flows $\sim 3.3$ miles entirely through private ranch land. Finn Creek ranks low in total ranking and currently has no native species or sport fishery value to the Blackfoot River, but did rank high in potential water quality benefits. No fish were collected on Finn Creek when it was sampled in 2001. Fisheries impairments in the lower $\sim 2$ miles include: 1 ) low flows due to an aggraded channel, 2) livestock-induced stream bank degradation and riparian vegetation suppression, and 3) lack of complex fish habitat (instream wood).

\section{TMDL Issues}

Not listed 


\section{Dewatering Issues}

Unknown

Native Species Issues

No native fish present

Restoration Activities

Past Restoration

None

Current/Planned Restoration

None

\section{Monitoring Activities}

\section{Past Monitoring}

FWP inventoried fish population in 2001.

Ongoing Monitoring

None

\section{Planned Future Monitoring}

None

\section{HALFWAY CREEK: Priority -Low}

Description

Halfway Creek, a $3^{\text {rd }}$ order stream, flows northwest 8.5 miles through private ranchland and enters Nevada Creek at mile 40.3. Halfway Creek ranks low in the total ranking due to a low native species value, lack of sport fishery value to the Blackfoot River and moderate social and financial rank. Halfway Creek ranked high in potential to improve downstream water quality including temperature, sediment and nutrients. No salmonids were collected at two sampling sites in Halfway Creek in 2001. Fish species were limited to redside shiner, longnose sucker and sculpin. Spotted frogs and western toads were also observed. Fisheries impairments include: 1) degraded riparian vegetation; 2) excessive livestock access to stream banks; 3) lack of instream complexity; 4) high sediment levels; and 5) thermal modification.

TMDL Issues

Not listed

Dewatering Issues

Unknown

Native Species Issues

No native salmonids found

Restoration Activities

Past Restoration

None 


\section{Current/Planned Restoration}

None

\section{Monitoring Activities}

\section{Past Monitoring}

FWP inventoried fish populations and measured water temperatures and stream flow in 2001.

\section{Ongoing Monitoring}

None

Planned Future Monitoring

None

\section{MITCHELL CREEK: Priority - Low \\ Description}

Mitchell Creek, a 1st order tributary to Nevada Creek, flows $\sim 7$ miles through a combination of public (National Forest) land in the headwaters and private agricultural land downstream of mile $\sim 4$. Mitchell Creek ranks low in restoration priority and total rank due to low native species value, lack of sport fishery value to the Blackfoot River, and moderate potential to improve downstream water quality. The only salmonid present in Mitchell Creek is resident WSCT in low to moderate densities. Fisheries impairments in middle reaches include 1) an undersized culvert near the mouth, 2) a general lack complex fish habitat, and 3) livestock access to stream banks.

\section{TMDL Issues}

Not listed

\section{Dewatering Issues}

Unknown

\section{Native Fish Issues}

WSCT genetic composition: untested

Restoration Activities

Past Restoration

None

Current/Plammed Restoration

None

\section{Monitoring Activities}

\section{Past Monitoring}

FWP inventoried fish populations and measured stream temperatures and stream flows in 2001.

\section{Ongoing Monitoring}

None

Planned Future Monitoring

None 


\section{STURGEON CREEK: Priority - Low \\ Description}

Sturgeon Creek, a small 3rd order tributary to Douglas Creek, flows $\sim 4$ miles exclusively through private ranch land. Sturgeon Creek ranks low on the restoration priority and total rank list. This low rank is due to lack of native species and absence of sport fishery value to the Blackfoot River. However, Sturgeon Creek ranks high for potential to improve downstream water quality. No salmonids were sampled in Sturgeon creek, but a small spring creek tributary supports a small disjunct population of resident WSCT. Fisheries impairments located throughout the drainage include: 1) channel alterations (instream reservoir), 2) degraded riparian vegetation, 3) inadequate instream flow, and 4) excessive livestock access to stream banks.

\section{TMDL Issues}

Not listed

\section{Dewatering Issues}

Unknown extent

\section{Native Species Issues}

WSCT genetic composition: tested $100 \%$ WSCT in the spring creek

\section{Restoration Activities}

\section{Past Restoration}

None

\section{Current/Planned Restoration}

None

\section{Monitoring Activities}

Past Monitoring

FWP inventoried fish population and measured stream flows in 2000.

Ongoing Monitoring

None

\section{Planned Future Monitoring}

None

\section{WASHOE CREEK: Priority - Low \\ Description}

Washoe Creek, a small 1st order stream, flows $\sim 6.2$ miles through public land (BLM) in headwaters and private ranch land downstream of mile $\sim 3.5$. Washoe Creek ranks low on the restoration priority and total ranking list. This low rank is due to low native species value, lack of sport fishery value to the Blackfoot River and potential to improve downstream water quality. Washoe Creek ranks moderate for social and financial consideration. Washoe Creek supports resident WSCT. Fisheries impairments in the lower Washoe Creek include excessive livestock access to stream banks and lack of instream complexity. 
TMDL Issues

Listed

Dewatering Issues

Unknown

Native Species Issues

WSCT genetic composition: tested $99 \%$ WSCT

Restoration Activities

Past Restoration

None

Current/Planned Restoration

None

Monitoring Activities

Past Monitoring

FWP inventoried fish populations in 2000 and 2002 and measured water temperatures in 2002.

Ongoing Monitoring

None

Planned Future Monitoring

None

\section{ARKANSAS CREEK: Priority - Low}

\section{Description}

Arkansas Creek, a small $1^{\text {st }}$ order tributary to Ashby Creek in the Union Creek watershed, flows 5 miles through private (Plum Creek and agricultural) land. It ranks moderate in potential water quality benefits, low in native species value, and provides no sport fishery value to the Blackfoot River, giving Arkansas Creek a low total ranking on the restoration priority list. Arkansas Creek supports pure resident WSCT and brook trout in its lower and middle reaches. WSCT densities are low but increase slightly in the upstream direction, while brook trout densities are low. Fisheries impairments include: 1) elevated stream sediment levels from poor road drainage, 2) extensive channel alterations in mid-to lower reaches, 3) livestock induced bank degradation, and 4) dewatering.

\section{TMDL Issues}

Not listed

\section{Dewatering Issues}

The lower two miles of Arkansas Creek is on the dewatered stream list due to irrigation.

Native Species Issues

WSCT genetic composition: tested 100\% WSCT 


\section{Restoration Activities}

\section{Past Restoration}

None

\section{Current/Planned Restoration}

The NRCS, Five Valleys Land Trust and the principle landowner are planning a comprehensive stream and wetland restoration project in the lower reaches of Ashby Creek. This project may involve lower Arkansas Creek.

\section{Monitoring Activities}

\section{Past Monitoring}

FWP inventoried fish populations 2000 and measured stream temperatures in 2002.

\section{Ongoing Monitoring}

None

\section{Planned Future Monitoring}

Additional monitoring will be developed in conjunction with restoration plans.

\section{BUFFALO GULCH: Priority - Low \\ Description}

Buffalo Gulch, a small 2nd order tributary to the Nevada Creek Reservoir, flows $\sim 7$ miles through both public (National Forest) in headwaters and private land in the lower $\sim 4$ miles of stream. Buffalo Gulch ranks high in potential water quality benefits, moderate in native species value, and provides no sport fishery value to the Blackfoot River, resulting in a low total rank for restoration priority. Lower Buffalo Gulch supports moderate densities of resident WSCT and low densities of rainbow trout. Fisheries impairments in the lower $\sim 3$ miles of stream include 1) livestock-induced stream bank damage, 2) riparian vegetation suppression and 3) lack of complex fish habitat (instream wood).

\section{TMDL Issues}

Listing History: 1996-No; 2000-Yes; 2002-Yes; 2004-Yes.

Listed causes of impairment: Siltation, habitat alterations.

\section{Dewatering Issues}

Unknown

Native Species Issues

WSCT genetic composition: tested $100 \%$ WSCT

\section{$\underline{\text { Restoration Activities }}$}

\section{Past Restoration}

None

Current/Planned Restoration

None

\section{Monitoring Activities}


Past Monitoring

FWP inventoried fish population, measured flows and collected water temperature data in 2001.

Ongoing Monitoring

None although a road sediment and culvert survey on private land is recommended.

Planned Future Monitoring

None

\section{CALIFORNIA GULCH: Priority - Low}

Description

California Gulch, a small 2nd order tributary to Buffalo Gulch in the upper Nevada Creek watershed, flows $\sim 3.5$ miles through both public (National Forest) and private land in the lower $\sim 2$ miles. High potential water quality benefits, low native species value, low social rank, and no sport fishery value to the Blackfoot River, ranks California Gulch low on the restoration priority list for non-project streams. California Gulch supports only resident WSCT. Fisheries impairments in the lower $\sim 2$ miles include 1) lack of complex fish habitat (instream wood), 2) livestock-induced stream bank degradation and riparian vegetation suppression, and 3 ) reduced instream flows from irrigation.

TMDL Issues

Not listed

Dewatering Issues

Unknown

Native Species Issues

WSCT genetic composition: untested

Restoration Activities

Past Restoration

None

Current/Planned Restoration

None

\section{Monitoring Activities}

Past Monitoring

FWP inventoried fish populations and measured stream flow in 2001.

Ongoing Monitoring

None

Planned Future Monitoring

None

COTTONWOOD CREEK (Trib. to Douglas Creek): Priority - Low

Description

Cottonwood Creek, a 2nd order tributary to lower Douglas Creek, flows $\sim 18$ miles first through public (BLM) and then private agricultural land in the lower $\sim 8$ miles of the 
stream. Overall, it ranks low on the restoration priority list. A low native species value, low social ranking, and lack of sport fishery value generate its low total and biological ranking. Due to dewatering, potential for a reduction in sediment, temperature and nutrients, Cottonwood Creek ranks high in potential water quality benefits. The upper reaches support high densities of resident WSCT and brook trout. Lower Cottonwood Creek supports only long nose suckers. Fisheries impairments, located in the lower reaches, include: 1) livestock induced stream bank degradation and riparian vegetation suppression, 2) lack of complex fish habitat (instream wood), 3) undersize road crossing culverts causing erosion, and 4) dewatering.

\section{TMDL Issues}

Listing history: 1996-Unknown; 2000-Yes; 2002-Yes; 2004-Yes.

Listed causes of impairment: Siltation, thermal modification, nutrients, salinity, TDS, chlorides.

\section{Dewatering Issues}

The lower five miles of Cottonwood Creek is on the dewatered stream list due to irrigation.

\section{Native Species Issues}

WSCT genetic composition: tested 100\% WSCT

\section{Restoration Activities}

\section{Past Restoration}

Some restoration work has occurred in the lower basin. Projects involved riparian grazing improvements, instream restoration and fish ladders at diversions.

\section{Current/Planned Restoration}

None

\section{Monitoring Activities}

\section{Past Monitoring}

FWP inventoried fish population since 1998 and 2000 and measured water temperatures and stream flows in 2000.

\section{Ongoing Monitoring}

None

\section{Planned Future Monitoring}

None

\section{JEFFERSON CREEK: Priority - Low \\ Description}

Jefferson Creek, a 2nd order tributary to Nevada Creek, drains the eastern slopes of Dalton Mountain and flows 7.5 miles entirely through private land except for a section of public (BLM) land between mile 4 and 5. Jefferson Creek ranks low in the total ranking and restoration priority list. This rank is due a low (single) native species value, lack of sport fishery value to the Blackfoot River and low social and financial rank. Jefferson Creek ranked high in potential to improve downstream water quality due to its 
impaired condition. Jefferson Creek supports populations of resident WSCT and rainbow trout. Rainbow trout are found in low numbers in lower reaches. WSCT are found throughout the drainage in generally low densities. Fisheries impairments in the upper and middle reaches include: 1) poor road crossings (crushed undersized culvert), 2) channel alterations (mining disturbance), 3) lack of instream complexity, and 4) low instream flow.

\section{TMDL Issues}

Listing history: 1996-Yes; 2000-Yes; 2002-Yes; 2004-Yes.

Listed causes of impairment: Flow and habitat alteration, siltation, suspended solids, and metals.

\section{Dewatering Issues}

The lower mile of Jefferson Creek is on the dewatered stream list due to irrigation.

\section{Native Species Issues}

WSCT genetic composition: tested $93 \%$ WSCT

\section{$\underline{\text { Restoration Activities }}$}

Past Restoration

None

Current/Planned Restoration

None

\section{Monitoring Activities}

\section{Past Monitoring}

FWP inventoried fish populations and measured stream temperatures and stream flow in 2001.

\section{Ongoing Monitoring}

None

\section{Planned Future Monitoring}

None

\section{NEVADA CREEK (Lower): Priority - Low \\ Description}

Nevada Creek below the reservoir is a large 3rd order tributary to the middle Blackfoot River that flows $\sim 33$ miles exclusively through private ranch land. Lower Nevada Creek ranks low on the restoration priority and total rank list due to the lack of native species and sport fishery values to the Blackfoot River. Although Nevada Creek ranks low overall, it ranked high for potential to increase flow and potential to improve downstream water quality to the Blackfoot River. Salmonids (rainbow trout and brown trout) inhabit lower Nevada Creek in very low densities immediately below Nevada Creek reservoir, but are absent from lower Nevada Creek. Fisheries-related impairments, located throughout the drainage, include: 1) irrigation impacts (entrainment, dewatering), 2) channel alterations, 3) lack of instream complexity, 4) degraded riparian vegetation 
resulting from excessive livestock access to riparian areas, and 5) low water quality. In 2003, low levels of whirling disease were detected in Nevada Creek.

\section{TMDL Issues}

Listing history: 1996-Yes; 2000-Yes; 2002-Yes; 2004-Yes.

Listed causes of impairments: Flow and habitat alterations, nutrients, and siltation.

\section{Dewatering Issues}

The lower 25.3 miles of lower Nevada Creek is on the dewatered stream list due to reservoir management and irrigation.

\section{Native Species Issues}

WSCT not detected in lower Nevada Creek

\section{Restoration Activities}

\section{Past Restoration}

Grazing related projects have been completed in some portions of lower Nevada Creek, Fish ladder were installed on several irrigation diversions.

\section{Current/Planned Restoration}

Restoration activities are ongoing and focus on grazing issues.

\section{Monitoring Activities}

\section{Past Monitoring}

FWP inventoried fish population in 1989 and 1990 and resurveyed sample sites in 1994 and 2000. FWP measured stream temperatures annually from 1998 through 2004 and stream flows in 1989, 2000 and 2001. A USGS gauging station monitors stream flows near the mouth of Nevada Creek and a DNRC gauging station monitors flows below the reservoir. FWP tested for whirling disease below the reservoir in 2003. An ambient water quality survey was completed in 1989 (Ingman et al. 1990).

\section{Ongoing Monitoring}

Water temperature assessments are ongoing

Planned Future Monitoring

Periodic fish population will be completed.

\section{WASHINGTON CREEK: Priority - Low \\ Description}

Washington Creek, a 2nd order tributary to upper Nevada Creek, flows $\sim 11$ miles through mixed public (National Forest, BLM) and private ownership. Washington Creek ranks low for non-project streams on the restoration priority and total rank list. This low rank is due to: 1) low native species value, 2) lack of sport fishery value to the Blackfoot River, and 3) low social and financial rank. Washington Creek ranks high for potential to improve downstream water quality if restored due to its impaired condition. Washington Creek contains resident WSCT and resident brook trout throughout the drainage. Densities of WSCT decrease in the downstream direction. Brook trout are present in low densities from a fish barrier (mile 7.2) downstream to the mouth. Fisheries impairments are extensive and include: 1) channel alterations related to past placer mining irrigation, 
2) channel alterations near the mouth, 3) lack of instream complexity, 4) stream bank damages resulting from excessive livestock access to riparian areas, and 5) at least one road crossing at site identified by the USFS.

\section{TMDL Issues}

Listed

\section{Dewatering Issues}

The lower mile of Washington Creek in on the dewatered stream list due to irrigation.

Native Species Issues

Isolet WSCT population,

WSCT genetic composition: untested

\section{Restoration Activities}

\section{Past Restoration}

None

\section{Current/Planned Restoration}

None although a potential project would be the improvement of a fish passage barrier located at the upper end of the patented mining claim to prevent upstream invasion of brook trout.

\section{Monitoring Activities}

Past Monitoring

FWP inventoried fish populations, measured stream temperatures and collected stream flow data in 2001.

\section{Ongoing Monitoring}

None

\section{Planned Future Monitoring}

None

\section{BARTLETT CREEK: Priority - Low \\ Description}

Bartlett Creek, a 1st order tributary to Alice Creek in the upper Blackfoot River watershed, flows $\sim 7$ miles through private land and a small portion of public land (National Forest) in the upper reaches. Bartlett Creek ranks low on the restoration priority list. This low ranking is the result of low native species value, lack of sport fishery value and low potential downstream water quality benefits to the Blackfoot River. Bartlett Creek supports populations WSCT and brook trout. Fish densities are very low for both species in the lower reaches. High densities of brook trout were the only species found in the middle reaches. Fisheries impairments in lower Bartlett Creek include lack of complex fish habitat (instream wood) and localized recreational degradation (campsites) to stream banks.

\section{TMDL Issues}

Not listed 


\section{Dewatering Issues}

Natural dewatering occurs in the middle reaches the extent of which is unknown.

Native Species Issues

WSCT genetic composition: tested $98.8 \%$ WSCT

\section{$\underline{\text { Restoration Activities }}$}

Past Restoration

None

Current/Planned Restoration

None

Monitoring Activities

Past Monitoring

FWP inventoried fish populations in 1999

Ongoing Monitoring

None

Planned Future Monitoring

None

\section{FRAZIER CREEK: Priority - Low}

\section{Description}

Frazier Creek, a small 2nd tributary to the middle Blackfoot River, flows $\sim 3.6$ miles through both public (BLM) and private land. The private land is located in the lower two-thirds of the stream. Frazier ranks low on the restoration priority list due to its low native species value, low social and financial rank, lack of sport fishery value to the Blackfoot River and a technical inability to address the entire stream system. However, Frazier has moderate potential for water quality benefits and potential to increase stream flows to Blackfoot River. Frazier Creek supports a disjunct resident population of genetically pure WSCT and no other fish species. Fisheries impairments include: 1) reduced instream flows, 2) channel alterations (two instream reservoirs), 3) stream channel fragmentation preventing fish passage, and 4) livestock grazing impacts to riparian areas.

\section{TMDL Issues}

Listing history: 1996-Yes; 2000-Yes; 2002-Yes; 2004-Yes

Listed causes of impairment: Flow and habitat alteration, siltation, riparian degradation, and phosphorus.

\section{Dewatering Issues}

The lower 1.5 miles of Frazier Creek is dewatered stream list due to irrigation.

Native Species Issues

Isolate WSCT Population

WSCT genetic composition: tested 100\% WSCT 


\section{Restoration Activities}

\section{Past Restoration}

None

Current/Planned Restoration

None

\section{Monitoring Activities}

\section{Past Monitoring}

FWP inventoried fish populations in 2000 and measured stream temperatures near the mouth in 2002 and 2003.

\section{Ongoing Monitoring}

None

Planmed Future Monitoring

None

\section{GALLAGHER CREEK: Priority - Low}

\section{Description}

Gallagher Creek, a 2nd order tributary to upper Nevada Creek, flows $\sim 7$ miles through both public (National Forest) land in headwaters and private land downstream of mile $\sim 3$. Low native species value, low water quality benefits, and no sport fishery value to the Blackfoot River, ranks Gallagher Creek low on the restoration priority list. Gallagher Creek supports only resident WSCT. The lower reaches support low densities of WSCT that increase to moderate numbers in middle reaches. Fisheries impairments in lower reaches include localized livestock-induced stream bank damage and an undersized culvert.

\section{TMDL Issues}

Listing history: 1996-Yes; 2000-Yes; 2002-Yes; 2004-Yes.

Listed causes of impairments: Flow and habitat alterations, siltation, and phosphorus.

\section{Dewatering Issues}

The lower three miles of Gallagher Creek is on dewatered stream list due to irrigation.

Native Species Issues

$\underline{\text { Restoration Activities }}$

Past Restoration

None

Current/Planned Restoration

None

\section{Monitoring Activities}

Past Monitoring

FWP inventoried fish populations and measured stream flow in 2001.

Ongoing Monitoring 
None

Additional Planned Monitoring

None

\section{GAME CREEK: Priority - Low}

Description

Game Creek, a 1st order tributary to Union Creek, flows $~ 5.6$ miles through industrial forest (Plum Creek) and State land in the headwaters and private ranch land downstream of mile $\sim 2$. Low native species value, low social ranking, lack of sport fishery value to the Blackfoot River and moderate potential in water quality improvement benefits, ranks Game Creek low on the restoration and total rank priority list. Lower Game Creek supports resident WSCT. Fisheries impairments in middle reaches include localized livestock induced stream bank damage and a perched culvert limiting fish passage.

TMDL Issues

Not listed

\section{Dewatering Issues}

Unknown

Native Species Issues

WSCT genetic composition: tested $98.7 \%$ WSCT

\section{Restoration Activities}

Past Restoration

None

Current/Planned Restoration

None

\section{Monitoring Activities}

Past Monitoring

FWP inventoried fish populations in 2000 .

\section{Ongoing Monitoring}

None

Planned Future Monitoring

None

\section{HUMBUG CREEK: Priority - Low \\ Description}

Humbug Creek, a small 2nd order disjunct tributary to Poorman Creek, is located on the south side of the Lincoln Valley. Humbug Creek flows $\sim 3$ miles exclusively through private land. Humbug Creek ranks low in the total rank and restoration priority list. This rank is due to a low native species value, no sport fishery value to the Blackfoot River, low potential to improve downstream water quality and a moderate social and financial rank. Humbug Creek supports moderate densities of resident WSCT. Fisheries impairments in the lower reaches include: 1) dewatering, 2) channel alterations, 3) 
degraded riparian vegetation, 4) excessive livestock access to stream banks, and 5) a small mine in the South Fork, which contributes to channel instability.

TMDL Issues

Not listed

Dewatering Issues

The lower mile of Humbug Creek is on the dewatered stream list due to natural losses.

Native Species Issues

Isolet WSCT population

WSCT genetic composition: tested 100\% WSCT

\section{Restoration Activities}

Past Restoration

None

Current/Planned Restoration

A project is being planned to convert irrigation form the Blackfoot River to a groundwater source.

\section{Monitoring Activities}

Past Monitoring

FWP inventoried fish populations in 1995.

Ongoing Monitoring

None

Planned Future Monitoring

None

\section{SHINGLE MILL CREEK: Priority - Low \\ Description}

Shingle Mill Creek, a 1st order tributary to upper Nevada Creek, originates on the western slope of Nevada Mountain. Shingle Mill Creek flows 5.5 miles mostly through public (National Forest) with private ranch land in lower reaches. Shingle Mill Creek ranks low on the restoration and total rank list due to low native species value, low potential for improving water quality and lack of sport fishery value to the Blackfoot River. Shingle Mill Creek supports resident WSCT, with population densities that decrease in the downstream direction. Fisheries impairments in the lower reaches include irrigation impacts (dewatering and passage) and excessive livestock access to stream banks.

TMDL Issues

Not listed

Dewatering Issues

Unknown 
Native Species Issues

WSCT genetic composition: tested 100\% WSCT

\section{Restoration Activities}

Past Restoration

None

Current/Planned Restoration

None

\section{Monitoring Activities}

\section{Past Monitoring}

FWP inventoried fish populations in 2001 and measured stream flows in 2001.

Ongoing Monitoring

None

Planned Future Monitoring

None

BEAR CREEK (Trib. to the North Fork): Priority - Low

\section{Description}

Bear Creek, a small spring-fed $2^{\text {nd }}$ order disjunct tributary of the North Fork Blackfoot River, flows $\sim 2$ miles through private land. Bear Creek ranks low on the restoration priority list, despite bull trout core area status. Bear Creek has a moderate native species value due to core area status, but lacks potential water quality benefits and provides no sport fishery value. Bear Creek supports low densities of genetically unaltered resident WSCT and no other fish species. Fisheries impairments in lower Bear Creek include dewatering and possibly WSCT entrainment to irrigation canals.

TMDL Issues

Not listed

\section{Dewatering Issues}

Both natural and human-caused dewater approximately one mile of lower Bear Creek.

\section{Native Species Issues}

Isolet WSCT population

WSCT genetic composition: tested $100 \%$ WSCT

\section{$\underline{\text { Restoration Activities }}$}

\section{Past Restoration}

None

Current/Planned Restoration

None

\section{Monitoring Activities}

Past Monitoring

FWP inventoried fish population in 1998. 


\section{Ongoing Monitoring}

None

Planned Future Monitoring

None

\section{STRICKLAND CREEK: Priority - Low}

\section{Description}

Strickland Creek, a 2nd order tributary to Halfway Creek, originates on the northern slopes of Gravely Mountain in the Garnet Mountain range. Strickland Creek flows $~ 6.5$ miles exclusively through private ranch land. Strickland Creek ranks low in total rank and restoration priority due to lack of native species, no sport fishery value to the Blackfoot River, and low social and financial rank. However, Strickland Creek has high potential to improve downstream water quality. No salmonids were collected in lower Strickland Creek when it was sampled in 2001. Fisheries impairments on lower Strickland Creek include lack of instream complexity and degraded stream banks from excessive livestock access to riparian areas.

\section{TMDL Issues}

Not listed

Dewatering Issues

Unknown

Native Species Issues

No native salmonids present

\section{Restoration Activities}

\section{Past Restoration}

None

Current/Planned Restoration

None

\section{Monitoring Activities}

\section{Past Monitoring}

FWP inventoried fish populations and measured stream flow in 2001.

\section{Ongoing Monitoring}

None

\section{Additional Planned Monitoring}

None

\section{WARD CREEK: Priority - Low}

\section{Description}

Ward Creek, 2nd order tributary to the North Fork of the Blackfoot River, originates on Arrastra Mountain and flows $\sim 17$ miles through mixed ownership, with the lower $\sim 6$ miles exclusively on private land. Ward Creek is a tributary to two large lakes (Browns and Kleinschmidt Lakes) in the Blackfoot Valley. Ward Creek ranks low for restoration 
priority and total rank. This low rank is due to lack of native species, no sport fishery value to the Blackfoot River and low social and financial rank. Ward Creek ranks high in potential to improve downstream water quality. Ward Creek does not support native salmonids, but rather low densities of resident brook trout in lower reaches and moderate densities in upper reaches. Fisheries impairments are extensive and include lack of instream complexity and degraded stream banks and riparian areas resulting from excessive riparian livestock access.

TMDL Issues

Listing history: 1996-Yes; 2000-Yes; 2002-Yes; 2004-Yes.

Listed causes of impairment: Habitat alterations, siltation.

Dewatering Issues

Unknown

Native Species Issues

No native salmonids present

Restoration Activities

Past Restoration

None

Current/Planned Restoration

Grazing management changes area planned for approximately one mile of stream.

\section{Monitoring Activities}

Past Monitoring

FWP inventoried fish populations in 2001.

Ongoing Monitoring

None

Planned Future Monitoring

None

\section{INDIAN CREEK: Priority - Low}

\section{Description}

Indian Creek, a 2nd order tributary to the Nevada Creek Reservoir, flows $\sim 4.5$ miles through mostly public (BLM) land and a small portion of private land near the mouth. Indian Creek ranks low on the total ranking and restoration priority list due to low native species value, no sport fishery value to the Blackfoot River, the lack of potential to improve water quality and a moderate social ranking. Indian creek supports resident WSCT in low densities within the lower to middle reaches. Fisheries impairments include lack of instream complexity in the lower reaches.

TMDL Issues

Not listed

Dewatering Issues 
Unknown

Native Species Issues

WSCT genetic composition: untested

Restoration Activities

Past Restoration

None

Current/Planned Restoration

None

\section{Monitoring Activities}

Past Monitoring

FWP inventoried fish populations and measured stream flow in 2001 .

Ongoing Monitoring

None

Planned Future Monitoring

None

\section{WARREN CREEK (East Fork from Doney Lake): Priority - Low}

\section{Description}

East Fork Warren Creek, a $2^{\text {nd }}$ order tributary stream to Warren Creek, drains the southeastern slopes of Ovando Mountain. The upper one mile of stream is on public land (State) then flows predominately south $\sim 3.8$ miles through private industrial forest land (Plum Creek) and ranch land to its confluence with the main-stem Warren Creek (mile 8.6). At stream mile 1.6 , a small ( 0.45 mile) effluent tributary stream from Doney Lake enters. East Fork Warren Creek ranks low on the restoration priority and total ranking list because it lacks sport fishery value and potential to increase flows to the Blackfoot River. However, it ranked moderate in potential to improve downstream water quality. East Fork Warren Creek supports low numbers of WSCT and resident brook trout in its lower reaches. Fishery impairments include channel alterations and excessive livestock grazing impacts to riparian vegetation.

\section{TMDL Issues}

Not listed

Dewatering Issues

Unknown

Native species issues

No evidence of WSCT reproduction

\section{Restoration Activities}

\section{Past Restoration}

None

Current/Planned Restoration Activities 


\section{Monitoring Activities}

\section{Past Monitoring}

FWP conducted fish population surveys in 2004.

\section{Ongoing Monitoring}

None

Planned Future Monitoring

None

\section{BURNT BRIDGE CREEK: Priority - Low \\ Description}

Burnt Bridge Creek, a small 1st order tributary to Gold Creek in the lower Blackfoot River watershed, flows $\sim 2$ miles through both private land and a small portion of public land near the mouth. Burnt Bridge Creek ranks low on the restoration priority list and although located in a bull trout core area, Burnt Bridge Creek also ranks low in native species value. Burnt Bridge ranked low in biological priority due to low potential to improve downstream water quality and also currently provides no sport fishery value to the Blackfoot River. Burnt Bridge Creek supports only resident brook trout in low densities. Fisheries impairments include: 1) an entrenched and altered stream channel, 2) elevated stream sediment levels from poor road drainage, 3) undersized culverts, 4) localized areas of riparian vegetation suppression, and 5) reduced instream flows from irrigation.

TMDL Issues

Not listed

\section{Dewatering Issues}

One mile of Burnt Bridge is on the dewatered stream list due to irrigation.

Native Species Issues

Bull trout core area stream

WSCT not detected

\section{$\underline{\text { Restoration Activities }}$}

\section{Past Restoration}

None

Current/Planned Restoration

None

\section{Monitoring Activities}

Past Monitoring

FWP inventoried fish populations in 1998.

Ongoing Monitoring

None

Planned Future Monitoring 


\section{CLEAR CREEK: Priority - Low}

\section{Description}

Clear Creek, a small 2nd order tributary to Buffalo Gulch in the upper Nevada Creek watershed, flows $\sim 4$ miles through both public (National Forest) in the upper drainage and private land downstream of mile $\sim 1.5$. Clear Creek ranked low in restoration priority and total rank. Clear Creek's low priority is generated from low native species value, no sport fishery value to the Blackfoot River and lack of potential downstream water quality benefits. Clear Creek supports a resident WSCT population. Densities are low throughout the drainage, although, numbers increase in middle reaches. Fisheries impairments include at least two undersized culverts in the watershed and minor livestock damage to riparian vegetation in the middle reaches.

\section{TMDL Issues}

Not listed

Dewatering Issues

Unknown

Native Species Issues

\section{Restoration Activities}

Past Restoration

None

Current/Planned Restoration

None

\section{Monitoring Activities}

\section{Past Monitoring}

FWP inventoried fish populations and measured flow in 2001.

\section{Ongoing Monitoring}

None

\section{Planned Future Monitoring}

None

\section{FRAZIER CREEK, North Fork: Priority - Low \\ Description}

North Fork of Frazier Creek, a small 1st order tributary to Frazier Creek in the middle Blackfoot River watershed, flows $\sim 2$ miles through private timber and ranch land. The North Fork ranks low on the restoration priority list because of low native species value, low water quality benefits, no sport fishery value to the Blackfoot River and a technical inability to address the entire stream system. The North Fork supports a genetically pure population of resident WSCT. This population is disjunct from both upper Frazier Creek and the Blackfoot River due to instream irrigation reservoirs above and below the North Fork confluence. Fisheries impairments include: 1) fragmentation of stream reaches, 2) 
irrigation (entrainment and low flows), and 3) localized livestock-induced stream bank damage.

\section{TMDL Issues}

Listing history: 1996-Yes; 2000-Yes; 2002-Yes.

Listed causes of impairment: Flow and habitat alterations.

\section{Dewatering Issues}

The lower 0.5 miles of NF Frazier Creek is on the dewatered stream list due to irrigation.

\section{Native Species Issues}

Isolet WSCT

WSCT genetic composition: tested $100 \%$ WSCT

\section{$\underline{\text { Restoration Activities }}$}

\section{Past Restoration}

None

Current/Planned Restoration

None

\section{Monitoring Activities}

Past Monitoring

FWP conducted fish population surveys in 1999 and 2002.

\section{Ongoing Monitoring}

None

\section{Planned Future Monitoring}

None

\section{GLEASON CREEK: Priority - Low \\ Description}

Gleason Creek, a 1st order tributary to upper Nevada Creek, flows $\sim 4.4$ miles entirely through public (National Forest) land. With low native species value, no potential water quality benefits, and no sport fishery value to the Blackfoot River, Gleason Creek ranks low on the restoration and total rank priority list. FWP surveys report Gleason Creek supports low densities of resident WSCT with no other fish species. The USFS observed as single bull trout in a snorkeling survey in lower Gleason Creek in 1999. Fisheries impairments near the mouth of Gleason Creek include a perched culvert limiting fish passage and mining impacts.

TMDL Issues

Not listed

\section{Dewatering Issues}

None known

Native Species Issues 
WSCT genetic composition: untested

Restoration Activities

Past Restoration

None

Current/Planned Restoration

None

\section{Monitoring Activities}

Past Monitoring

FWP inventoried fish populations and measured stream flow in 2001.

Ongoing Monitoring

None

Planned Future Monitoring

None

\section{MCDERMOTT CREEK: Priority - Low \\ Description}

McDermott Creek, a small $1^{\text {st }}$ order stream, drains the southwest slopes of Mineral Hill in the Scapegoat Wilderness. This stream flows south 3.6 miles through public (National Forest) and private land before emptying into northern end of Coopers Lake. McDermott Creek received a low ranking on the restoration priority and total rank list due to a moderate native species rank, and the lack of any known impairments. McDermott Creek supports moderate densities of brook trout and very low numbers of WSCT.

TMDL Issues

Not listed

Dewatering Issues

Unknown

Native Species Issues

Bull trout core area stream

WSCT genetic composition: untested

\section{Restoration Activities}

\section{Past Restoration}

None

Current/Planned Restoration

None

\section{Monitoring Activities}

Past Monitoring

FWP conducted fish population surveys in 2001.

Ongoing Monitoring

None 
None

CHIMNEY CREEK (Nevada Creek trib. via Lincoln Slough): Priority - Low

\section{Description}

Chimney Creek, a small 1st order tributary to Lincoln Slough in the lower Nevada Creek watershed, flows $\sim 5$ miles through both public (National Forest) land in the upper drainage and private ranch land in the lower $\sim 2.5$ miles of stream. Chimney Creek ranks low in total rank due to low native species value, low social rankings, no sport fishery value, and a technical inability to address the entire stream system. Chimney Creek supports a small, low density, disjunct population of resident WSCT in middle reaches. Fisheries impairments in the lower 2 miles include: 1) localized livestock induced stream bank degradation, 2) dewatering from irrigation, 3) channel alterations, 4) undersized culverts, and 5) irrigation canals creating barriers to fish passage.

TMDL Issues

Not listed

\section{Dewatering Issues}

The lower 0.5 miles is on the dewatered stream list due to irrigation.

\section{Native Species Issues}

WSCT genetic composition: tested $100 \%$ WSCT

Isolet WSCT population

\section{Restoration Activities}

\section{Past Restoration}

None

Current/Planned Restoration

None

\section{Monitoring Activities}

\section{Past Monitoring}

FWP conducted fish population surveys in 2000.

\section{Ongoing Monitoring}

None

Planned Future Monitoring

None

\section{SMITH CREEK: Priority - Low}

\section{Description}

Smith Creek is a small $1^{\text {st }}$ order tributary stream to Camas Creek, a tributary to Union Creek in the Garnet Mountain range in the lower Blackfoot River watershed. Smith Creek flows 1.1 miles exclusively through private ranch and industrial forest land (Plum Creek). It ranks low on the restoration priority and total rank list because of its low 
native species value, no sport fishery value to the Blackfoot River, and low water quality improvement ranking. Smith Creek supports high densities of resident WSCT. Fisheries impairments include: 1) areas of livestock grazing impacts to riparian vegetation and stream banks, 2) road crossing (undersized culvert) and 3) road drainage.

TMDL Issues

Not listed

Dewatering Issues

Unknown

Native Species Issues

WSCT genetic composition: tested $99 \%$ WSCT

Restoration Activities

Past Restoration

None

Current/Planned Restoration

None

Monitoring Activities

Past Monitoring

FWP conducted fish population surveys in 2000 and 2001 near the mouth.

Ongoing Monitoring

None

Planned Future Monitoring

None 


\section{RESTORATION MONITORING PROTOCALS}

Monitoring at several spatial and temporal scales will be necessary to measure the influences of the restoration program in the Blackfoot River Watershed. At the watershed scale, ongoing long-term monitoring of mainstem fish populations (or other bioassays) will assess the broad-level influences such as 1) the cumulative condition of tributaries, 2) long-term influences of drought, 3) regional influence of disease, etc. At an intermediate scale, periodic monitoring may involve 1) sediment core data, 2) water quality samples, 3) redd counts, or 4) longitudinal surveys of fish population abundance, etc. This intermediate spatial scale of monitoring will help assess land management in sub-watersheds or the integrity of riparian areas at a tributary scale, etc. Most restoration-related monitoring will however occur at the reach or project scale. At this finer spatial scale, monitoring methods vary widely depending on the specific nature of the problem and restoration objectives. Restoration-related monitoring methods at this level are outlined below.

Restoration projects should be monitored to enhance aquatic populations and natural stream integrity. Projects should provide some baseline information (2-3 years pre-project and/or control sites) in a manner that documents the need for the project and ensures scientifically sound post-project evaluations. Sampling of wild fish will require the involvement of FWP fisheries personnel. Project effectiveness monitoring should be 1) cost-efficient, 2) practical, and 3) based on other priorities and the need for the information. Monitoring should be sufficiently robust to ensure outcomes meet project objectives, stakeholder expectations, and the public benefits associated with the project. At the very least, all habitat projects should involve pre-and post-project photo-points.

There are two types of project monitoring evaluations, implementation and effectiveness. Implementation monitoring should ensure that the project was completed as designed (i.e. quality control), while effectiveness monitoring should ensure the project meets the intended objectives related to target species. General criteria for deciding which projects are monitored for their effectiveness include: 1) available funding for monitoring, 2) the amount of money spent of projects with the most expensive projects receiving a higher priority for monitoring, 3) demonstration value of the project, 4) categories of projects prone to setbacks, 5) the importance of target fish species to be enhanced/restored, and 6) feasibility. Monitoring periods should involve the recovery time necessary to ascertain whether a project meets its objectives, and extend through the life of the project as identified in cooperative agreements.

Generic steps in developing and designing projects and conducting pre-project effectiveness monitoring include: 1) collecting baseline habitat and fisheries data, 2) developing project objectives relating limiting factors to target fish populations, and 3) identifying how the project will alter or expand habitat(s) limiting target population(s). Identifying monitoring protocols for effectiveness should then consider the category of restoration project needed to meet objectives and the type of monitoring appropriate to the category. Examples of seven restoration categories and the types of monitoring appropriate to each category are described below in general terms.

\section{Restoration Category}


Streamflow enhancement: Pre-project evaluations involve assessing critical flow periods for target fish species. Methods used include water withdrawals using staff gauges, flow measurements, instream flow models, USGS gauging stations and photo points. Quantifying fish populations often includes 1) age/length structure, population densities and angler surveys within the stream and (or) in a control stream of more natural flow, and 2) assessing the season use of the stream by target species. Post-project monitoring should assess how streamflow and fish populations have changed in manner consistent with pre-project evaluation.

Spawning enhancement (non-flow limited): The basic question related to spawning enhancement is if the target fish population is below carrying capacity, and if the lack of recruitment relates to insufficient spawning sites or other factors such as predation, juvenile winter survival or connectivity for returning adults. Pre-project evaluations may include: 1) identifying the traditional and current use of spawning in the project area using redd counts or historical records, and/or 2) identifying insufficient recruitment by evaluation age/length structure using electrofishing, fry trapping or seining. Post-project evaluations would also involve redd counts and the appropriate quantification of recruitment.

Instream wood placement: The basic questions here are 1) has the loss of wood reduced the carrying capacity of a stream, or 2) does wood placement offer a target species improved habitat conditions on a seasonal basis. Assessing the need for wood placements involves reference reach surveys involving 1) natural pool spacing, 2) habitat surveys, 3) assessments of long-term large wood recruitment within a context of land management, and 4) fish population surveys. Before and after and reference reach surveys are appropriate methods of monitoring.

Streambank stabilization, channel instability and channel reconstruction: Pre-project evaluations should assess whether sediment, channel instability or some other aspect of a streams geomorphic condition is a legitimate limiting factor affecting an aquatic population or water quality. Related questions involve whether the stream left untreated, will correct itself under reasonable time with alternative land management (e.g. vegetative means). Channel instability, methods of stabilization and new channel design can be quantified using channel classification, reference reaches and regional curve geometry relationships for streams of similar morphology and channel succession. Preproject information of this type involves aerial photos, erosion analysis, longitudinal surveys and bankfull cross-sections and pebble counts or McNeil core surveys. Methods of geomorphic assessment, validation and prediction are well established (Rosgen 1996). Geomorphic assessments of altered streams usually require a review of causal factors related to historic and existing riparian land management. Pre-and post project and/or treatment control fisheries, habitat and substrate surveys are appropriate monitoring methods depending on nature of the specific problem.

Fish Passage enhancement: Improved fish passage relate to the movements and migrations of target species, the potential for additional downstream recruitment, and whether the native fish population upstream of an existing barrier that will be harmed by 
the removal of a barrier. Pre-project monitoring at barriers should first involve species composition, genetic status of native species and potential for disease transmission. If barrier removal is deemed appropriate, fish population monitoring using redd counts, estimates of population size, fry out-migration are likely appropriate for both pre-and post project monitoring.

Riparian grazing improvements: Excessive livestock access to riparian areas is among the most pervasive habitat-related impairments in the Blackfoot Watershed. Restoration projects involving grazing are also highly subject to setbacks due largely to insufficient monitoring. The results of poor livestock management include channel widening, weakened stream banks, excessive streambank erosion, loss of streambank vegetation and elevated sediment and water temperatures, all of which can have serious consequences to fish populations. The initial question is whether livestock in the riparian area is limiting aquatic populations, and if so how, and what alternatives can improve the riparian area to a condition that corrects limiting factors associated with degradation. Depending on the specific nature of the site and problem(s), pre-and post project evaluations should always include photo points and, if necessary, assessments of 1) geomorphic state, 2) percent hoof-shear, 3) composition, density and vigor of plant species the community, 4) percent shrub utilization, 5) stubble height of indicator plant species, 7) fish populations, 8) water temperature, and 9) measurements of water quality. Monitoring "targets" should also be incorporated into grazing plans. Grazing targets, usually based on shrub utilization and hoof-shear, identify the point above which riparian grazing of the immediate stream banks is deemed excessive. At target thresholds, livestock management measures should be undertaken in order to prevent excessive stream damage. Targets for acceptable stream bank trampling generally range between 10 and 30 percent.

Fish screens on irrigation diversions: Fish screens should be used in native fish migration corridors, where downstream fish populations are limited by insufficient recruitment and if irrigation-ditch losses represent a significant portion of the existing reproduction. Pre-and post project evaluations may include telemetry studies, population estimates, ditches trapping or some measure of recruitment.

\section{Types of Monitoring}

For each restoration category, several types of monitoring can be used to evaluate a project for effectiveness. Specific monitoring methods are variable and relate to the specific nature of the problem and restoration objective(s). Outlined below are examples of the types and methods of monitoring (Table 3), and how restoration categories and monitoring should be conducted (Table 4).

Table 3. Type and methods of monitoring

- Geomorphic condition of channel - see Rosgen 1996 GM

- Substrate - McNeal cores, pebble counts ST

- physical habitat - variable methods PH

- instream flow- synoptic flows, staffs and rating tables, aquarods,

- gauging stations IF

- water temperature - instantaneous or continuous recorders WT 
- water quality - turbidity, sediment, metals, nutrients WQ

- macro-invertebrates - variable methods MI

- vegetation - riparian health, "greenline", stubble height, shrub utilization V

- streambank condition (grazing-related) - percent hoof-shear SC

- fish populations - trapping, electrofishing, redd counts, genetic tests, angler surveys

FP

Table 4. Restoration categories, the type of monitoring appropriate to the category and methods of conducting restoration monitoring on fisheries projects.

$\underline{\text { Restoration Category }}$

Improve spawning habitat

Improve rearing conditions

Restore pool quality or quantity

Restore migration corridors

Enhance instream flow

Improve streambank stability

Restore vegetative health (grazing related)

Eliminate fish losses to ditches

Improve water quality

$* \mathrm{~T}=$ treatment/control, $\mathrm{B}=$ before/after, $\mathrm{TB}=$ either or both

In summary, identifying monitoring protocols for effectiveness should begin with: 1) clearly stated objectives based on limiting factors, 2) an identified project category to meet fisheries objectives, 3) identified the type of monitoring appropriate to the category, and 4) ensure that monitoring at all levels be conducted in a scientifically appropriate manner. Monitoring is paramount to measuring success (and failures) of restoration methods and should be implemented at programmatic level for the outcomes of this strategy to be confirmed. 


\section{APPENDICES}

Exhibit A: Guiding documents for the Restoration Action Plan

Exhibit B: Prioritization matrix

Exhibit C: List of impairments

Exhibit D: Tables of restoration priority groups: 1) total restoration priority, 2) biological priority, 3) native species priority, 4) dewatered stream by biological priority, and 5) the FWP dewatered stream list.

\section{Appendix A: Guiding documents}

\section{Recovery Documents}

Montana Bull trout Scientific Group. 1995. Blackfoot River drainage bull trout status report. Unpublished report prepared for the Montana Bull Trout Restoration Team. Montana Fish, Wildlife and Parks.

Montana Bull Trout Restoration Team. 1998. The relationship between land management activities and habitat requirements of bull trout. The Montana Bull Trout Scientific Group, c/o Montana Fish, Wildlife and Parks, Helena, Montana.

Montana Bull Trout Restoration Team. 2000. Restoration plan for bull trout in the Clark Fork River Basin and Kootenai River Basin Montana. A report to Governor Marc Racicot c/o Montana Fish, Wildlife and Parks, Helena, Montana.

Pierce, R., C. Podner and J. McFee. 2002b. A hierarchical strategy for prioritizing the restoration of 83 impaired tributaries of the Big Blackfoot River. Montana Fish, Wildlife and Parks, Missoula, Montana.

Region 2 Native Salmonid Management Guidelines, Montana Fish, Wildlife and Parks, Missoula.

Shepard, B. B., B. E May and W. Urie. 2003. Status of westslope cutthroat trout (Oncorhynchus clarki. lewisi) in the United States: 2002. A report to the Westslope Cutthroat Interagency Conservation Team.

USFWS, 2002. Draft recovery plan for the bull trout and proposed critical habitat. U. S. Fish and Wildlife Service, Portland, Oregon.

\section{Research Documents}

McIntyre, J. D., and B. E. Reiman, 1995. Westslope WSCT. Pages 1-15 in M. K. Young, editor. Conservation assessment for inland WSCT. U. S. Forest Service General Technical Report. RM-256.

Reiman, B. E. and J. D. McIntyre. 1993. Demographic and habitat requirements for conservation of bull trout. USDA Forest Service, Intermountain Research Station GTR INT-302.

Schmetterling, D. A. 2001. Seasonal movements of fluvial westslope cutthroat trout in the Blackfoot River drainage, Montana. North American Journal of Fisheries Management 21: 507-520.

Shepard, B. B., M. Taper, R. G. White and S. C. Ireland. 1998. Influence of abiotic and biotic factors on abundance of stream-resident westslope cutthroat trout Onchorynchus clarki lewisi in Montana Streams. Final Report to: USDA, Forest Service, Rocky Mountain Research Station, Boise, ID. 
Smith, L. 1998. Study on the distribution and abundance of Tubifex tubifex within Cottonwood Creek in the Blackfoot drainage. Masters Thesis, University of Montana, Missoula, Montana.

Swanberg, T. R. 1997. Movements of and habitat use by fluvial bull trout in Blackfoot River. Transactions of the American Fisheries Society 126:735-746.

Pierce et al. 2004. Spawning migrations and habitat use by fluvial westslope cutthroat and bull trout in the upper Blackfoot Watershed, p. 63-78, in The Big Blackfoot River Restoration Progress Report for 2002 and 2003. Montana Fish, Wildlife and Parks, Missoula, Montana.

Restoration Monitoring Documents

Fitzgerald, G. 1996. Inventory and analysis of riparian vegetation along Nevada Creeks, Report prepared for the North Powell Conservation District, and the University of Montana. Missoula.

Fitzgerald, G. 1996. Inventory and analysis of riparian vegetation along Nevada Creek and Monture Creeks, MS Thesis, University of Montana, Missoula.

Koopal, M. 1998. Stream habitat analysis of selected tributaries of the Blackfoot River. Report prepared for the Montana, Fish, Wildlife and Parks, Missoula.

Ingman, G, L., M.A. Kerr and D.L. McGuire 1990. Water quality investigations in the Blackfoot River drainage, Montana. Department of Health and Environmental Services, Helena, Montana.

Marler, M. 1997. Riparian health and inventory of the Blackfoot River between Nevada Creek and the North Fork Confluence: A GIS mapping project. Report to Montana Fish, Wildlife and Parks, Missoula, MT.

Marler, M. J., and D. A. Schmetterling. 1999. Riparian health and inventory of selected reaches of the Blackfoot River. Final report to the BLM, Garnet Resource Area and Montana Fish, Wildlife and Parks, Missoula.

Peters, D. and R. Spoon. 1989. Preliminary fisheries inventory of the Big Blackfoot River. Montana Department of Fish, Wildlife and Parks, Missoula, Montana.

Peters, D. 1990. Inventory of fishery resources in the Blackfoot River and major tributaries to the Blackfoot River. Montana Department of Fish, Wildlife and Parks, Missoula, Montana.

Pierce R. and D. Peters, 1990. Aquatic investigations in the middle Blackfoot River, Nevada Creek and Nevada Spring Creek corridors. Montana Department of Fish, Wildlife and Parks, Missoula.

Pierce, R, 1991. A stream habitat and fisheries analysis for six tributaries to the Blackfoot River. Montana Department of Fish, Wildlife and Parks, Missoula, Montana.

Pierce, R., D. Peters and T. Swanberg. 1997. Blackfoot River restoration progress report. Montana Fish Wildlife and Parks, Missoula, Montana.

Pierce, R., and D. Schmetterling. 1999. Blackfoot River restoration project monitoring and progress report 1997-1998. Montana Fish, Wildlife and Parks, Missoula, Montana.

Pierce, R. and C. Podner. 2000. Blackfoot River fisheries inventory, monitoring and restoration report. Montana Fish, Wildlife and Parks, Missoula, Montana. 
Pierce, R. and C. Podner and J. McFee. 2001. Blackfoot River fisheries inventory, monitoring and restoration report. Montana Fish, Wildlife and Parks, Missoula, Montana.

Pierce, R., C. Podner and J. McFee. 2002. The Blackfoot River fisheries inventory, restoration and monitoring progress report for 2001. Montana Fish, Wildlife and Parks, Missoula, Montana.

Pierce, R., R. Anderson and C. Podner. 2004. The Big Blackfoot River Restoration Progress Report for 2002 and 2003. Montana Fish, Wildlife and Parks, Missoula, Montana.

Schmetterling D. A, and R. W. Pierce. 1999. Success of instream habitat structures after a 50-year flood in Gold Creek, Montana. Restoration Ecology 7(4), pp. 369-375.

USGS 2004. Gauging stations $1234000,12335100,12337800,12338300,12335500$, provisional unpublished data. 


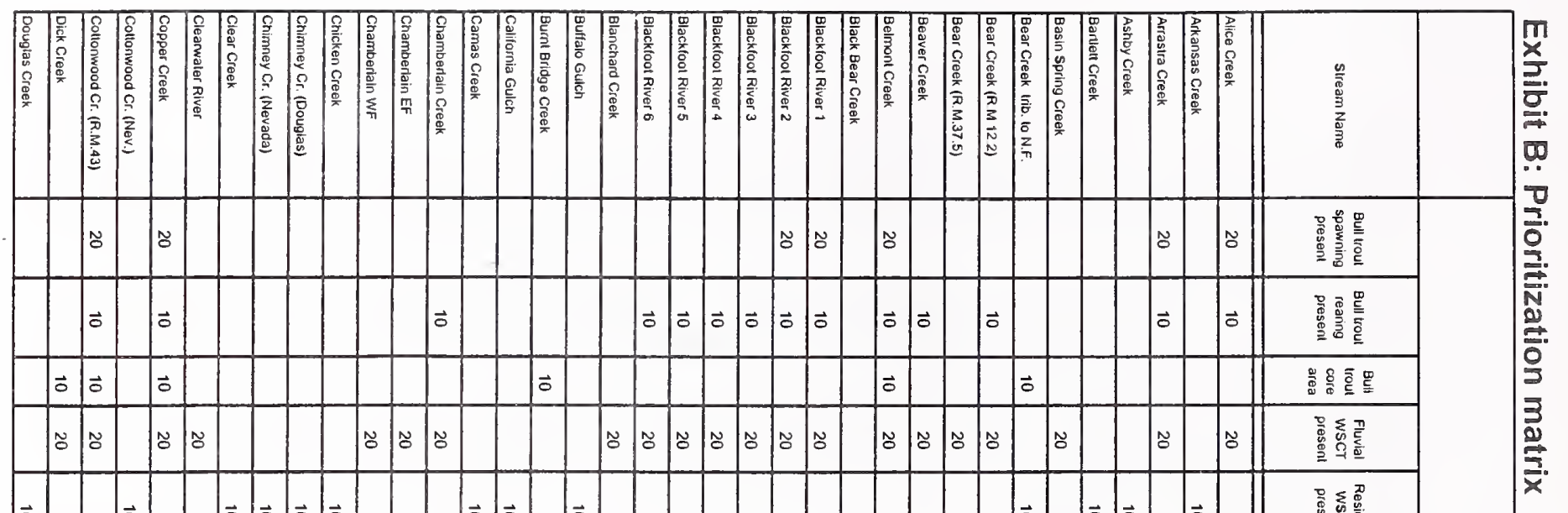

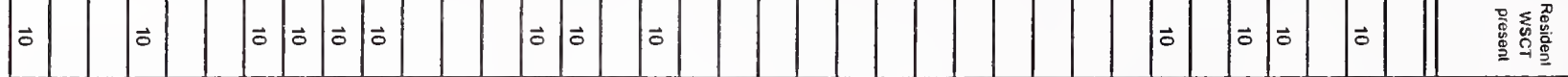

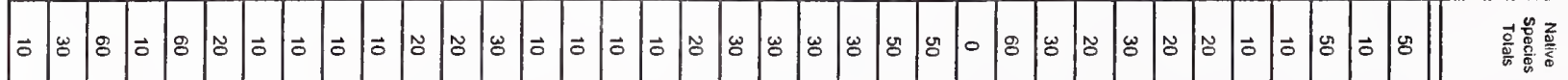

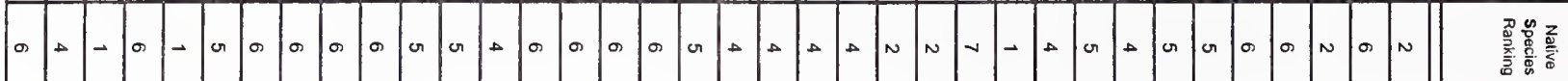

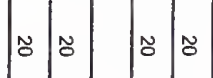

$\approx$

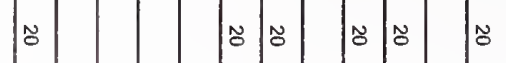

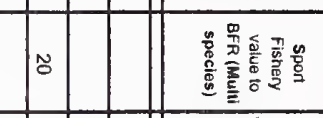

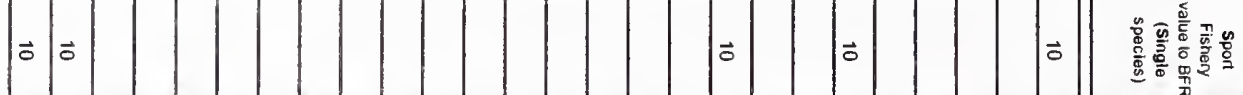

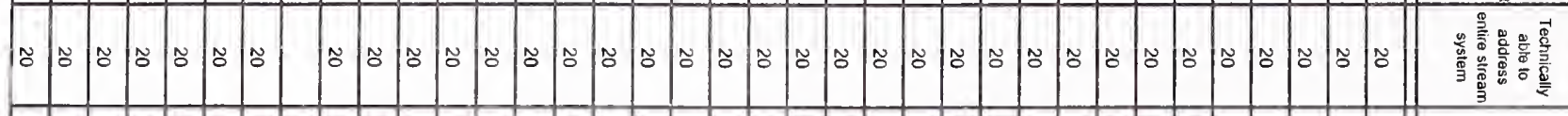

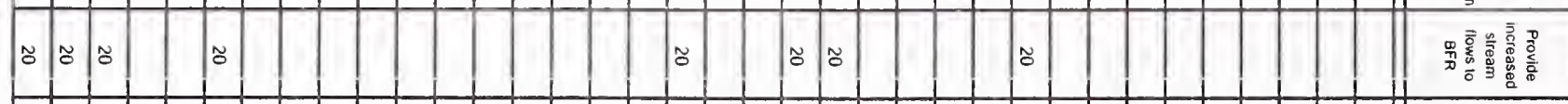

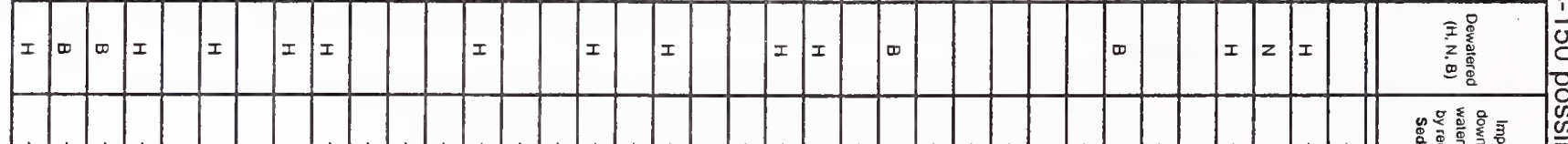

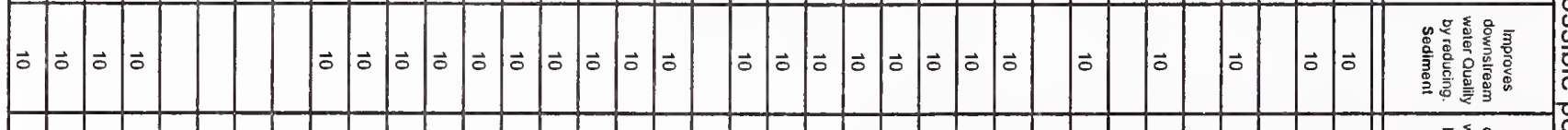

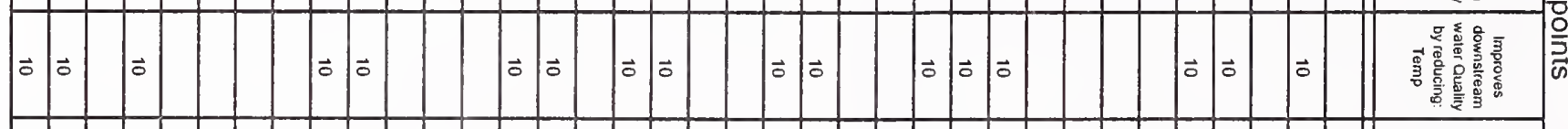

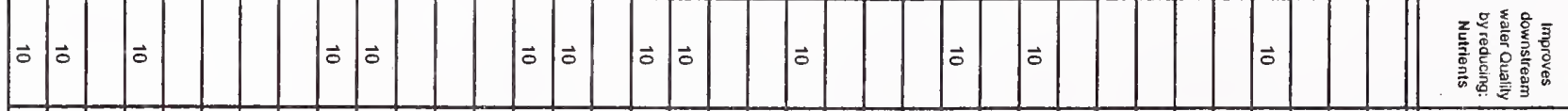

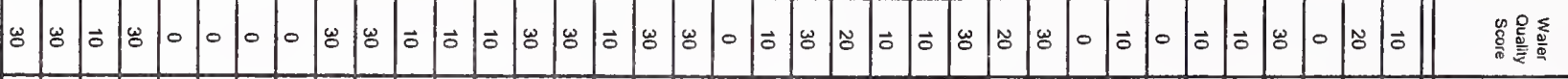

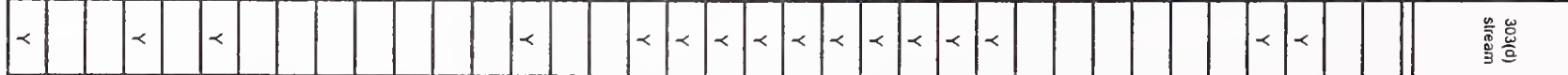

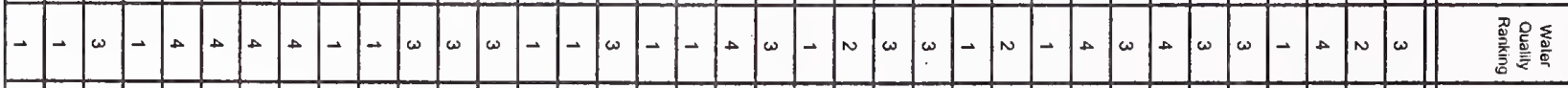

\&

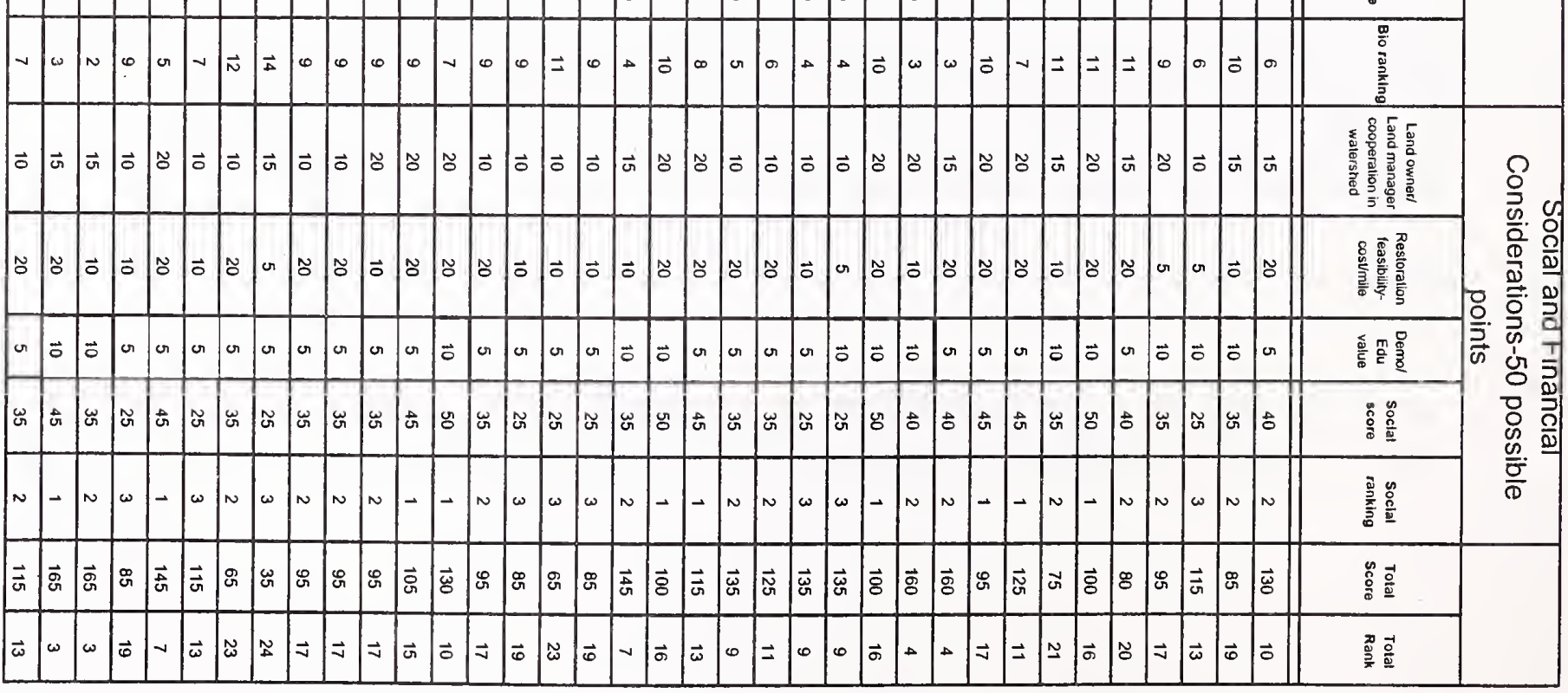




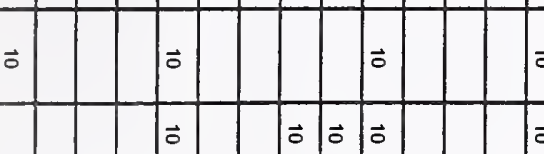

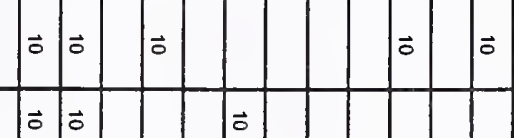

$\approx$

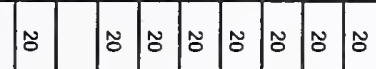

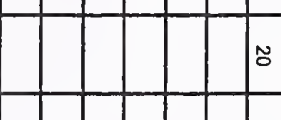

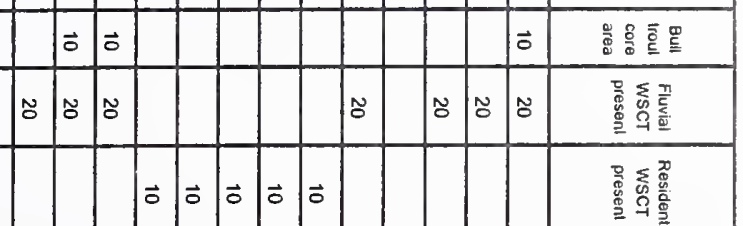

\begin{tabular}{ll|l|l|l|l|l|l}
\hline & $\overrightarrow{0}$ & $\overrightarrow{0}$ & $\overrightarrow{0}$ & $\overrightarrow{0}$ & $\overrightarrow{0}$ \\
\hline
\end{tabular}

$\begin{array}{lllllllllllllll} & \overrightarrow{0} & \overrightarrow{0} & \overrightarrow{0} & \overrightarrow{0} & \overrightarrow{0}\end{array}$

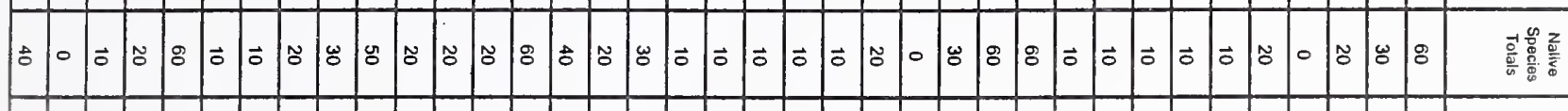

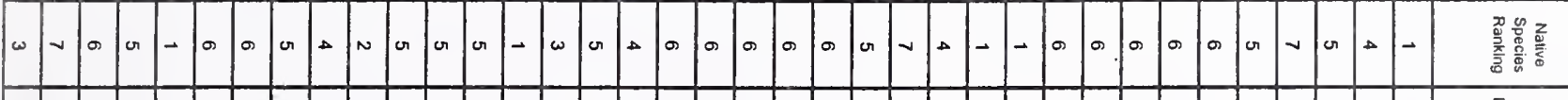

$\approx$

$\approx \sim ⿻ \sim 乛$

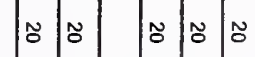

$\because: 8$ :

$\overrightarrow{0} \quad \overrightarrow{0} \quad \overrightarrow{0} \quad \overrightarrow{0} \quad \overrightarrow{0} \quad \overrightarrow{0}$

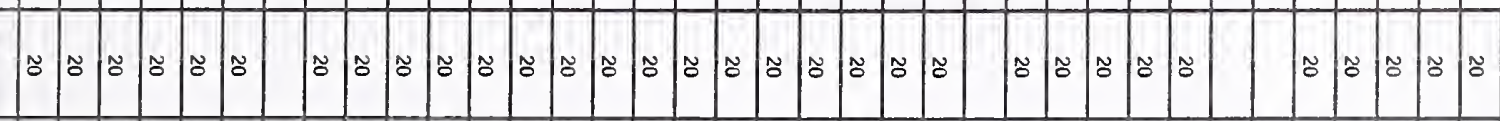
$\approx$ $\approx$ a

\begin{tabular}{l|l|l}
\hline$z$ & $I$
\end{tabular}

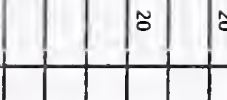

I

$\begin{array}{lllllllllllllll}\overrightarrow{0} & \overrightarrow{0} & \overrightarrow{0} & \overrightarrow{0} & \overrightarrow{0} & \overrightarrow{0} & \overrightarrow{0} & \overrightarrow{0}\end{array}$

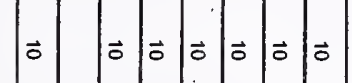
$\approx$

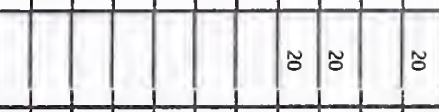

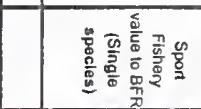

\begin{tabular}{|l|l|l|l|l|l|l|l|l|l|l}
\hline $\overrightarrow{0}$ & $\overrightarrow{0}$ & $\overrightarrow{0}$ & & $\overrightarrow{0}$ & & $\overrightarrow{0}$ \\
\hline
\end{tabular}

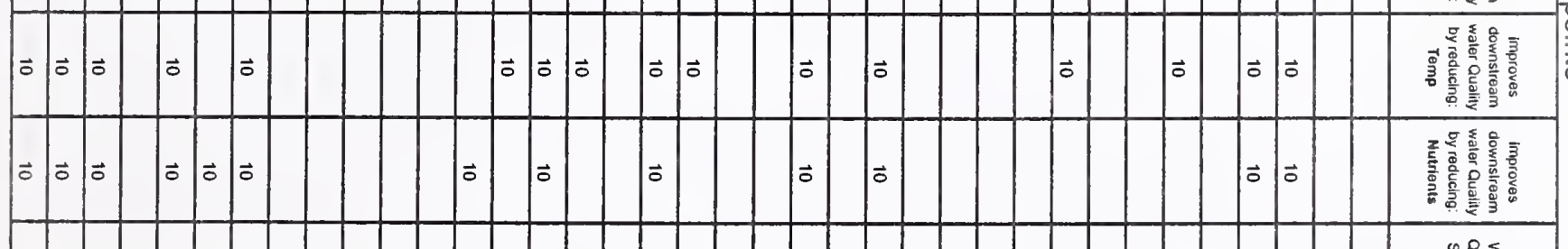

$\infty$

$+1$

I II II $I \pm \infty$

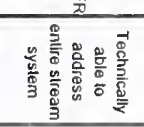

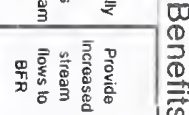

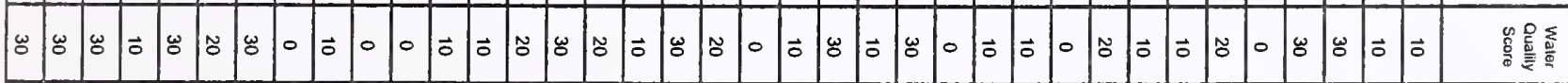

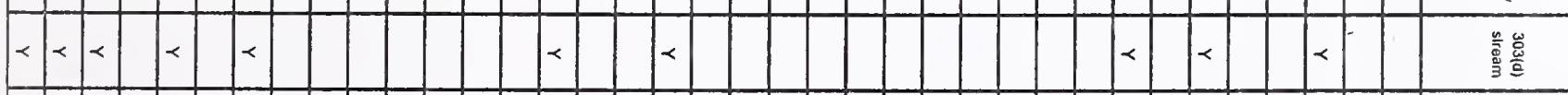

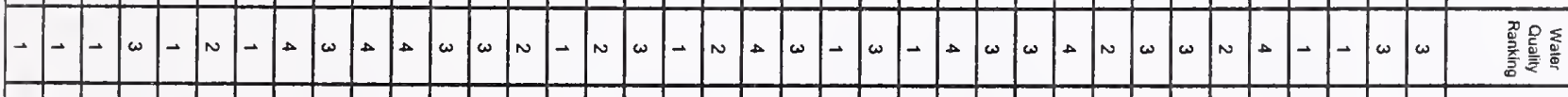

O

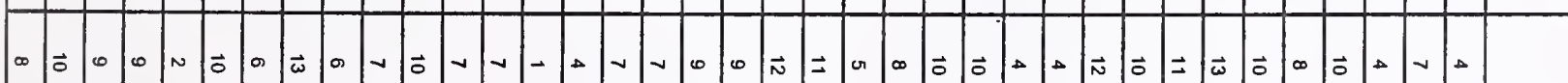

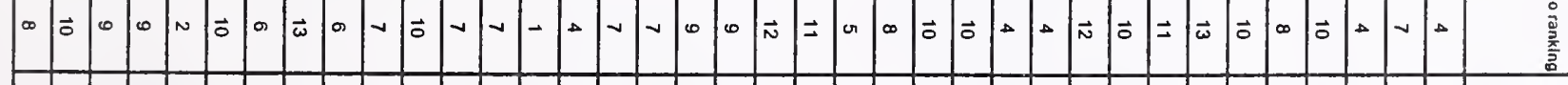

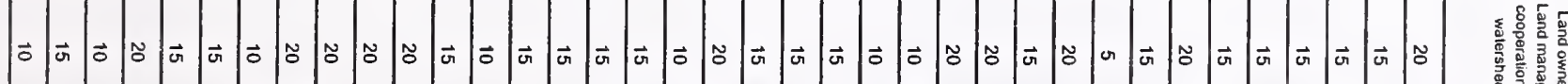

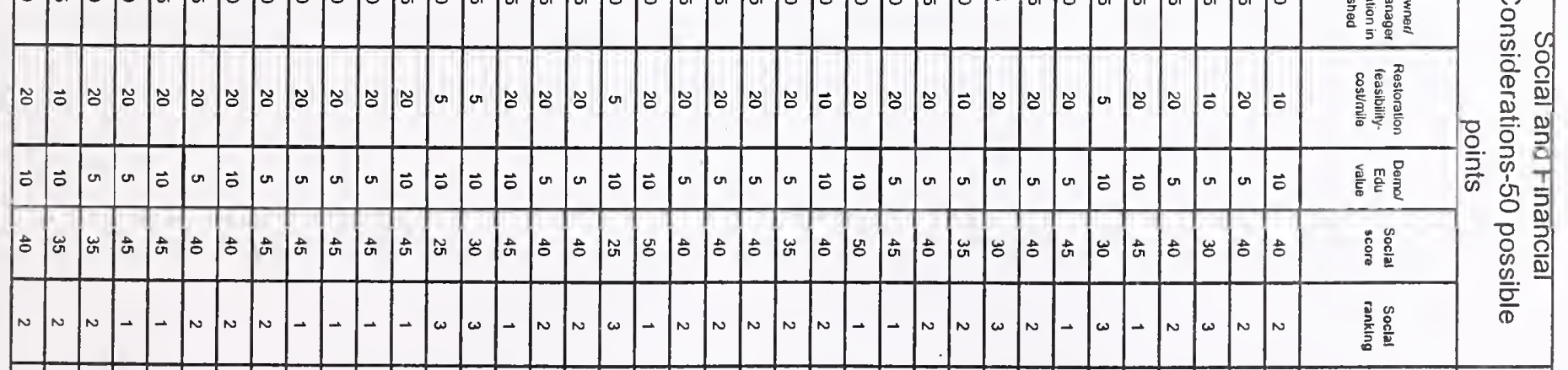

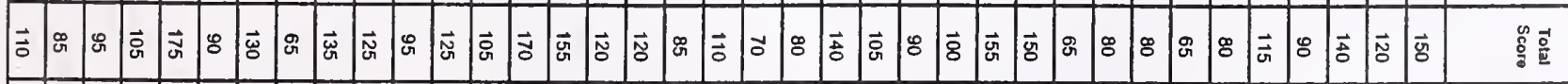

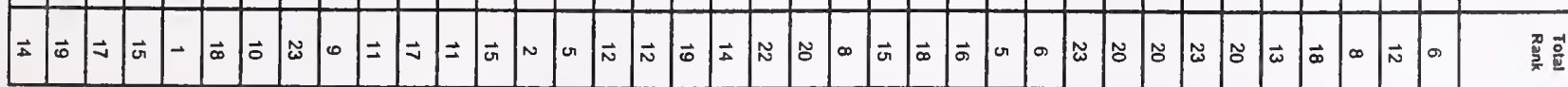




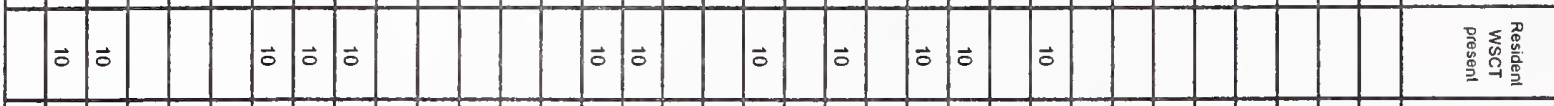

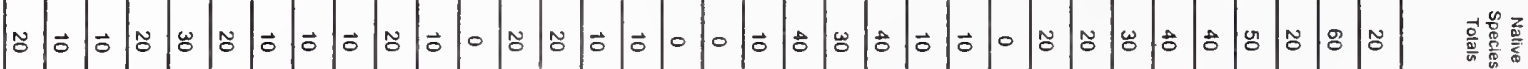

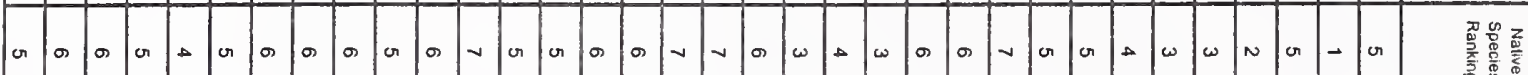

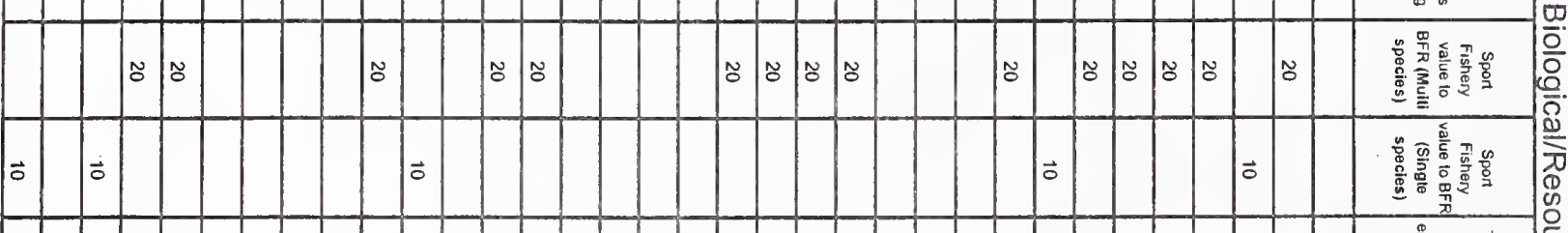

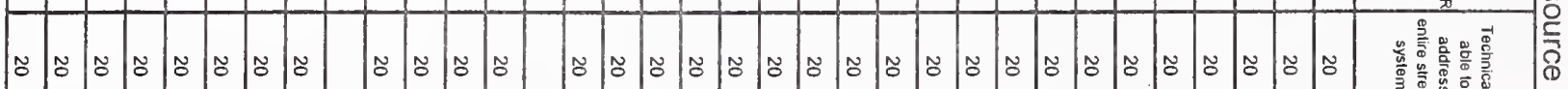

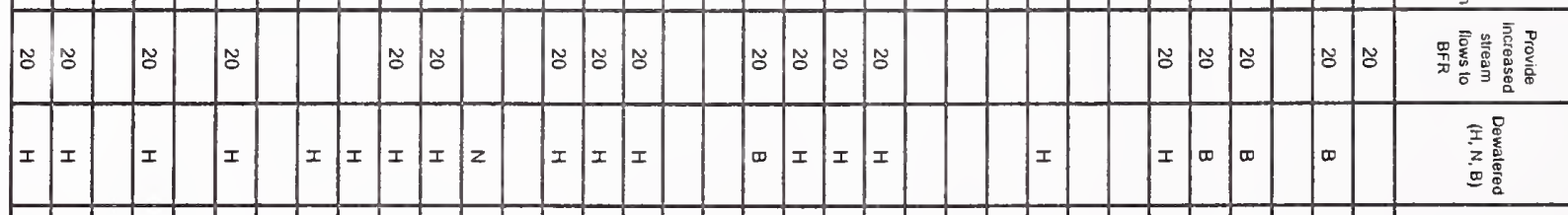

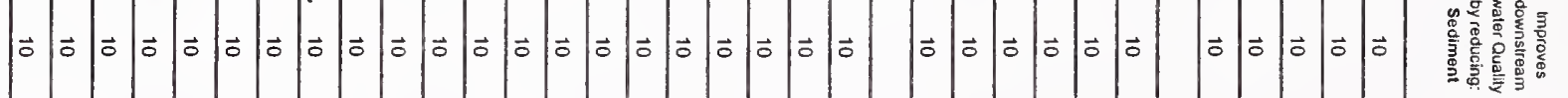

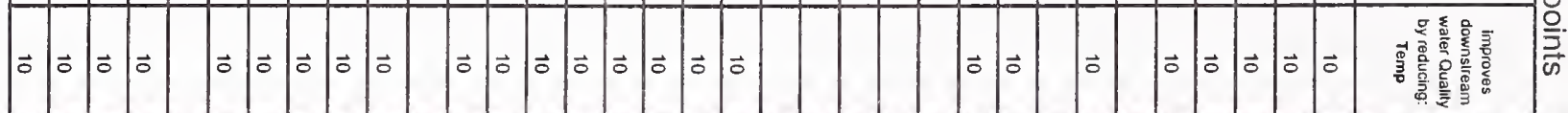

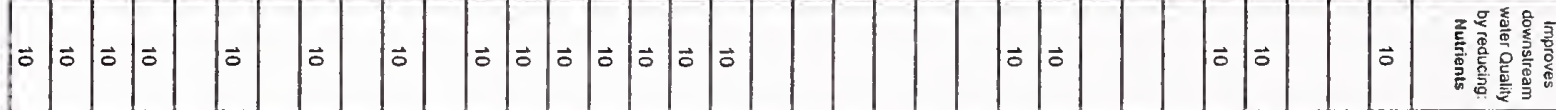

|

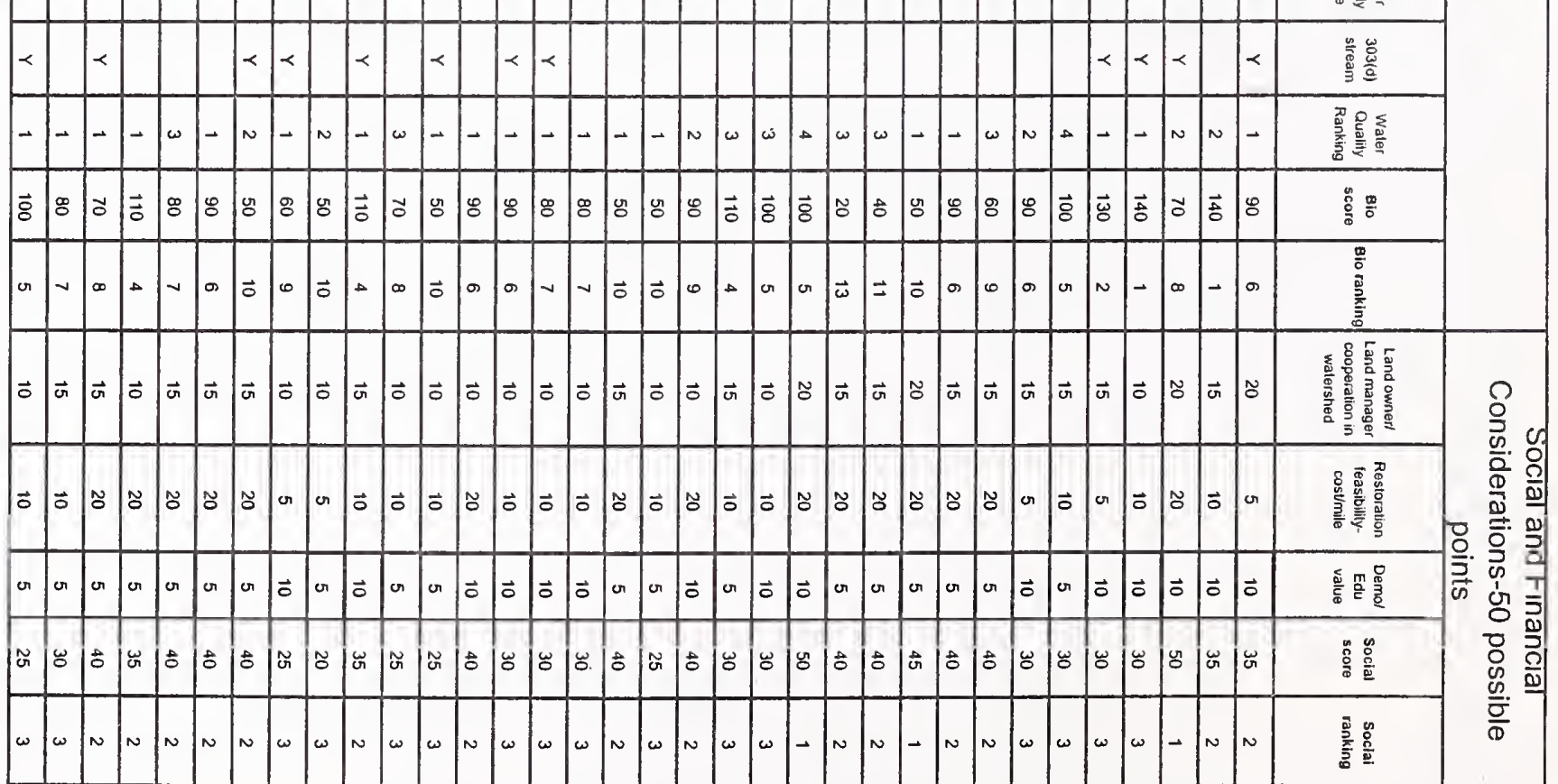

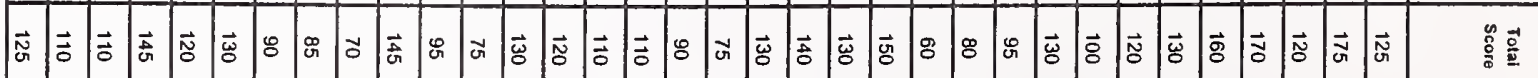

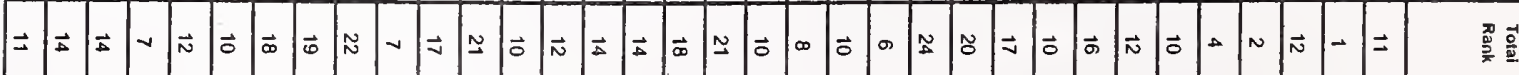




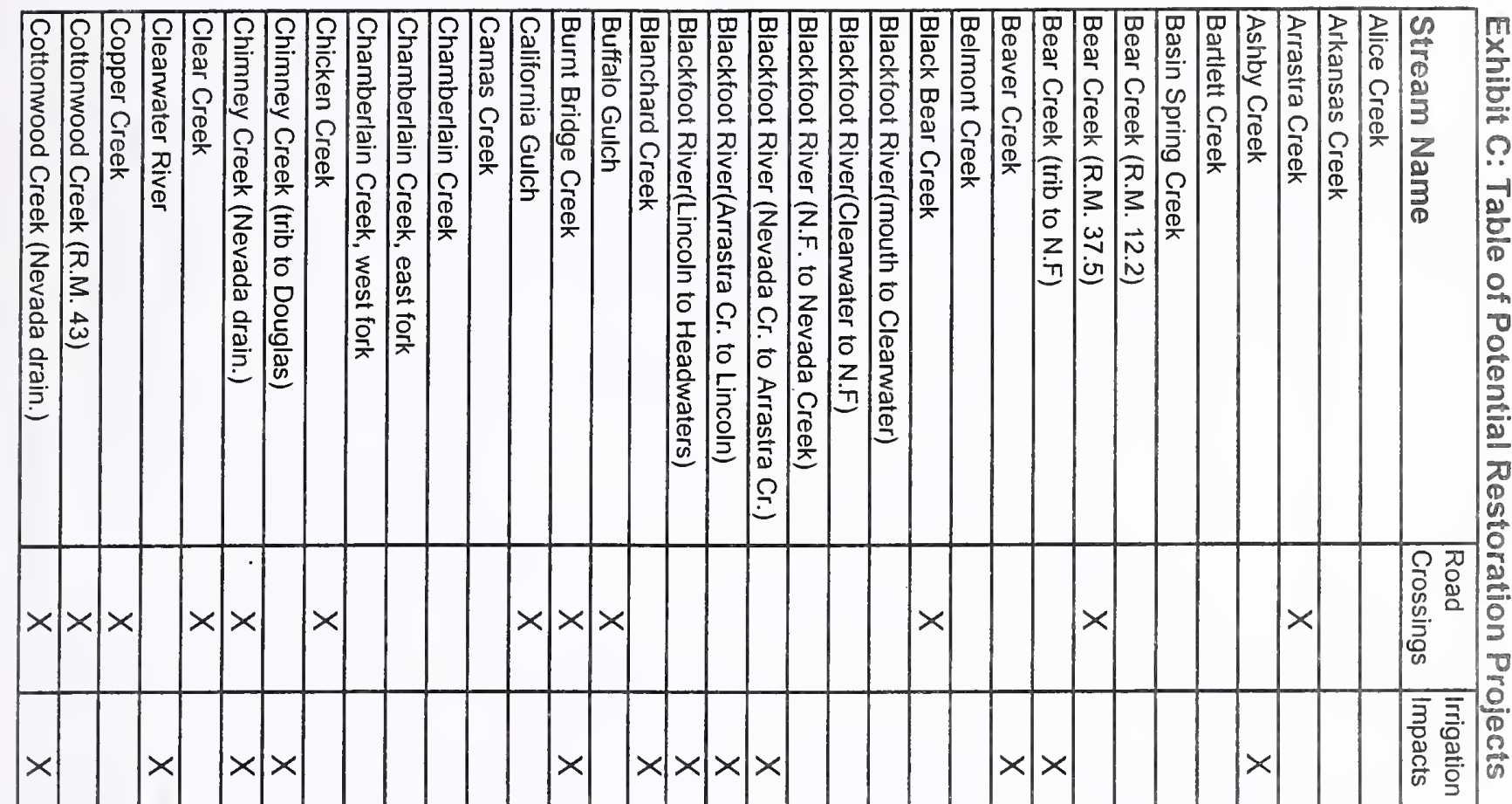

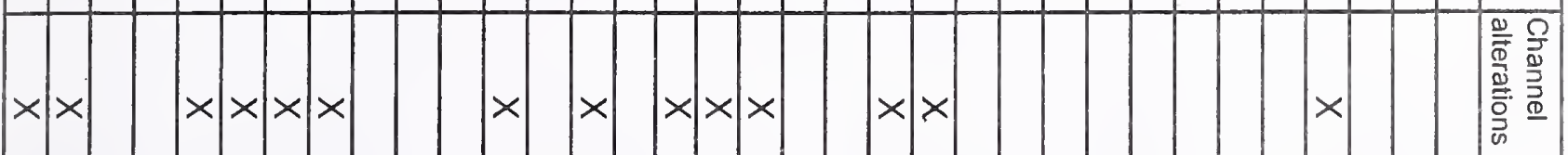

$x \times \quad \times x \quad \times x|x| x \times x \mid x$

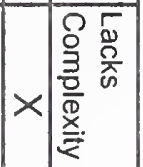

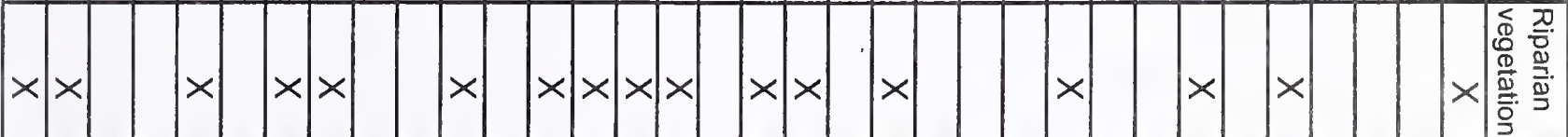

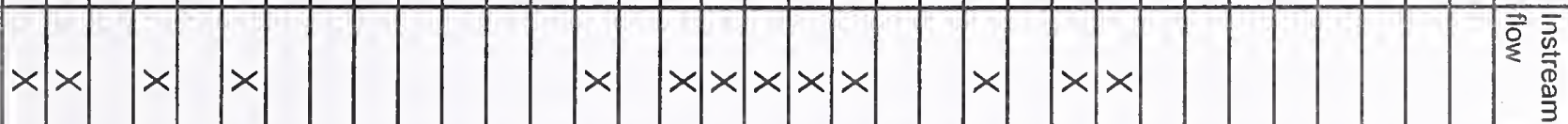

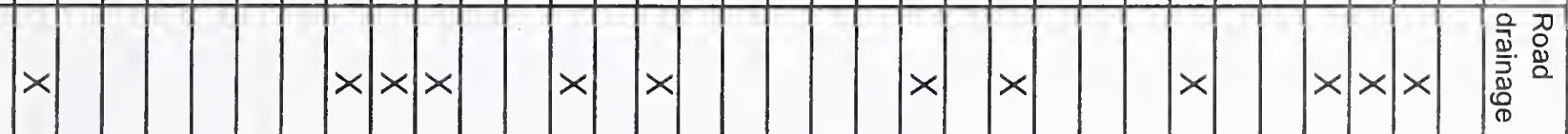

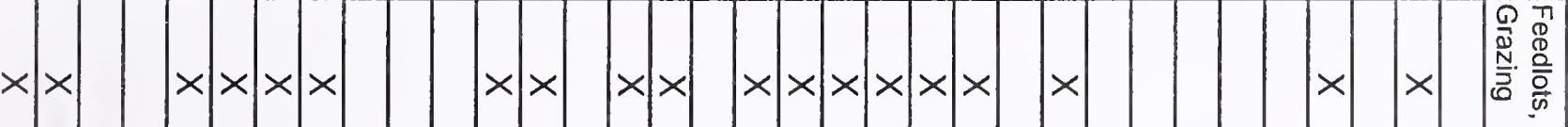

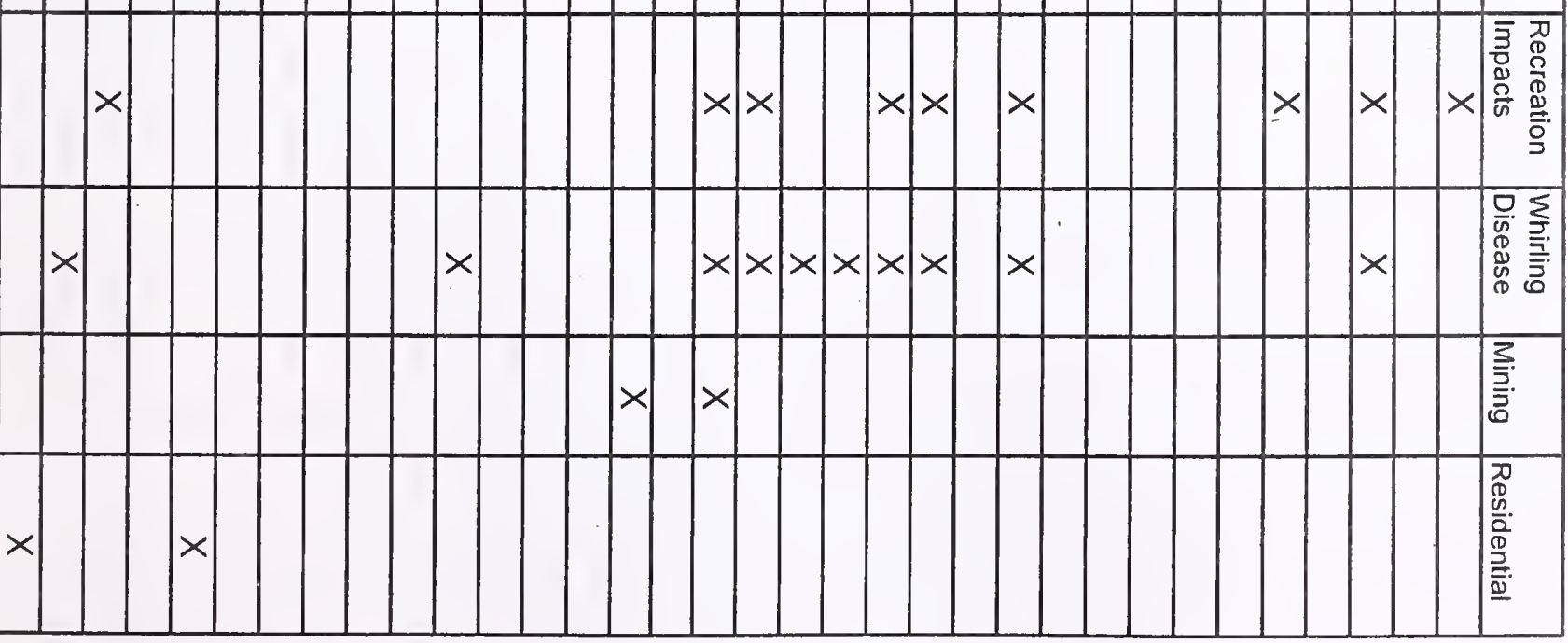




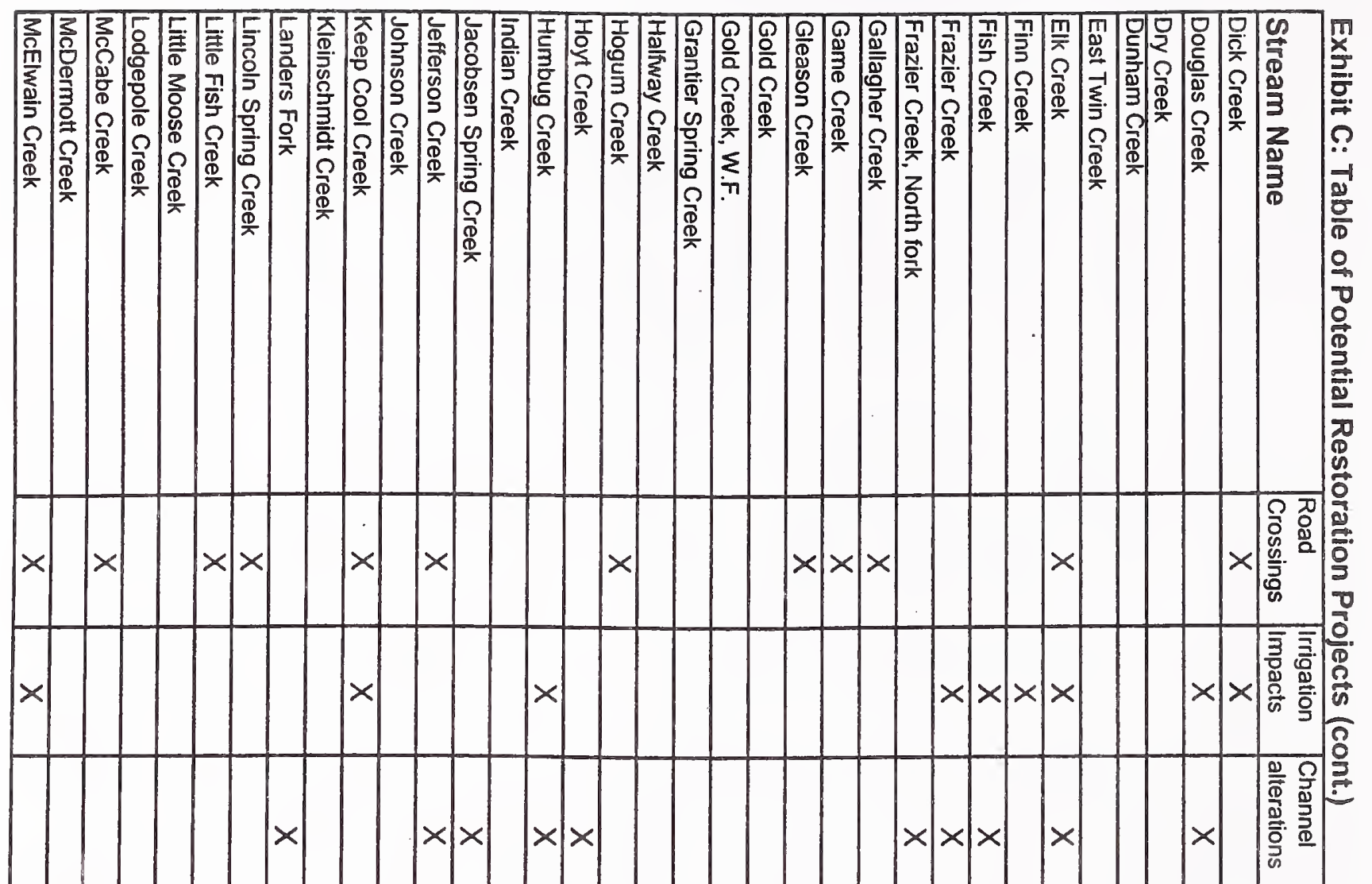

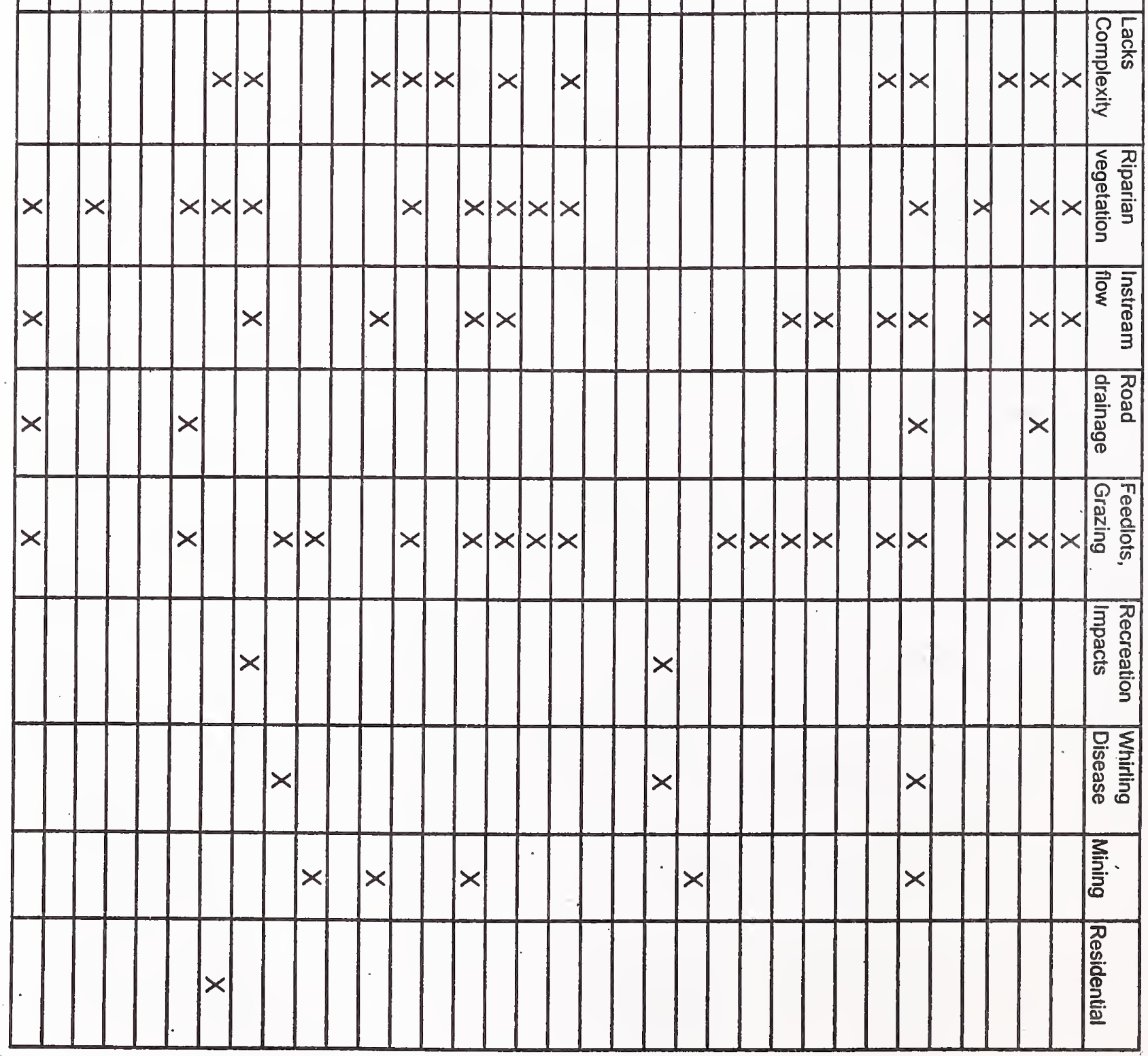




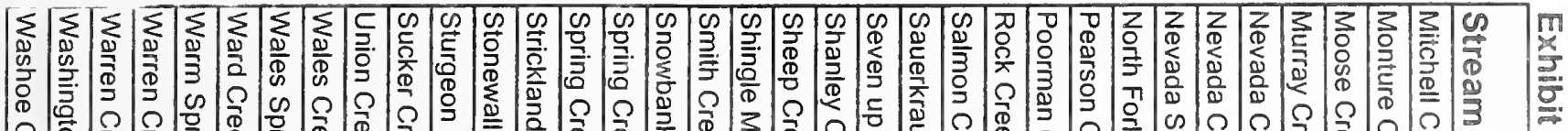

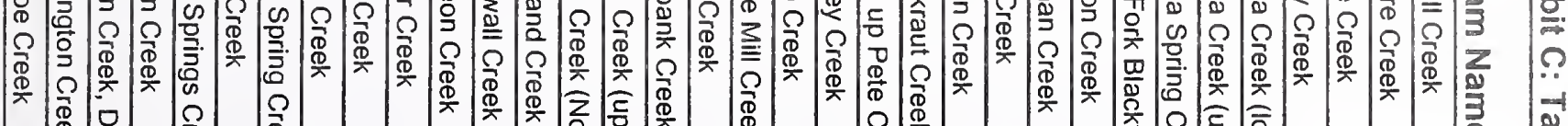

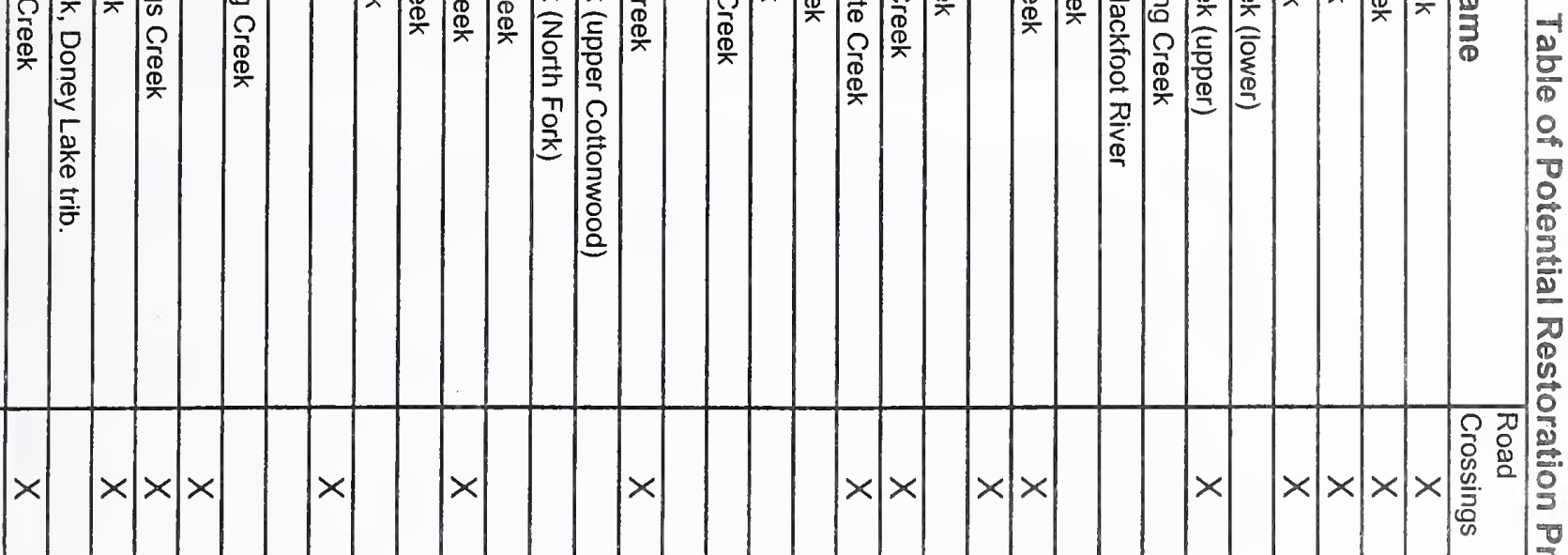

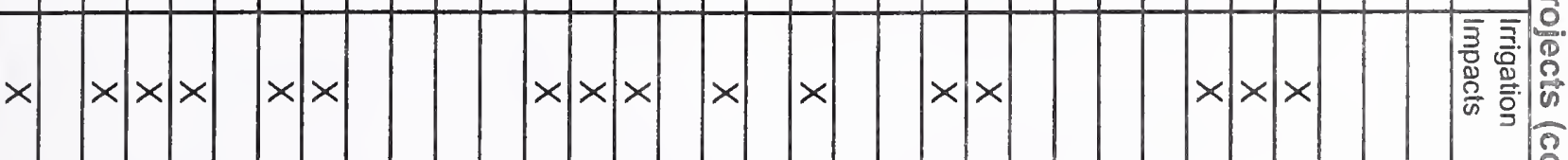

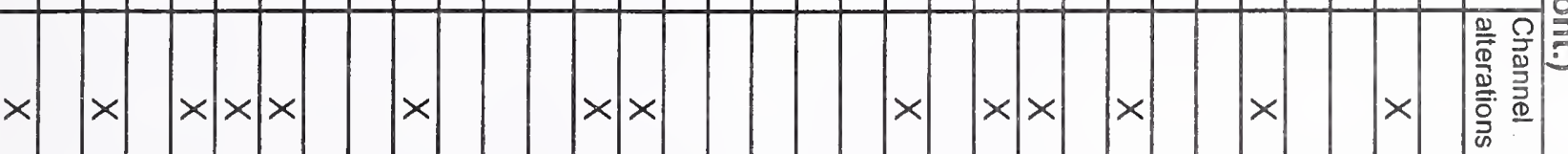

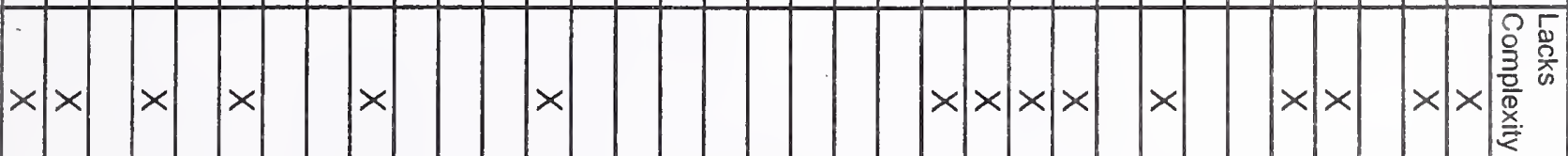

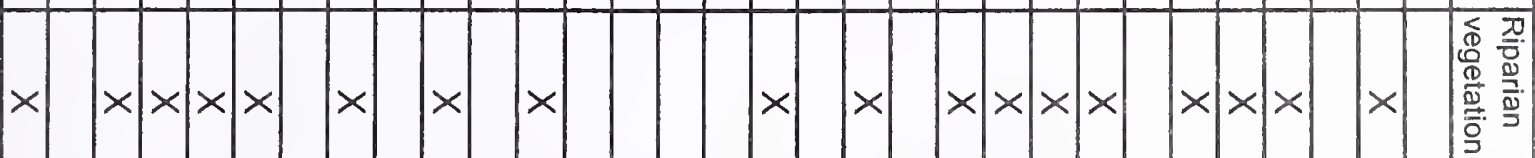

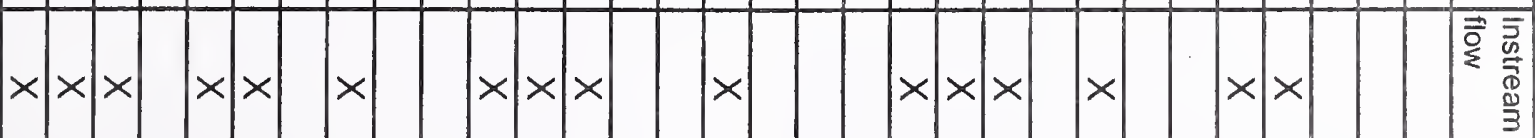

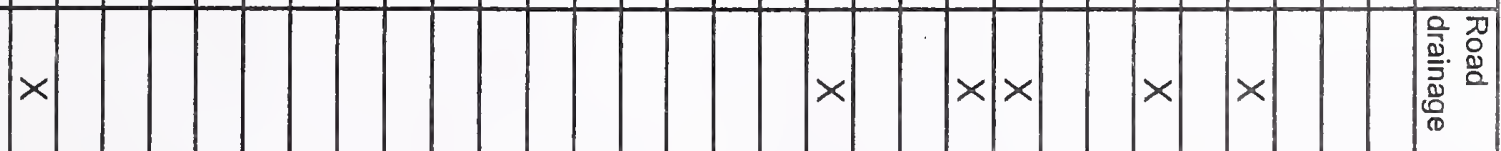

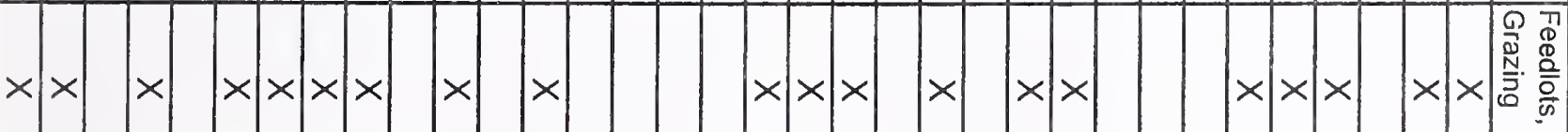

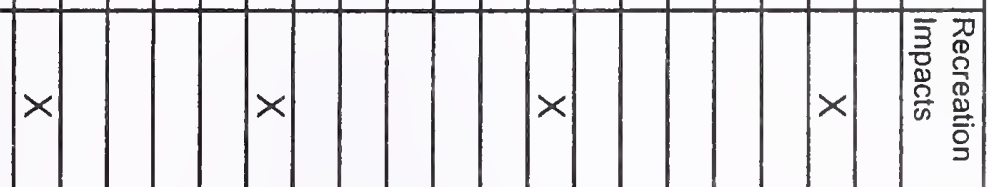

$\times$

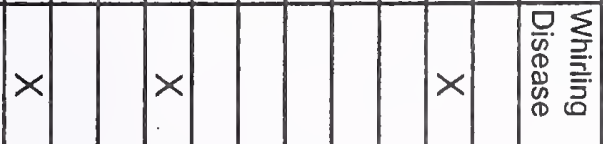

$\times$

$\times$

$\times x$

$\times \times \times$

$\times$

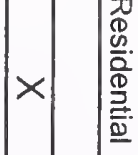




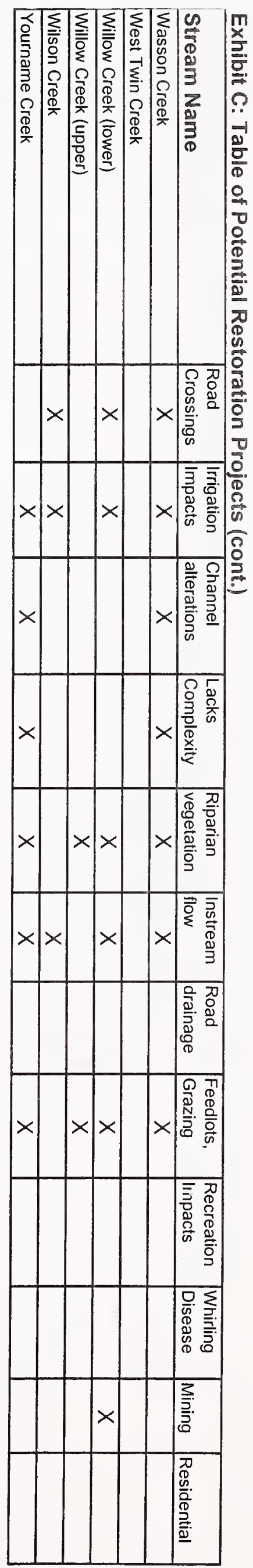


Exhibit D: Table 7. Water bodies sorted by total restoration priority.

\begin{tabular}{|c|c|c|c|c|c|c|c|c|}
\hline Stream Name & $\begin{array}{l}\text { Total } \\
\text { Rank } \\
\end{array}$ & Priority & Stream Name & $\begin{array}{l}\text { Total } \\
\text { Rank } \\
\end{array}$ & Priority & Stream Name & $\begin{array}{l}\text { Total } \\
\text { Rank } \\
\end{array}$ & Priority \\
\hline Monture Creek & 1 & High & West Twin Creek & 12 & Moderate & Humbug Creek & 20 & Low \\
\hline N.F. Blackfoot R. & 1 & High & Arrastra Creek & 13 & Moderate & Shingle Mill Creek & 20 & Low \\
\hline Landers Fork & 2 & High & Blackfoot River 5 & 13 & Moderate & Bear Creek trib. to N.F. & 21 & Low \\
\hline Poorman Creek & 2 & High & Clearwater River & 13 & Moderate & Strickland Creek & 21 & Low \\
\hline Cottonwood Cr. (R.M.43) & 3 & High & Douglas Creek & 13 & Moderate & Ward Creek & 21 & Low \\
\hline Dick Creek & 3 & High & Fish Creek & 13 & Moderate & Indian Creek & 22 & Low \\
\hline Beaver Creek & 4 & High & Lincoln Spring Cr. & 13 & Moderate & Warren Creek,Doney Lake tr & 22 & Low \\
\hline Belmont Creek & 4 & High & Jacobsen Spring Creek & 14 & Moderate & Burnt Bridge Creek & 23 & Low \\
\hline Rock Creek & 4 & High & Nevada Cr.(upper) & 14 & Moderate & Clear Creek & 23 & Low \\
\hline Gold Creek, W,F & 5 & High & Sucker Creek & 14 & Moderate & Frazier Creek, NF & 23 & Low \\
\hline Kleinschmidt $\mathrm{Cr}$. & 5 & High & Union Creek & 14 & Moderate & Gleason Creek & 23 & Low \\
\hline Dunham Creek & 6 & High & Willow Cr. (upper) & 14 & Moderate & McDermott Creek & 23 & Low \\
\hline Gold Creek & 6 & High & Wilson Creek & 14 & Moderate & Chimney Cr. (Nevada) & 24 & Low \\
\hline Snowbank Creek & 6 & High & Chamberlain EF & 15 & Moderate & Smith Creek & 24 & Low \\
\hline Blanchard Creek & 7 & High & Hogum Creek & 15 & Moderate & & & \\
\hline Copper Creek & 7 & High & Moose Creek & 15 & Moderate & & & \\
\hline Warren Creek & 7 & High & Basin Spring Creek & 16 & Moderate & & & \\
\hline Willow Cr. (lower) & 7 & High & Black Bear Creek & 16 & Moderate & & & \\
\hline Elk Creek & 8 & High & Blackfoot River 6 & 16 & Moderate & & & \\
\hline Hoyt Creek & 8 & High & Grantier Spring Cr. & 16 & Moderate & & & \\
\hline Spring Creek (N.F.) & 8 & High & Seven up Pete $\mathrm{Cr}$. & 16 & Moderate & & & \\
\hline Blackfoot River 1 & 9 & High & Ashby Creek & 17 & Low & & & \\
\hline Blackfoot River 2 & 9 & High & Bear Creek (R.M.37.5) & 17 & Low & & & \\
\hline Blackfoot River 4 & 9 & High & Camas Creek & 17 & Low & & & \\
\hline McCabe Creek & 9 & High & Chamberlain WF & 17 & Low & & & \\
\hline Alice Creek & 10 & High & Chicken Creek & 17 & Low & & & \\
\hline Chamberlain Creek & 10 & High & Chimney Cr. (Douglas) & 17 & Low & & & \\
\hline McElwain Creek & 10 & High & Little Moose Creek & 17 & Low & & & \\
\hline Salmon Creek & 10 & High & Murray Creek & 17 & Low & & & \\
\hline Shanley Creek & 10 & High & Sheep Creek & 17 & Low & & & \\
\hline Spring Cr.(Cottonwood) & 10 & High & Warm Springs $\mathrm{Cr}$. & 17 & Low & & & \\
\hline Stonewall Creek & 10 & High & Finn Creek & 18 & Low & & & \\
\hline Wales Spring Creek & 10 & High & Halfway Creek & 18 & Low & & & \\
\hline Wasson Creek & 10 & High & Mitchell Creek & 18 & Low & & & \\
\hline Bear Creek (R.M.12.2) & 11 & Moderate & Sturgeon Creek & 18 & Low & & & \\
\hline Blackfoot River 3 & 11 & Moderate & Washoe Creek & 18 & Low & & & \\
\hline Little Fish Creek & 11 & Moderate & Arkansas Creek & 19 & Low & & & \\
\hline Dry Creek & 11 & Moderate & Buffalo Gulch & 19 & Low & & & \\
\hline Lodgepole Creek & 11 & Moderate & California Gulch & 19 & Low & & & \\
\hline Nevada Spring Cr. & 11 & Moderate & Cottonwood $\mathrm{Cr}$. (Nev.) & 19 & Low & & & \\
\hline Yourname Creek & 11 & Moderate & Jefferson Creek & 19 & Low & & & \\
\hline East Twin Creek & 12 & Moderate & Nevada Cr. (lower) & 19 & Low & & & \\
\hline Johnson Creek & 12 & Moderate & Washington Creek & 19 & Low & & & \\
\hline Keep Cool Creek & 12 & Moderate & Bartlett Creek & 20 & Low & & & \\
\hline Pearson Creek & 12 & Moderate & Frazier Creek & 20 & Low & & & \\
\hline Saurekraut Creek & 12 & Moderate & Gallagher Creek & 20 & Low & & & \\
\hline Wales Creek & 12 & Moderate & Game Creek & 20 & Low & & & \\
\hline
\end{tabular}


Exhibit D: Table 8. Water bodies sorted by biological priority.

\begin{tabular}{|c|c|c|c|c|c|c|c|c|}
\hline Stream Name & $\begin{array}{c}\text { Biological } \\
\text { ranking }\end{array}$ & Priority & Stream Name & $\begin{array}{c}\text { Biological } \\
\text { ranking }\end{array}$ & Priority & Stream Name & $\begin{array}{c}\text { Biological } \\
\text { ranking }\end{array}$ & Priority \\
\hline Landers Fork & 1 & High & Lodgepole Creek & 7 & Moderate & Bear Creek trib. to N.F. & 11 & Low \\
\hline N.F. Blackfoot R. & 1 & High & Sucker Creek & 7 & Moderate & Burnt Bridge Creek & 11 & Low \\
\hline Poorman Creek & 1 & High & Union Creek & 7 & Moderate & Gallagher Creek & 11 & Low \\
\hline Cottonwood Cr. (R.M.43) & 2 & High & West Twin Creek & 7 & Moderate & Humbug Creek & 11 & Low \\
\hline Monture Creek & 2 & High & Wilson Creek & 7 & Moderate & Shingle Mill Creek & 11 & Low \\
\hline Rock Creek & 2 & High & Blackfoot River 5 & 8 & Moderate & Clear Creek & 12 & Low \\
\hline Beaver Creek & 3 & High & Fish Creek & 8 & Moderate & Gleason Creek & 12 & Low \\
\hline Belmont Creek & 3 & High & Hogum Creek & 8 & Moderate & Indian Creek & 12 & Low \\
\hline Dick Creek & 3 & High & Nevada Cr.(upper) & 8 & Moderate & Frazier Creek, NF & 13 & Low \\
\hline Blackfoot River 2 & 4 & High & Pearson Creek & 8 & Moderate & McDermott Creek & 13 & Low \\
\hline Blackfoot River 4 & 4 & High & Warm Springs Cr. & 8 & Moderate & Smith Creek & 13 & Low \\
\hline Blanchard Creek & 4 & High & Willow Cr. (upper) & 8 & Moderate & Chimney Cr. (Nevada) & 14 & Low \\
\hline Dunham Creek & 4 & High & Ashby Creek & 9 & Moderate & & & \\
\hline Elk Creek & 4 & High & Buffalo Gulch & 9 & Moderate & & & \\
\hline Gold Creek & 4 & High & California Gulch & 9 & Moderate & & & \\
\hline Gold Creek, W,F & 4 & High & Camas Creek & 9 & Moderate & & & \\
\hline Kleinschmidt $\mathrm{Cr}$. & 4 & High & Chamberlain EF & 9 & Moderate & & & \\
\hline Spring Creek (N.F.) & 4 & High & Chamberlain WF & 9 & Moderate & & & \\
\hline Warren Creek & 4 & High & Chicken Creek & 9 & Moderate & & & \\
\hline Willow Cr. (lower) & 4 & High & Chimney Cr. (Douglas) & 9 & Moderate & & & \\
\hline Blackfoot River 1 & 5 & High & Cottonwood Cr. (Nev.) & 9 & Moderate & & & \\
\hline Copper Creek & 5 & High & Jacobsen Spring Creek & 9 & Moderate & & & \\
\hline Hoyt Creek & 5 & High & Jefferson Creek & 9 & Moderate & & & \\
\hline Salmon Creek & 5 & High & Moose Creek & 9 & Moderate & & & \\
\hline Snowbank Creek & 5 & High & Murray Creek & 9 & Moderate & & & \\
\hline Spring Cr.(Cottonwood) & 5 & High & Seven up Pete $\mathrm{Cr}$. & 9 & Moderate & & & \\
\hline Yourname Creek & 5 & High & Stonewall Creek & 9 & Moderate & & & \\
\hline Alice Creek & 6 & High & Washington Creek & 9 & Moderate & & & \\
\hline Arrastra Creek & 6 & High & Arkansas Creek & 10 & Low & & & \\
\hline Blackfoot River 4 & 6 & High & Bear Creek (R.M.37.5) & 10 & Low & & & \\
\hline Lincoln Spring Cr. & 6 & High & Black Bear Creek & 10 & Low & & & \\
\hline McCabe Creek & 6 & High & Blackfoot River 6 & 10 & Low & & & \\
\hline McElwain Creek & 6 & High & Finn Creek & 10 & Low & & & \\
\hline Nevada Spring Cr. & 6 & High & Frazier Creek & 10 & Low & & & \\
\hline Saurekraut Creek & 6 & High & Game Creek & 10 & Low & & & \\
\hline Shanley Creek & 6 & High & Grantier Spring Cr. & 10 & Low & & & \\
\hline Wales Creek & 6 & High & Halfway Creek & 10 & Low & & & \\
\hline Wales Spring Creek & 6 & High & Little Moose Creek & 10 & Low & & & \\
\hline Wasson Creek & 6 & High & Mitchell Creek & 10 & Low & & & \\
\hline Bear Creek (R.M.12.2) & 7 & Moderate & Nevada Cr. (lower) & 10 & Low & & & \\
\hline Chamberlain Creek & 7 & Moderate & Sheep Creek & 10 & Low & & & \\
\hline Clearwater River & 7 & Moderate & Strickland Creek & 10 & Low & & & \\
\hline Douglas Creek & 7 & Moderate & Sturgeon Creek & 10 & Low & & & \\
\hline Dry Creek & 7 & Moderate & Ward Creek & 10 & Low & & & \\
\hline East Twin Creek & 7 & Moderate & Warren Creek,Doney Lak & 10 & Low & & & \\
\hline Johnson Creek & 7 & Moderate & Washoe Creek & 10 & Low & & & \\
\hline Keep Cool Creek & 7 & Moderate & Bartlett Creek & 11 & Low & & & \\
\hline Little Fish Creek & 7 & Moderate & Basin Spring Creek & 11 & Low & & & \\
\hline
\end{tabular}


Exhibit D: Table 9. Water bodies sorted by native species priority.

\begin{tabular}{|c|c|c|c|c|c|c|c|c|}
\hline Stream Name & $\begin{array}{c}\text { Native Species } \\
\text { Ranking }\end{array}$ & Prioirty & Stream Name & $\begin{array}{c}\text { Native Species } \\
\text { Ranking }\end{array}$ & Priority & Stream Name & $\begin{array}{c}\text { Native Species } \\
\text { Ranking }\end{array}$ & Priority \\
\hline Belmont Creek & 1 & High & Lincoln Spring $\mathrm{Cr}$. & 5 & Moderate & Wilson Creek & 6 & Low \\
\hline Copper Creek & 1 & High & Little Fish Creek & 5 & Moderate & Black Bear Creek & 7 & Low \\
\hline Cottonwood Cr. (R.M.43) & 1 & High & Little Moose Creek & 5 & Moderate & Finn Creek & 7 & Low \\
\hline Dunham Creek & 1 & High & McDermott Creek & 5 & Moderate & Halfway Creek & 7 & Low \\
\hline Gold Creek & 1 & High & Moose Creek & 5 & Moderate & Nevada Cr. (lower) & 7 & Low \\
\hline Gold Creek, W,F & 1 & High & Nevada Spring $\mathrm{Cr}$. & 5 & Moderate & Sheep Creek & 7 & Low \\
\hline Landers Fork & 1 & High & Pearson Creek & 5 & Moderate & Strickland Creek & 7 & Low \\
\hline Monture Creek & 1 & High & Seven up Pete $\mathrm{Cr}$. & 5 & Moderate & Sturgeon Creek & 7 & Low \\
\hline N.F. Blackfoot R. & 1 & High & Shanley Creek & 5 & Moderate & Ward Creek & 7 & Low \\
\hline Alice Creek & 2 & High & Wales Creek & 5 & Moderate & & & \\
\hline Arrastra Creek & 2 & High & Wales Spring Creek & 5 & Moderate & & & \\
\hline Blackfoot River 5 & 2 & High & Warren Creek & 5 & Moderate & & & \\
\hline Blackfoot River 6 & 2 & High & Wasson Creek & 5 & Moderate & & & \\
\hline Lodgepole Creek & 2 & High & Willow Cr. (lower) & 5 & Moderate & & & \\
\hline Poorman Creek & 2 & High & Youmame Creek & 5 & Moderate & & & \\
\hline Dry Creek & 3 & High & Arkansas Creek & 6 & Low & & & \\
\hline Kleinschmidt $\mathrm{Cr}$. & 3 & High & Ashby Creek & 6 & Low & & & \\
\hline Nevada Cr.(upper) & 3 & High & Bartlett Creek & 6 & Low & & & \\
\hline Rock Creek & 3 & High & Buffalo Gulch & 6 & Low & & & \\
\hline Salmon Creek & 3 & High & Bumt Bridge Creek & 6 & Low & & & \\
\hline Snowbank Creek & 3 & High & California Gulch & 6 & Low & & & \\
\hline Spring Creek (N.F.) & 3 & High & Camas Creek & 6 & Low & & & \\
\hline Bear Creek (RM.12.2) & 4 & High & Chicken Creek & 6 & Low & & & \\
\hline Beaver Creek & 4 & High & Chimney Cr. (Douglas) & 6 & Low & & & \\
\hline Blackfoot River 1 & 4 & High & Chimney Cr. (Nevada) & 6 & Low & & & \\
\hline Blackfoot River 2 & 4 & High & Clear Creek & 6 & Low & & & \\
\hline Blackfoot River 3 & 4 & High & Cottonwood Cr. (Nev.) & 6 & Low & & & \\
\hline Blackfoot River 4 & 4 & High & Douglas Creek & 6 & Low & & & \\
\hline Chamberlain Creek & 4 & High & Frazjer Creek & 6 & Low & & & \\
\hline Dick Creek & 4 & High & Frazier Creek, NF & 6 & Low & & & \\
\hline East Twin Creek & 4 & High & Gallagher Creek & 6 & Low & & & \\
\hline Grantier Spring Cr. & 4 & High & Game Creek & 6 & Low & & & \\
\hline Johnson Creek & 4 & High & Gleason Creek & 6 & Low & & & \\
\hline McCabe Creek & 4 & High & Humbug Creek & 6 & Low & & & \\
\hline Saurekraut Creek & 4 & High & Indian Creek & 6 & Low & & & \\
\hline Spring Cr.(Cottorwood) & 4 & High & Jacobsen Spring Creek & 6 & Low & & & \\
\hline West Twin Creek & 4 & High & Jefferson Creek & 6 & Low & & & \\
\hline Basin Spring Creek & 5 & Moderate & McElwain Creek & 6 & Low & & & \\
\hline Bear Creek trib. to N.F. & 5 & Moderate & Mitchell Creek & 6 & Low & & & \\
\hline Bear Creek (R.M.37.5) & 5 & Moderate & Murray Creek & 6 & Low & & & \\
\hline Blanchard Creek & 5 & Moderate & Shingle Mill Creek & 6 & Low & & & \\
\hline Chamberlain EF & 5 & Moderate & Smith Creek & 6 & Low & & & \\
\hline Chamberlain WF & 5 & Moderate & Stonewall Creek & 6 & Low & & & \\
\hline Clearwater River & 5 & Moderate & Sucker Creek & 6 & Low & & & \\
\hline Elk Creek & 5 & Moderate & Union Creek & 6 & Low & & & \\
\hline Fish Creek & 5 & Moderate & Warren Creek,Doney Lake th & 6 & Low & & & \\
\hline Hogum Creek & 5 & Moderate & Washington Creek & 6 & Low & & & \\
\hline Hoyt Creek & 5 & Moderate & Washoe Creek & 6 & Low & & & \\
\hline Keep Cool Creek & 5 & Moderate & Willow $C_{\text {r. }}$ (upper) & 6 & Low & & & \\
\hline
\end{tabular}


Exhibit D: Table 10. Dewatered streams sorted by biological priority.

\begin{tabular}{|c|c|c|c|c|c|}
\hline Stream Name & $\begin{array}{c}\text { Dewatered } \\
(\mathrm{H}, \mathrm{N}, \mathrm{B})\end{array}$ & $\begin{array}{c}\text { Biological } \\
\text { ranking }\end{array}$ & Stream Name & $\begin{array}{c}\text { Dewatered } \\
(\mathrm{H}, \mathrm{N}, \mathrm{B})\end{array}$ & $\begin{array}{c}\text { Biological } \\
\text { ranking }\end{array}$ \\
\hline N.F. Blackfoot R. & $\mathrm{B}$ & 1 & Frazier Creek & $\mathrm{H}$ & 10 \\
\hline Poorman Creek & $B$ & 1 & Nevada Cr. (lower) & $\mathrm{H}$ & 10 \\
\hline Landers Fork & $\mathrm{N}$ & 1 & Warren Creek,East Fork & $\mathrm{H}$ & 10 \\
\hline Cottonwood Cr. (R.M.43) & $\mathrm{B}$ & 2 & Ward Creek & $\bar{N}$ & 10 \\
\hline Rock Creek & $\mathrm{B}$ & 2 & Bear Creek trib. to N.F. & $\mathrm{B}$ & 11 \\
\hline Monture Creek & $\mathrm{N}$ & 2 & Humbug Creek & $B$ & 11 \\
\hline Dick Creek & $B$ & 3 & Burnt Bridge Creek & $\mathrm{H}$ & 11 \\
\hline Blackfoot River 6 & $\mathrm{~B}$ & 4 & Gallagher Creek & $\mathrm{H}$ & 11 \\
\hline Dunham Creek & $\mathrm{B}$ & 4 & Frazier Creek, NF & $\mathrm{H}$ & 13 \\
\hline Blanchard Creek & $\mathrm{H}$ & 4 & Chimney Cr. (Nevada) & $\mathrm{H}$ & 14 \\
\hline Elk Creek & $\mathrm{H}$ & 4 & \multirow{37}{*}{$\begin{array}{l}N=\text { natural dewatering } \\
H=\text { human dewatering } \\
B=\text { both }\end{array}$} & & \\
\hline Spring Creek (N.F.) & $\mathrm{H}$ & 4 & & & \\
\hline Warren Creek & $\mathrm{H}$ & 4 & & & \\
\hline Willow Cr. (lower) & $\mathrm{H}$ & 4 & & & \\
\hline Blackfoot River 3 & $\mathrm{H}$ & 5 & & & \\
\hline Hoyt Creek & $\mathrm{H}$ & 5 & & & \\
\hline Salmon Creek & $\mathrm{H}$ & 5 & & & \\
\hline Snowbank Creek & $\bar{H}$ & 5 & & & \\
\hline Spring Cr.(Cottonwood) & $\mathrm{H}$ & 5 & & & \\
\hline Yourname Creek & $\mathrm{H}$ & 5 & & & \\
\hline Blackfoot River 4 & $\mathrm{H}$ & 6 & & & \\
\hline Little Fish Creek & $\mathrm{H}$ & 6 & & & \\
\hline McCabe Creek & $\mathrm{H}$ & 6 & & & \\
\hline McElwain Creek & $\mathrm{H}$ & 6 & & & \\
\hline Shanley Creek & $\mathrm{H}$ & 6 & & & \\
\hline Wales Creek & $\mathrm{H}$ & 6 & & & \\
\hline Wasson Creek & $\mathrm{H}$ & 6 & & & \\
\hline Arrastra Creek & $\mathrm{N}$ & 6 & & & \\
\hline Chamberlain Creek & $\mathrm{H}$ & 7 & & & \\
\hline Clearwater River & $\mathrm{H}$ & 7 & & & \\
\hline Douglas Creek & $\mathrm{H}$ & 7 & & & \\
\hline Keep Cool Creek & $\mathrm{H}$ & 7 & & & \\
\hline Sucker Creek & $\mathrm{H}$ & 7 & & & \\
\hline Union Creek & $\mathrm{H}$ & 7 & & & \\
\hline Wilson Creek & $\mathrm{H}$ & 7 & & & \\
\hline Dry Creek & $\mathrm{N}$ & 7 & & & \\
\hline Fish Creek & $\mathrm{H}$ & 8 & & & \\
\hline Warm Springs Cr. & $\mathrm{H}$ & 8 & & & \\
\hline Nevada Cr.(upper) & $\mathrm{N}$ & 8 & & & \\
\hline Stonewall Creek & $\mathrm{B}$ & 9 & & & \\
\hline Ashby Creek & $\mathrm{H}$ & 9 & & & \\
\hline Chimney Cr. (Douglas) & $\mathrm{H}$ & 9 & & & \\
\hline Cottonwood Cr. (Nev.) & $\mathrm{H}$ & 9 & & & \\
\hline Jefferson Creek & $\mathrm{H}$ & 9 & & & \\
\hline Murray Creek & $\mathrm{H}$ & 9 & & & \\
\hline Washington Creek & $\mathrm{H}$ & 9 & & & \\
\hline Arkansas Creek & $\mathrm{H}$ & 10 & & & \\
\hline
\end{tabular}


Exhibit D: Table 11. Dewatered stream list for the Blackfoot River Watershed.

\begin{tabular}{|c|c|c|c|c|}
\hline Stream Name & Affected Length & Natural & Human & Both \\
\hline Arkansas Creek & 2 & & 2 & \\
\hline Ashby Creek & 2 & & 2 & \\
\hline Arrastra Creek (sm 4.5-2.0) & 2.5 & 2.5 & & \\
\hline Bear Creek (North Fork) & 1 & 1 & 1 & $x$ \\
\hline Blackfoot River (Seven-Up Pete-Poorman Creek) & 11 & 11 & 3 & $x$ \\
\hline Blackfoot River $(54.1-84.9)$ & 30.8 & & 30.8 & \\
\hline Blanchard Creek & 1.2 & & 1.2 & \\
\hline Burnt Bridge Creek & 1 & & 1 & \\
\hline Chamberlain Creek & 1 & & 1 & \\
\hline Chimney Creek (Nevada Creek) & 0.5 & & 0.5 & \\
\hline Chimney Creek (Douglas Creek) & 3.5 & & 3.5 & \\
\hline Clearwater River & 3.5 & & 3.5 & \\
\hline Copper Creek & 1 & 1 & & \\
\hline Cottonwood Creek rm 43.0 (sm 10.0-4.4) & 5.6 & 2.8 & 2.8 & $x$ \\
\hline Cottonwood Creek (Douglas Creek) & 5 & & 5 & \\
\hline Dick Creek (sm 3.5-6.0) & 2.5 & 2.5 & 2.5 & $x$ \\
\hline Douglas Creek & 14 & & 14 & \\
\hline Dry Creek (trib to Rock Creek) & 0.5 & 0.5 & & \\
\hline Dry Fork (trib to North Fork) & 2 & 2 & & \\
\hline Dunham Creek & 5 & 4 & 1 & $x$ \\
\hline Elk Creek & 3 & & 3 & \\
\hline Fish Creek & 0.3 & & 0.3 & \\
\hline Frazier Creek & 1.5 & & 1.5 & \\
\hline Frazier Creek, North Fork & 0.5 & & 0.5 & \\
\hline Gallagher Creek & 3 & & 3 & \\
\hline Hoyt Creek & 1 & & 1 & \\
\hline Humbug Creek & 1 & 1 & & \\
\hline Jefferson Creek & 1 & & 1 & \\
\hline Keep Cool & 2 & & 2 & \\
\hline Landers Fork (3.6-4.5) & 1 & 1 & & \\
\hline McCabe Creek & 2 & & 2 & \\
\hline McElwain Creek & 1 & & 1 & \\
\hline Monture Creek (12.0-15.0) & 3 & 3 & & \\
\hline Murray Creek & 3 & 3 & & \\
\hline Nevada Creek (sm 31.7-6.4) & 25.3 & & 25.3 & \\
\hline Nevada Creek (sm 40.0-34) & 6 & & 6 & \\
\hline North Fork of Blackfoot River (rm 12.0-6.2) & 5.8 & 5.8 & 5.8 & $\mathbf{x}$ \\
\hline Pearson Creek & 2 & 2 & & \\
\hline Poorman Creek & 2 & 2 & 2 & $x$ \\
\hline Rock Creek (1.4-7.0) & 5.6 & 5.6 & 5.6 & $\mathbf{x}$ \\
\hline Shanley Creek & 1.6 & & 1.6 & \\
\hline Spring Creek (trib to Cottonwood Creek) & 1 & & 1 & \\
\hline Spring Creek (trib to North Fork) & 2.5 & & 2.5 & \\
\hline Snowbank Creek & 0.4 & & 0.4 & \\
\hline Stonewall Creek & 2 & 1 & 1 & $x$ \\
\hline Sucker Creek & 1 & & 1 & \\
\hline Union Creek (sm 7.0-0.5) & 6.5 & & 6.5 & \\
\hline Wales Creek & 1.9 & & 1.9 & \\
\hline Warm Springs Creek & 1 & & 1 & \\
\hline Warren Creek & 6 & & 6 & \\
\hline Washington Creek (Section 24 and 26 ) & 1 & & 1 & \\
\hline Wasson Creek & 2 & & 2 & \\
\hline Willow Creek (lower) & 2 & & 2 & \\
\hline Wilson Creek & 0.8 & & 0.8 & \\
\hline Yourname Creek & 1 & & 1 & \\
\hline Totals & 196.3 & 51.7 & 164.5 & \\
\hline
\end{tabular}




